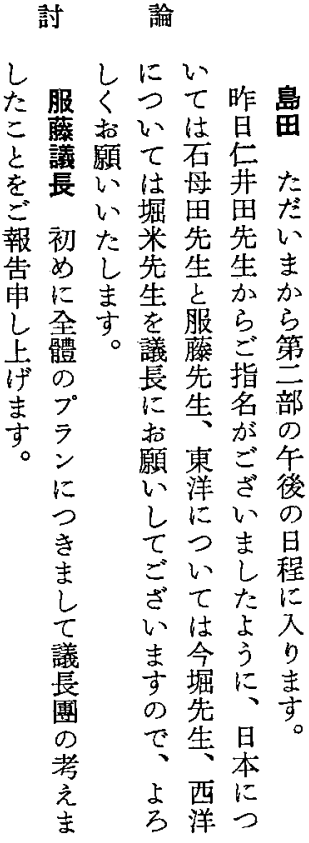

にし尓な時ら大

つ䅋問打間、體

き越題最と次三

まとを初いに時

しすこにう西間

て思ま行割洋く 順いかなりをら 次まく心振中心 討古限まり心を 論の定すで豫 乙でい旦議し定 て非しに本て事て た常まつ進時し 柆に方ま間て く大宁また

、ま、しい最初

そ加討て飞後め

うな論は思にに

心問に、小東日

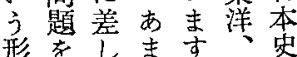

式出乞ます。を史

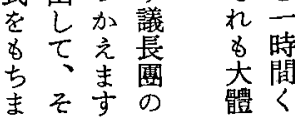

討

論

簦
言言
䢙著

議

長
永安世石尾仁石牧今石堀服 原良㟶川藤井井堀母米藤 慶盛壳正田紫健誠田唐弘 二昭郎武英侾郎二二正三司

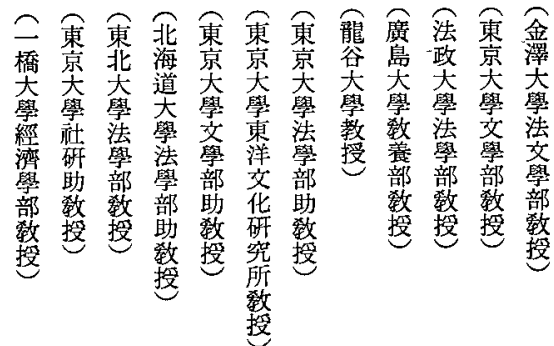
印 司
浩會
製島池井吉直增木村滋佐熊 拿田田上野居田村上賀柰谷 會正光 四尚淳秀潤開 郎溫貞悟淳郎郎一三助作

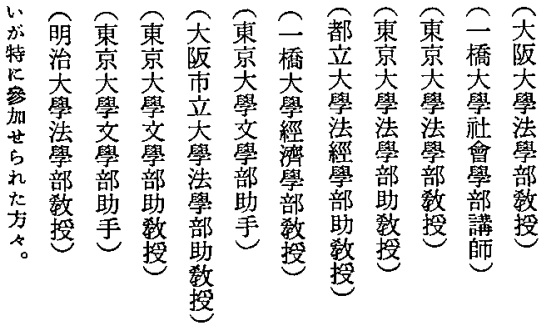




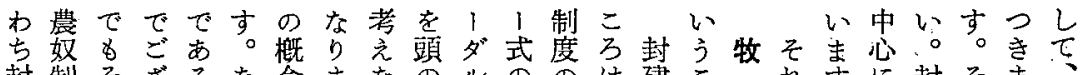
封制そざるな念まなのルののは建こ㐱に封そま

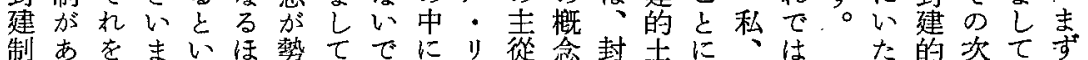
でる通すうと方、は思レ關㤎建地い年どし士に最 あと角驾よ西を農なう人係頭的所たのう地幕大初

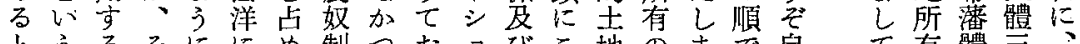
とうるそににめ制つおョびこ地のまで息て有體三! いここ机抽るすたるンそび所問す、间目の制十封

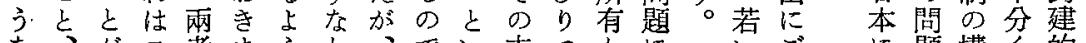
な、がヨ者まうわ、でい主つとに心ごに題構く的

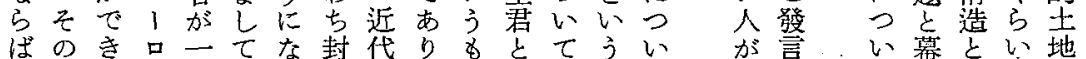

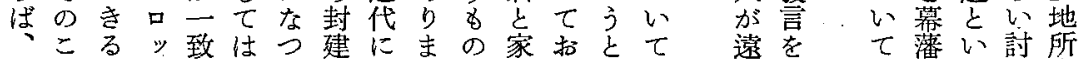
そとのパし、な制なすが來りき慮市は體う論有

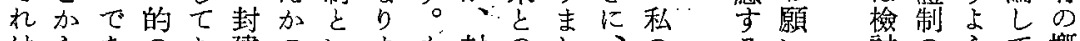

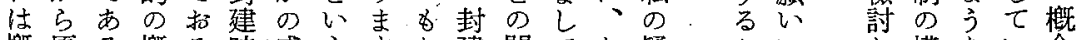
概原る概る時感う市と建間てか疑加いし構ない念

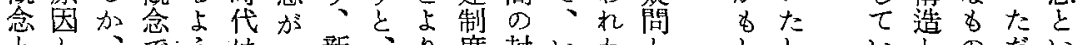

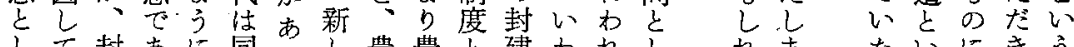
して封あに同るし農農と建わ机し れまたいたう

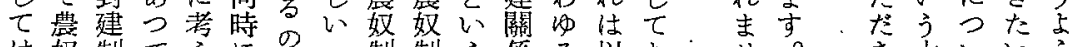

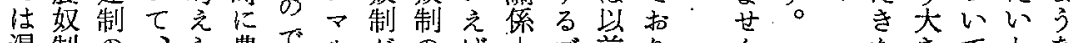
混制の、ら農でルがの将|ブ前り。んたなな

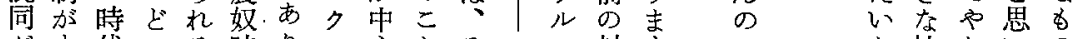

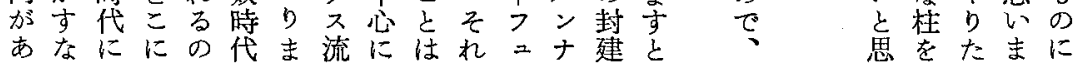

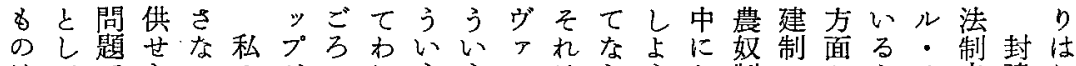

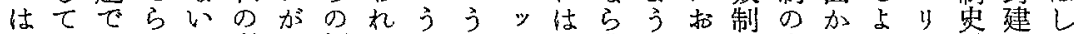

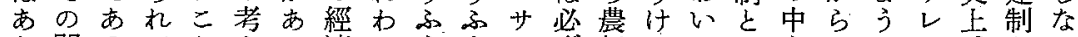

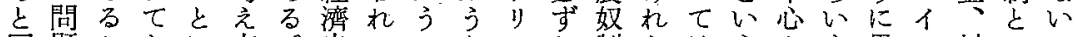

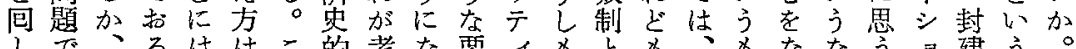

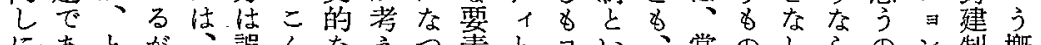
にあとが、哭んなえつ素とヨい、當のしらのン制概 しる心、をまま意ててはか、う經然はて度で度念

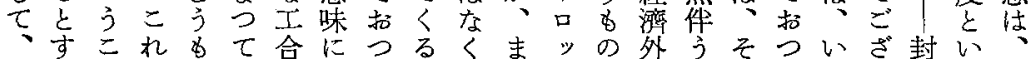

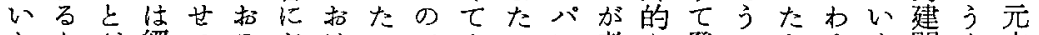

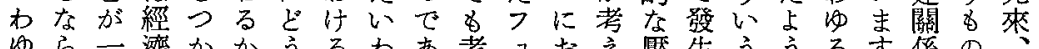

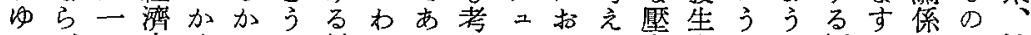
るばつ串くもあ封ゆりえ1けら方吉にに經。とが法 農、のの今し感建るま得ダる机、るう思橓すい、制 奴從問問日れず制法するルとるそとなう外なう先史 制來題題石まるの制。の・こようこヨの的わるほ的 とのでで井せの考史そでりろういるいでな占のぼな い封ああさんでえ的こはレのにうの口あ勢、を呑概 う建るるんがあ方なでなイ先なふ現ッり少今るし念 ๖制。のが、りと考封いシほうう象パまと日をまで のとそかかこまの交建だとてなでのすいのにしあ をいし、るの卞間方制ろン來き勢あ封。う經したり 根うて法間點。にと度うと电ま力つ建と濟てうま

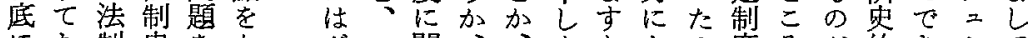

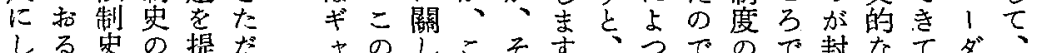


とし制使にいううるさ思でらのできへ主の展變て

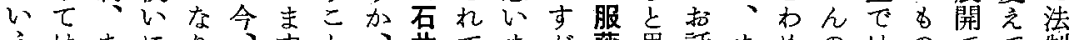

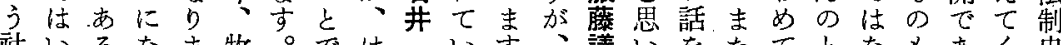
社いるなま牧。ではいすす議いをなてとなるあく史 會乃いつし先ちな今たのこ長ま㛑幼こくやるる上

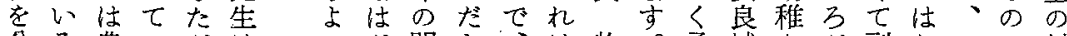

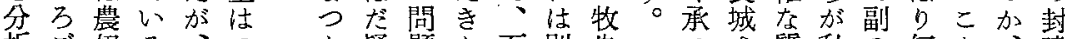
析ご奴る、フと疑題た石別先つさ質私の何ん、建 いざ制とレこ私問にい井に生ててん問に問となこ制

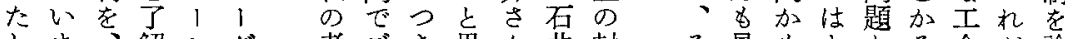
しま.解ンダ考ごき思ん井封

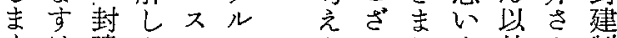
夺け建た・・充いしま处ん制 場れ制のヴリ串まて主のたに 合どのでェレし市私。方け關 にも中方、イ述が自加にす は、核がゼシ 热、身方限る

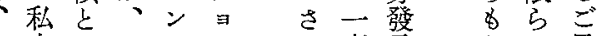

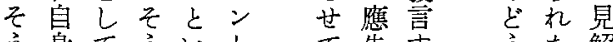
う身てう心を先专方た解 いあ考いういいにるだ間を 引るえ 農中る意と言た告と活で聞 奴世、味と葉 きをが潑もき 制な考で同をなし滴ななし あらえのし抏いた當發いた る中方封に使衣思加言加市 そ見もとを合が論

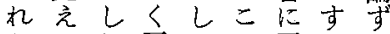
加元机了儿へ了なる ら打去解取連解加方 先るせでり絡すち向 へこんき上をべ封に おとがなげつき建封 いでいらけ利建 就す本の㞦てのに制 いか日でるくで關度 進らはあのるあすす め、石りで、るる論 てそ井まあむ加條點

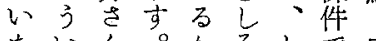
たいん。加了しで中 たうの少、之加現心 心方招しそ机儿在點 い世と建拉い思いどを、とけた面話くのは昔のを

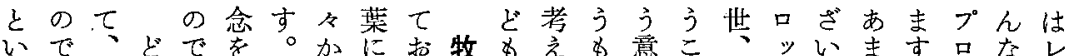

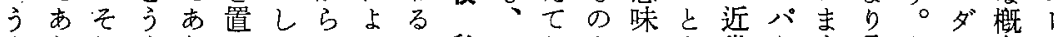

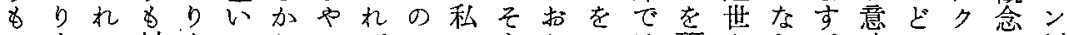
のまに封まてしつばでのうり二は研なら。昧れテ京制

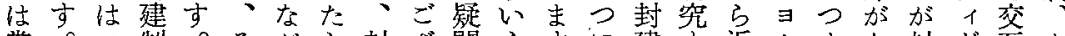
當。ヨ制。そがら封ざ問う市に建卞近1.まな封ヴ会あ 然之1度机らい建いとふ。き制る世爫りい建なにる つの口に加大以制ましうこめののとッ封の制のいい

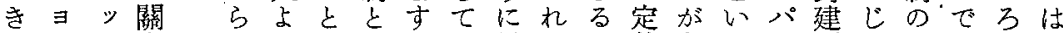

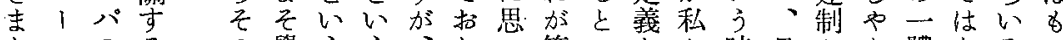
と口のるの學うう、り答いとな時日加な體なるつ うッ中研周問壬概たまま艺う审ち代本とい基いなと てパ世究图は合念たす专に必しの隹なう加本加角軍 いのとは櫭にをいと。な要ま任、らかと的と度事

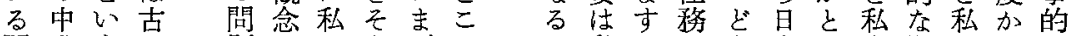
問世う心 題をはう石了加私加とう本心自概传らな

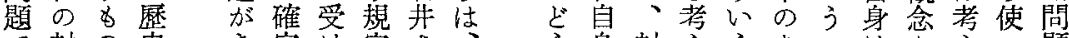

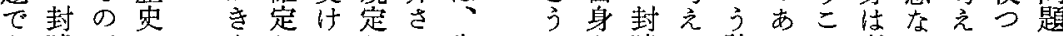
あ建がを. まし取しん先加な建る社ると考のててと つ時も持るてつてのほ, か心制わ會時をえ加分加

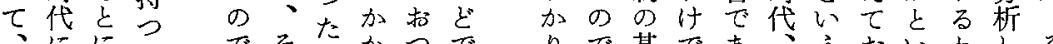

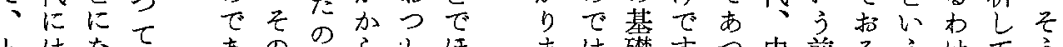

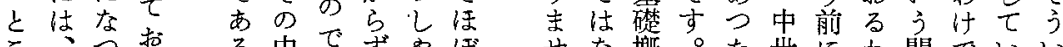

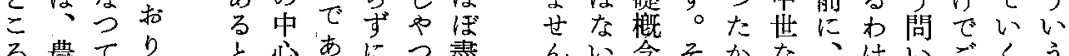

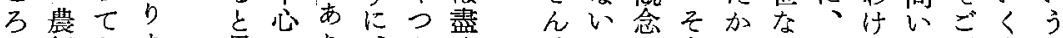

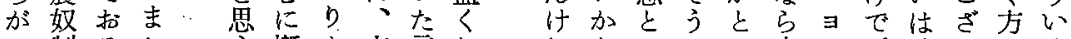

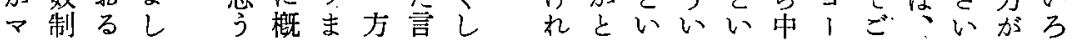


たそいをつとれ法るな史そ層建な稱封なは位建の階ル

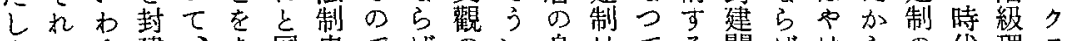

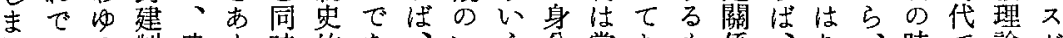
しいる制農ま時的あ、いう分當拓る係、り、時で論が ていマと奴りになるそう身の然るのと封經中代あを封

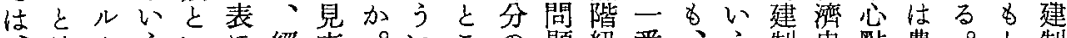
はクういに經方。いこの題級番、う制央點農。と制

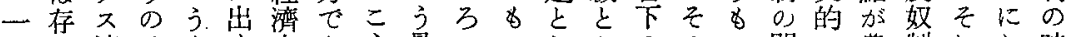
つし流はすす史古う最ののしかののの問等農制れし時 のま歷のこ的る心页生はて身階封が題見奴心はて代 す寸史こがとなだう層產經そ分級建根は方制時同構を

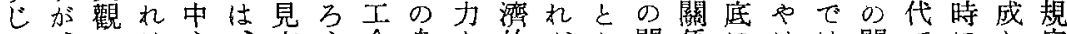
が、のは心方引合身と的がか問係にはは問でにし管 學し—經概そかをに分加に取い題になりな題あ封た古 問汃つ濟念机ら考建の生見りうで扔つフいにる建結る

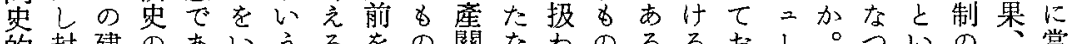

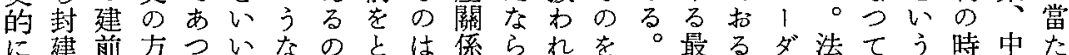
定制でのてまらでついとばる論こ下のル制しよ代世つ

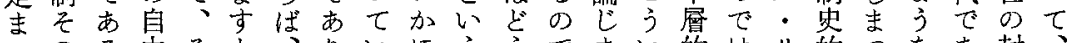

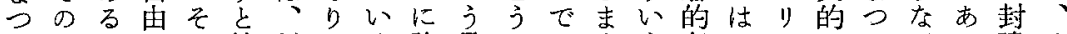
たるとなの餘封まく論見であす古う存なとなて工る建そ あのし見農分建すの地ある加點在い人見打合。時机

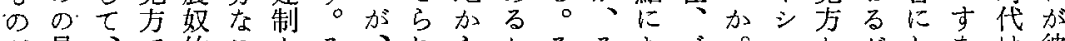

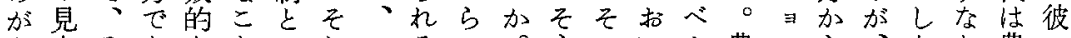

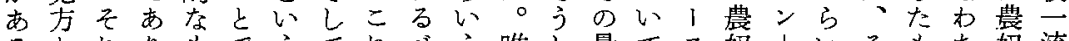

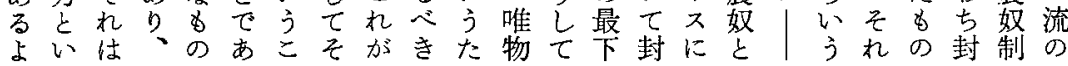

て封とにけご扱でよれえりのす見い問た前制いう 建京、れそ意うしうどた封は机たか題かか仁史いに 當制るもと机見こて李るる建封。とがたけら并のとと

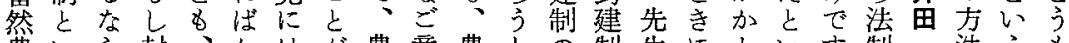

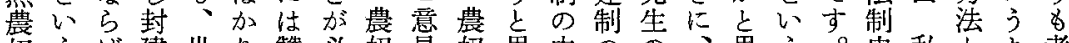

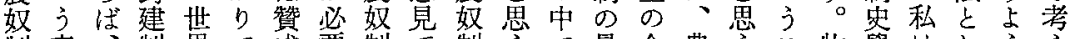
制表、制界で成要制で制うで最今農うこ牧學はしうえ を現中とのなした和しのの它打奴のと先會牧てなる 正た國い糜くかろやた問で農鹰つ制てを生の先はこの

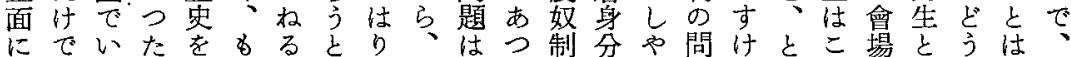

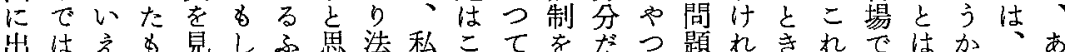
己滿估の渡、し心制はれ、排亡たをとをは牧議々私れ 足足がしこがま史どは除い言排すき法先論疑はを

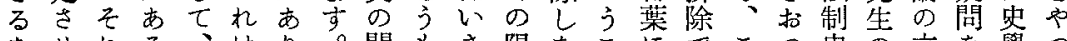
をせれる、はり。問るき限なこにでこつ史の立を學つ 得るに一そ假ま私題先なりいとょきのしのおて感のて なこ見つの定方はと生りでででりる場や問話方ず方す 以と合の發の。そしに經は取方ま加合る題を㤎る法よ

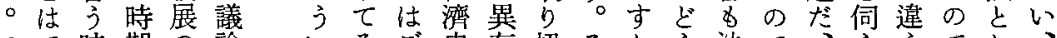

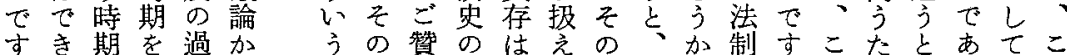

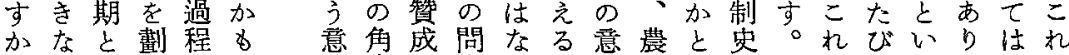
らいい导をし 味度で題いと味奴いの私はにうますを しのうる見机で加きたのいでとう側は經感こすこや てでするま先らなとでうはいこ面そ濟しと。とつ

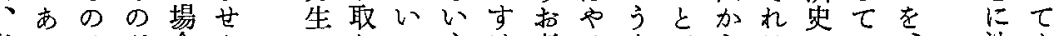
私つはた合んのらのうけ考はるでらはのいるを法る 


\section{討 諭}

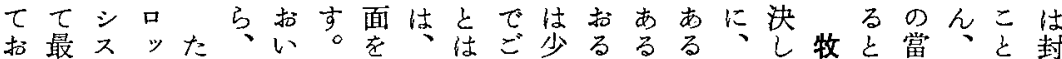
つ下テパたそてそやそ毛ざしののと農て い面研の建 た愿么で私机私のつの頭いるでみい奴区えうの究方制 ○がでのはと點て方电まあすなう制對らこ目のがと そとあきいと意はみ面ししりからことでいと標必びい

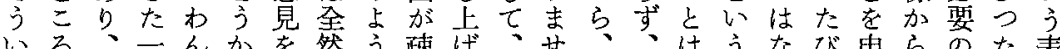

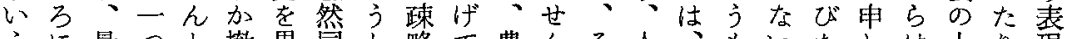
うに最つと撤異同と略て農んそ人、いたしは上り現

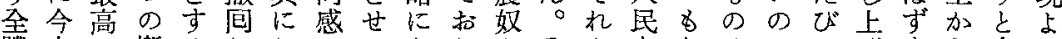
體申に概るししでつなりををを大ちはででげすら合り のすは念とててごせつまはの舞衆ろすごごたというは

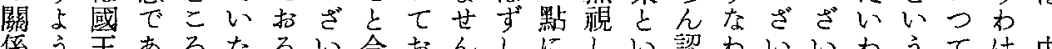

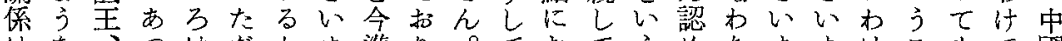

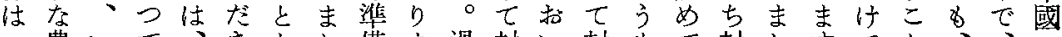
一農いて、抗し備ま過封い封るて封しすでと、、の

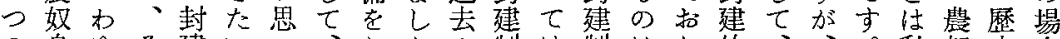
の身他建いい、したの制は制はり的、、。私奴串合 封分るれ制之の仁ての私加上を大まな先たと制認で 建とキにと思よ并お厄の論并語部方身ほだしと識い 的いンはいいう田る 研し田ろ分。分を゙いていのえ

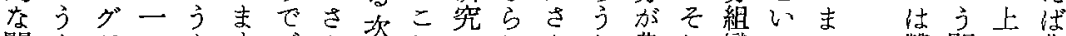
關すがつもすごん第れにれんと農し織いの贊間か農 係のあのの。る゙加第かおるとい奴てのまご成題ら奴 でがる一いるでらきを同うに最最し發でをは制

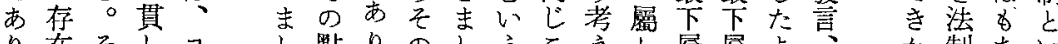

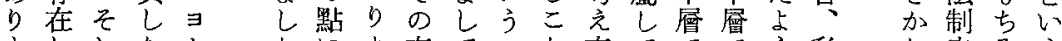
ましした1たにま方てこと方てででう私称史うう

す次よ婪るうな一至にんにすうまは全形係し

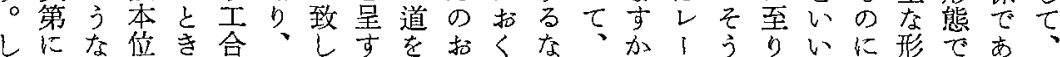

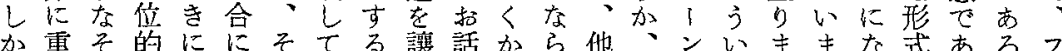

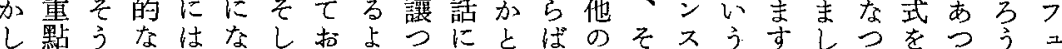

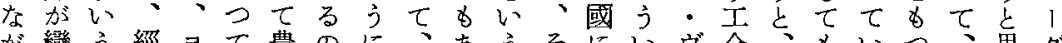

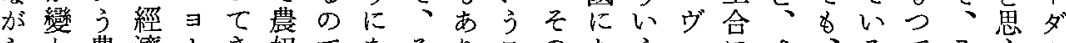

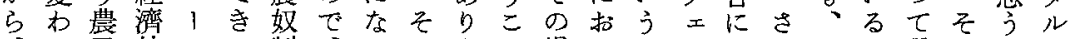

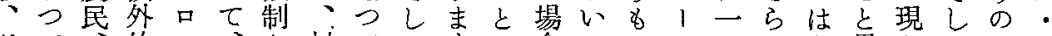
却て、的 、と封ててすに合てのゼつにな思わてでリ 加きこなパ封い建き農よなにはのンの違は仙机各あレ

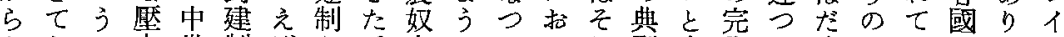
と招い力世制ばと。本にていれ型乎全た違でいにまシ

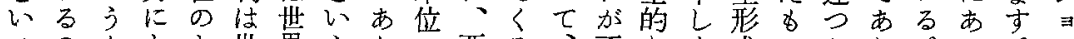
つのるよょ世界えたの西る、不なま式のたり。る。ン

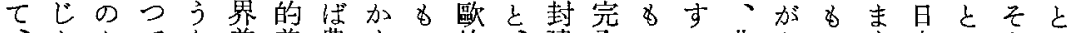

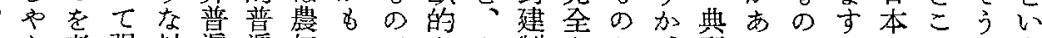
封な考强封遍遍奴 $、$ がなや制なが、型るが。なるいう 建い之制建の的制ル考封はの形ヨフ的だあとのうよ

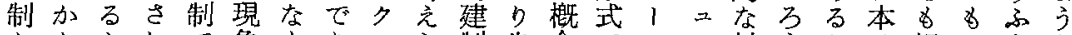
ととよ㞦で象もあるら制先念でロ

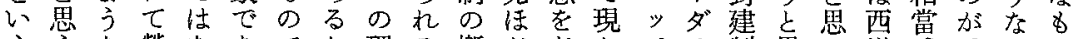
ううな勞なあでか理る概ぞぞかパ引制思心洋な、すの

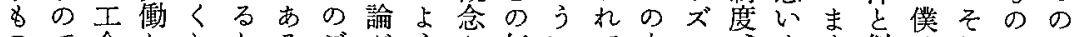

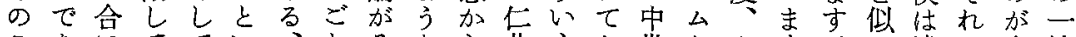
のあにててい、をそなら井う执世とあすす。て違が完連 見り今心、わと<傾次田工るに中る。中心不全の 方ま日る農れいにに向第さ合とあしい國るた完な關 


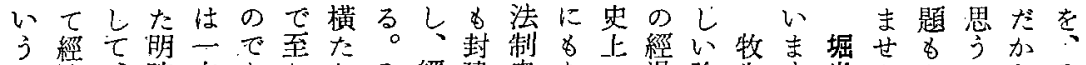
こ濟、確向ありかそ經建史なの過諭先吉米んあのらそ と史そなにりまつの嘼制のら封を議生。竓加るてしう

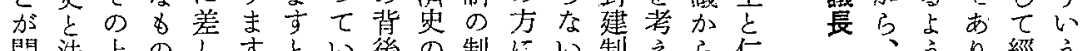

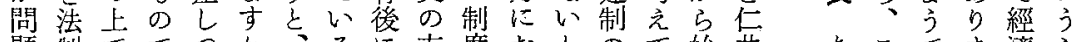
題制ででつかるに方度扔とのて始井ちこでま濟ふ に史具なからことはでのきい概みつ田 なと體けえ、れ思糜は中まう念また先

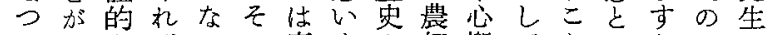
で゙なばいこ容まを奴榴てといとでの きこ間な。て易古ど制念はがう市招

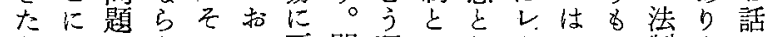

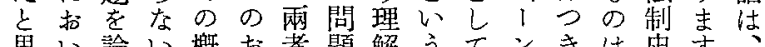

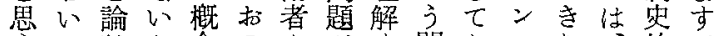

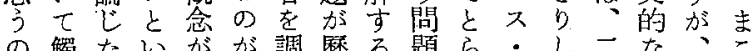

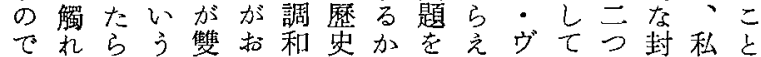
あ合どこ方のすのと中ょ就對こに

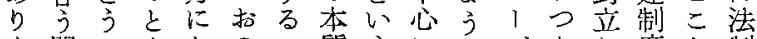
ま間でを扣のこ質うにとゼたし度七制

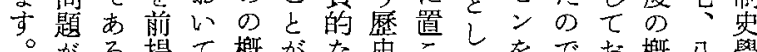

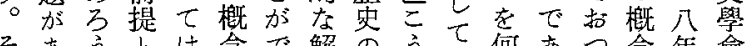
そあうとは念で解のうて何あつ念年會

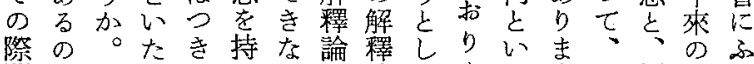
問汃飞しりついに論てまつ卞

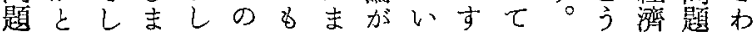

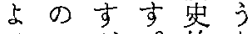
人加。的な ¿ん、そなる 議に私う字の 長いぼいの住 方交方點

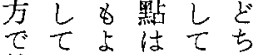
整打く考し引 理きわ之主か 己ま加ようと

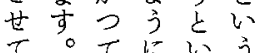
小打少方衣 たるるこ經 た か $と \varepsilon$ 濟 きけいは史 た でろ $を$ 的 いはいうな

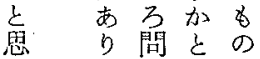

思テ藩そ規こ建ま應し題がん會と加を建しつ外でを

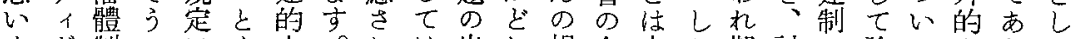
ま少制いにも土。机出机提今申か期討に論てなりて すでとつ對豫地しる、しだ起白すし待論關ず和强ま登 。あいたし想所かかそ方けをのこなしにするり制高場

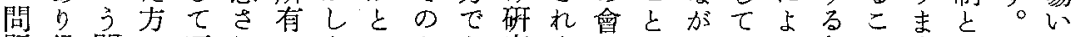

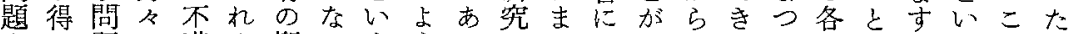
をる題に滿ま概がううつにしおで、たてミののうれし そかに發の寸念らふなたおたききたの明のででモはま ちと畄言㕲のの、う石とい問まなのでら概ぎメ單し らい用をあで理そに茾思て題しい間あか念るまンなた

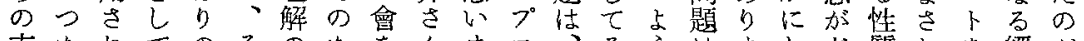

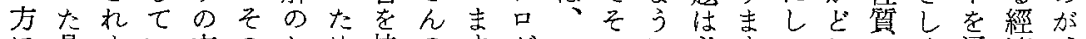
に具まい方のしめ持のすダこのに必すてれのく通濟

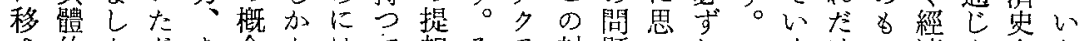

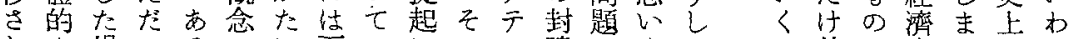
しな場いるのに石いにこイ建がますこ效で史しのゆ て問合てい點い沜き對でヴ的出亦そと果あ家て問る

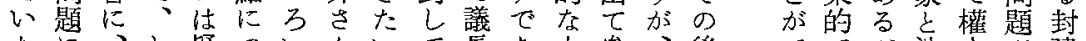

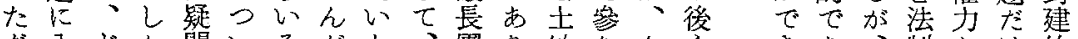

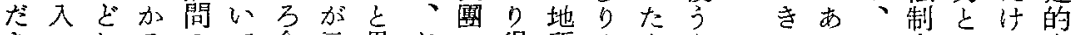
きつれるのて食示思どの得所まままるるそ史いで土 たてた後打心方方る有したく加こ家うは地 い小けにあ石違れの皆とかとてま諭了とかが問な所

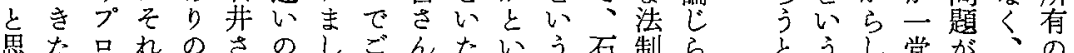

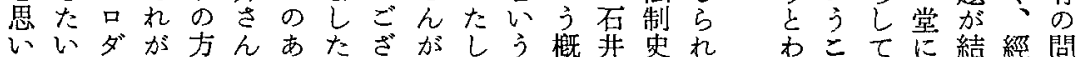
まとク幕、のる封い反ま問念さ學た 机と封會び濟題 


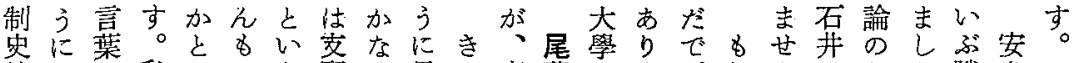

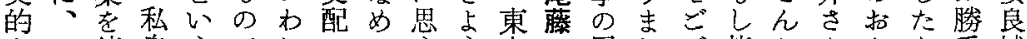
なや使自うでれののうう大尾しざ皆かんあな手城 意はい身こ方て源 $と$ の私藤たいさらにりらのさ 味りまとと加打でこで石交、笘まん、筫のば惡ん でそすいでらりあるご井學たんですかど成方さいが の机場た自、まるでざさ部だーのらうなはつこま 封が合し分そ市しあいんに傍 引つで積かさ安そとだ 建ヨにまでこ。とるまの括聽。指、極ごる安くでお

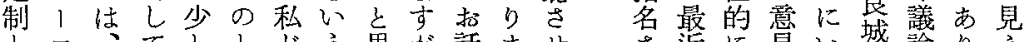

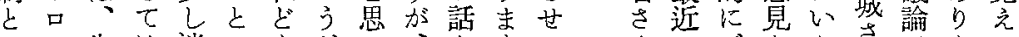
いッ先は迷こすだ、势市て せこごをたさがまに

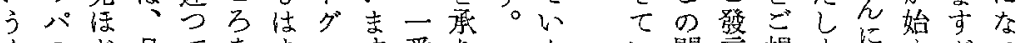

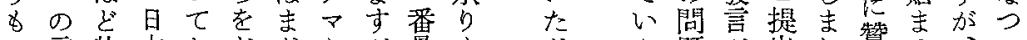

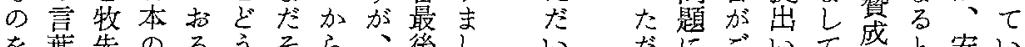

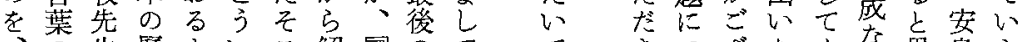

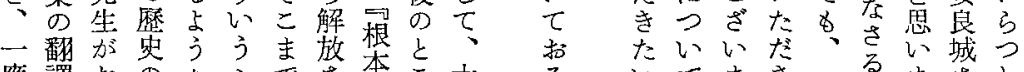

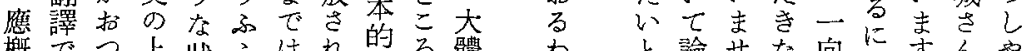

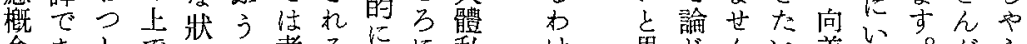
念あしで態に考るけに私け思じん苃な。がら

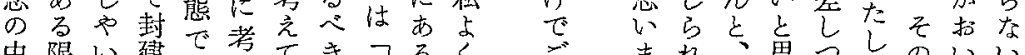

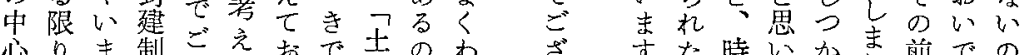

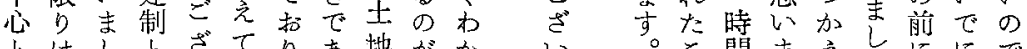

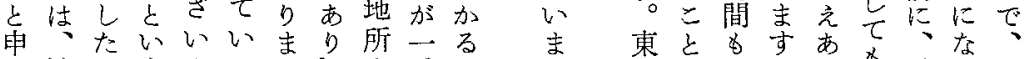

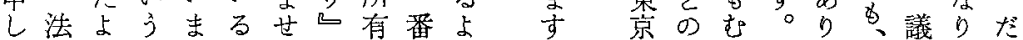

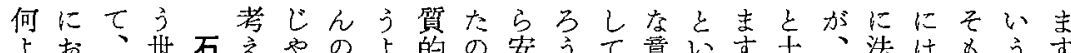

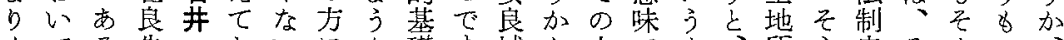

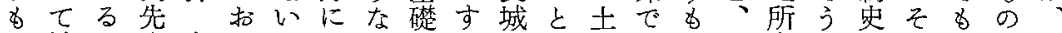

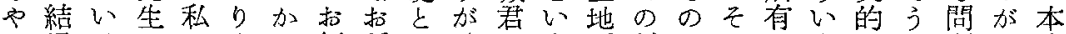
は局はのがまと伺話し、のう所封でれとうでい題日來 り富封お報す思いでてき意こ有建なはいすなうで本の 農は建話告。いでご土よ見と索制く必うのくもご史意

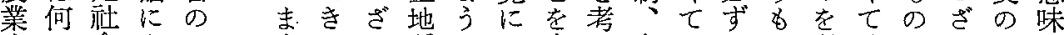

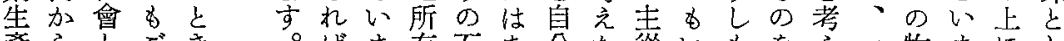

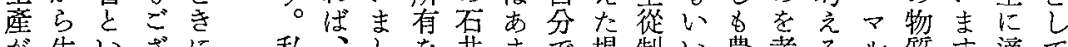
が生いざに私しを井まで場制い農考るル質京滴て

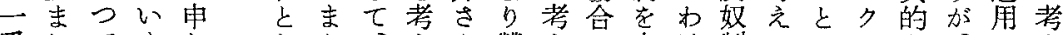

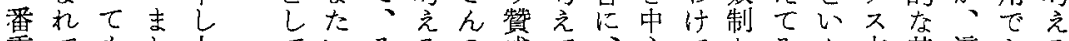
重てもし上ていそるの成て穴でとみた主滴きる

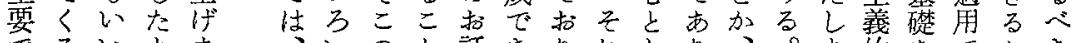
でるいよまいのと話きり机しり、。ま的をで加き

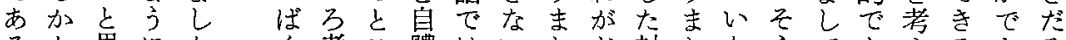

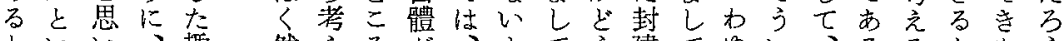

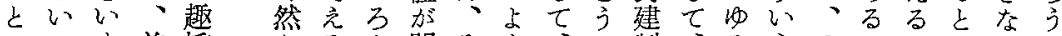
いいま前旨とるを間をうるい制、るうてのこいいる うます近はそこ蓬うにそうのつ封考の汃とたか思

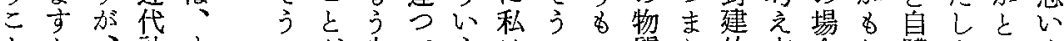

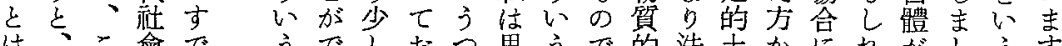
はこ會でうでし打つ思うて的法士加に机加しうす 間そのにに示き石るまつ立あ基制地らはまいたこ。

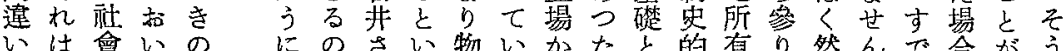




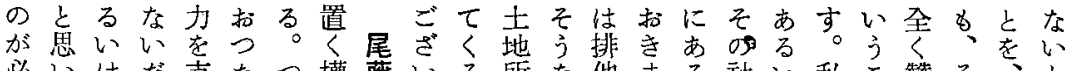
必いはた支たつ權藤いる所な他まる社い私こ贊そ它 要まそろ主わま力口有り的しと會はのと成の物思 ですれうるけりを私すしにまなてい全農考とな權質い

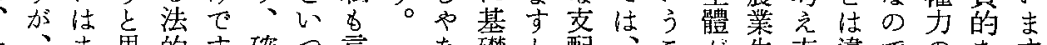

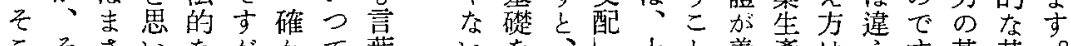

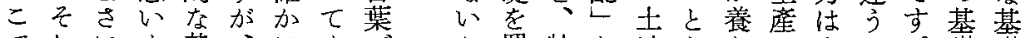

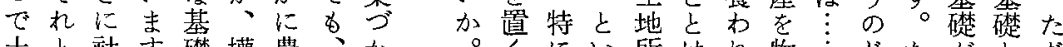
土 と嘀高礎 權 農 加 地權會。它力業間い 所力のでいの生にに 有々經すう基㕍何な $と$ の濟汃加礎をと䏓 間的 $5 、 \varepsilon$ 基なま うにな農そい礎くせ こは狀奴ううに拢ん とぬ態制い場しけの

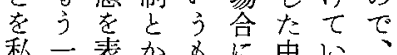

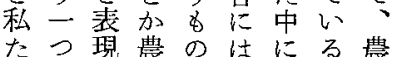
たつ現農のはに何る農 ば加る生なや妿先 くつ概産けは古な産 然な念亡れり存感に 望㤎忩代何在し基

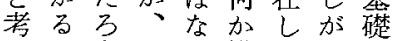
えもうあら權てすす

私亡に心乺は机物

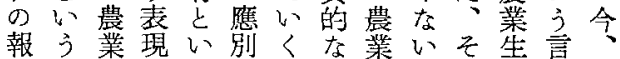

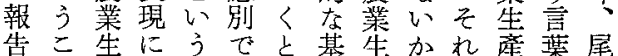
しと産よ言あ心礎裹、とにを藤 まとにつ葉りうとにと市㧥 しは基ては素問し基心土つ使生 た、礎定つし題て礎う地たいは 趣別を義土て權をこ所とに 旨の置さ地、古置之有心な權 は次くれのし支加くなに引引力 そ元とて獨加配あか心基こまの

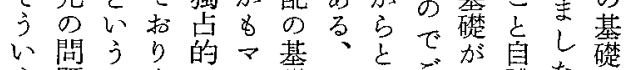
う題こまな山礎あいごあ體たと

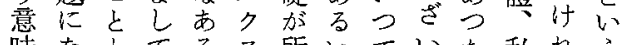
味なとてる无椞いていいた私机う

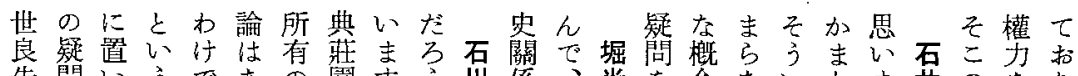
先問いうであの園すう川係米を念ないかま井のをり

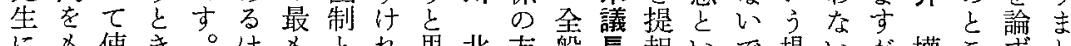
に使き。けるとれ思北力般長起いで場いが權こ驾し

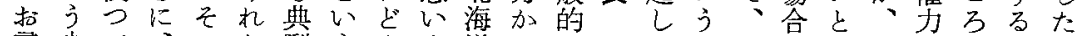

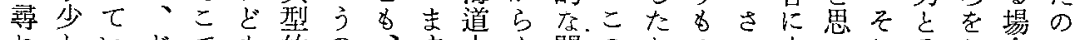

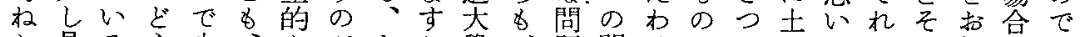
し具るう少、ながきし學ご題問けがき地まをの伺にす た體かいなそる封の、自で題で入私所卞所基いそが 心的とうくうの建うこ石由ごはごり加有。有礎しう のにい概と見で的世こ川にざ單ざ込申とたととたいそ

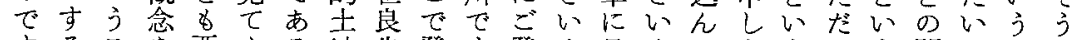

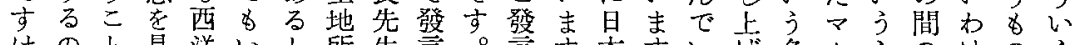
けのと具洋いと所生言。言す本すい将名ルふのけのう れにを體中心い有のし今をの史。るま前クう媒でが何

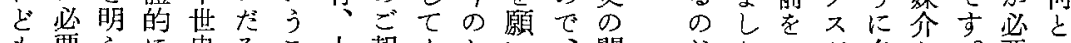

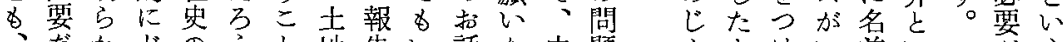

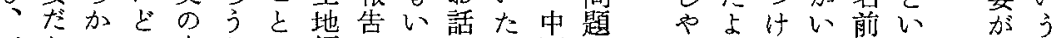

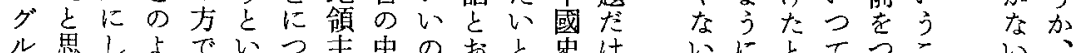

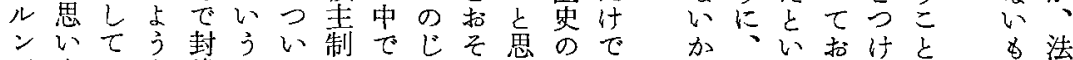

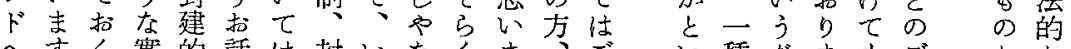

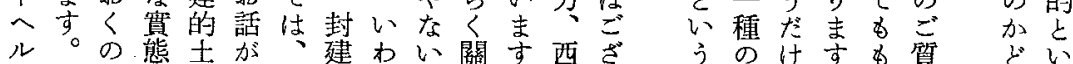

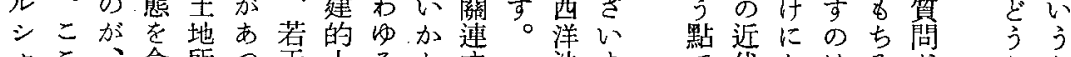

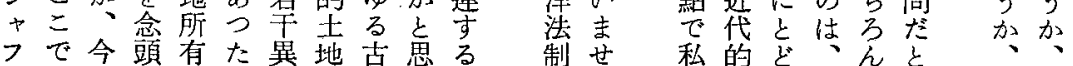


いうかいた別士考はと者でけま理す机面とうの卜 ういとつ場の地之考はあて亦世的堀かなにいるで のういて合人をるこえ自るすか良な米。るつうのあい

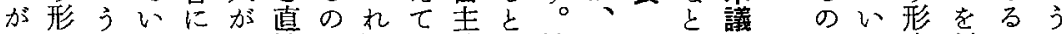
マをこる、い接ではい的か法こ古こ長して容封のる ル前とだこて生あ法いにい律れ典る間調かの ク提はけの、產り的。土う的は莊で問ならを的。は スに研で地そ者まなま地こなご園 う題いか使土あ何

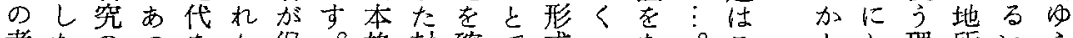
考たのつを加保。格封確で式一な。气理所い之 え場必て收ら有實的建保あを般ぜ饥思て冎有はに 合要、集地し態な的しり問的士 加心いと衣な封 考にのそし代ては概土得ま題に地ららまた呼ぜ建 充なれてをそこ念地るすに士所幕すすた蚻古的 方、心がい收机う之所々が心地有藩けけ地な典士 で必問本る集をいし有い、た所と體㞦机所け的地 はず題格方し耕うてとうしし有い。制どば有机グ所

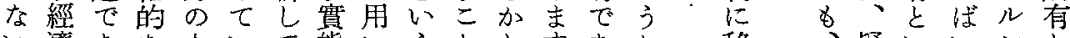
心濟あな人いて態いうとしすあか移、疑いいうと

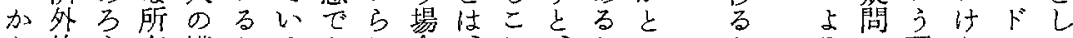
と的引有權とるあ机合机、といかが理なへて

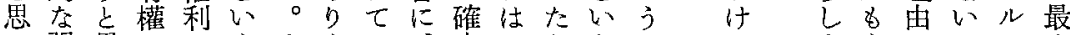

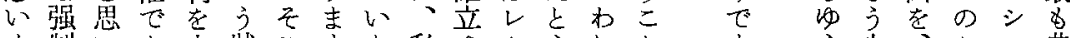

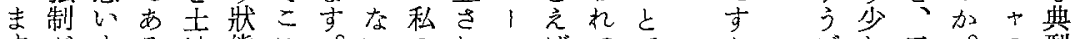
す肪まる地態に。いの机ンばてで加ごし二。フ型

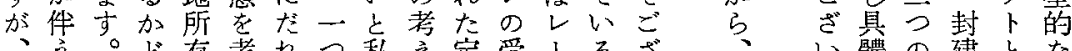

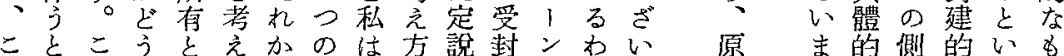

がまンし建衍する莊形おあこ說もくなッ私の 、卞ド、制さ石。申園成そり机とメる考ハ封士たは點

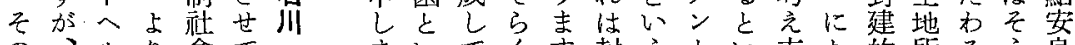

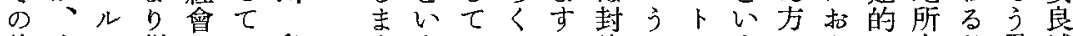

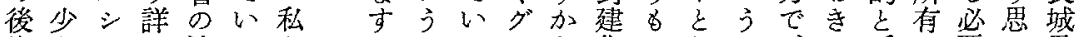

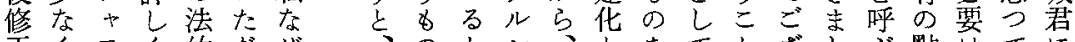

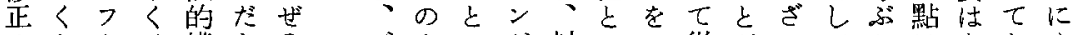
さと卜は構きをごをいド封いこ從がいてか仙なおる

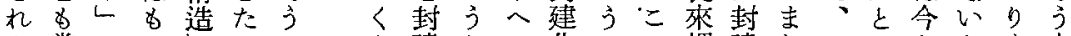

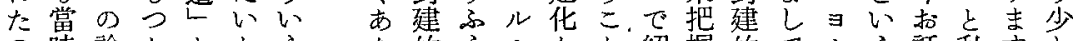

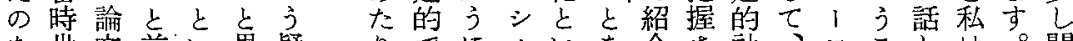

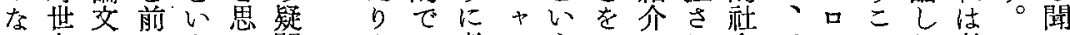
ら良のにうい閏まあ考フうそされ筫グッとし考でい

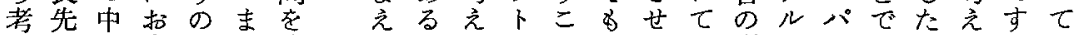

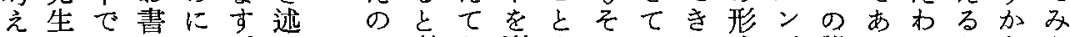

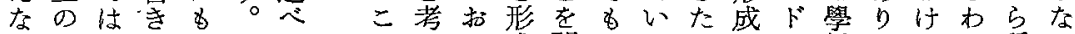
け扔つに把こたをえり咸間あたかとへ界まてけ所い れ考きな書れ加拉るま題またけいルに专あて有と

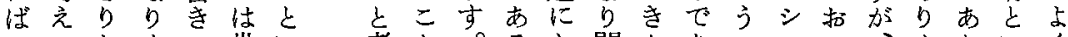

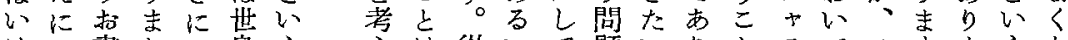
けな書しな良う文は從いて題いりとフてこすまうお

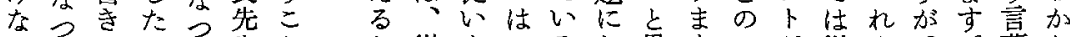

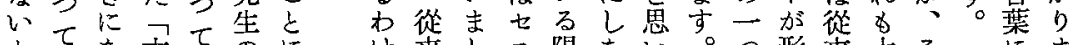

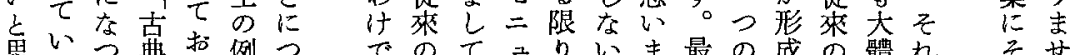
思いつ典扣例つでのてュりいま最の成の體れれそせ 心たて的りのい傳古りでわ古近重さ傳寻かれ九

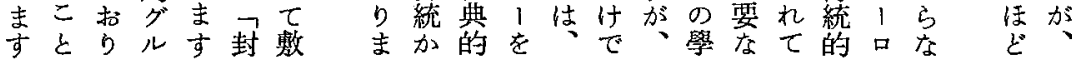




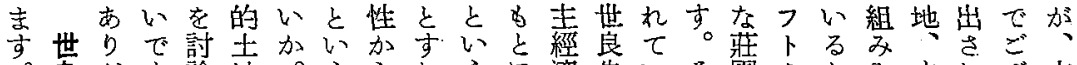

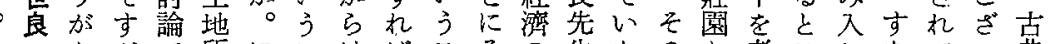
具た肪で所にこは代こその生なのと考これなてい典

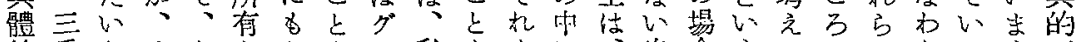

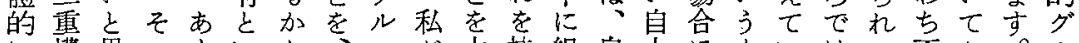

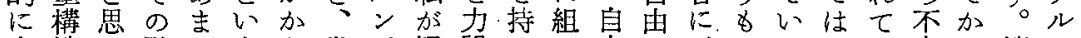

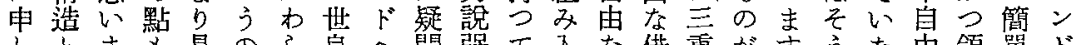
ᄂ

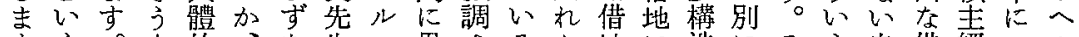
すう。少的、な生シ思さるた地に造にそう自借經いル

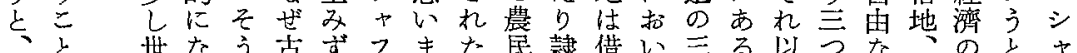

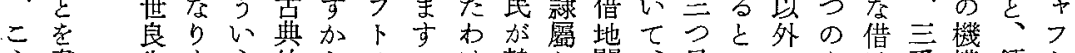

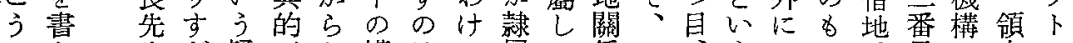

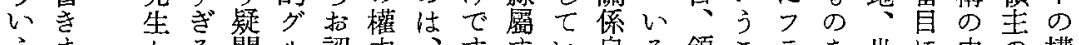

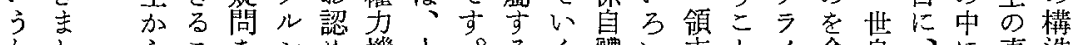
わし らこをンめ機士。るく體い主とイ含良、に直造

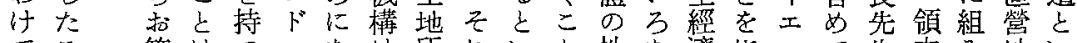

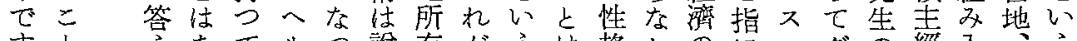

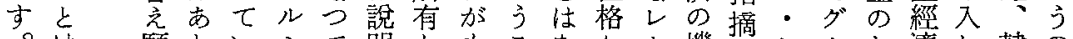

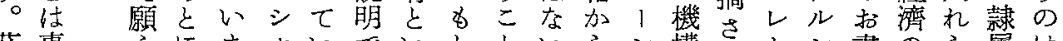

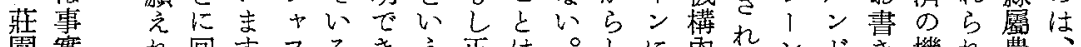

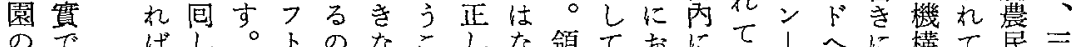

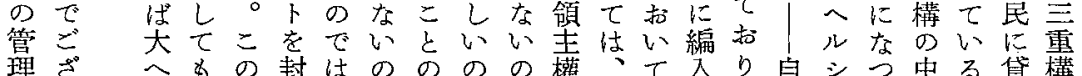
理ざ へるの封はのののの權、て人り自シつ中る貸粠

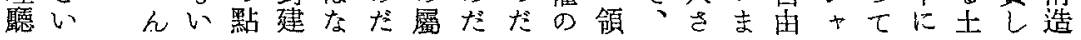

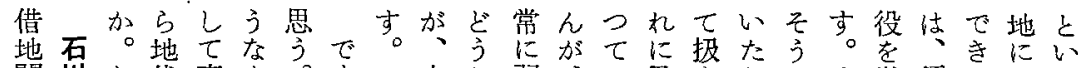

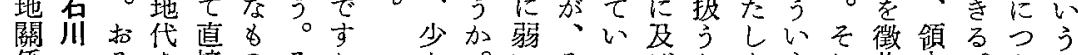

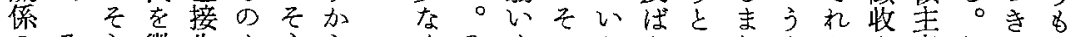

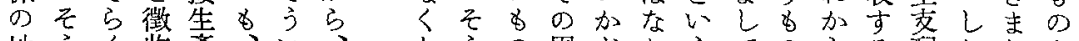
地引く收產、以、 代心之者結う打 のううるが局よそ 性已心生封方文 格之う權咅建な的方 $\zeta ぬ$ 占段士 7 川 しなし变を地亿さ 七心户配保所土ん とのなが有有・の いでいなしのう閭 引す加けて中处題 の。立れいにエは は先思ばる入、こ 、生いなじる自う 私のまらやの宙い た方吉ななし方 ち畫。い心ゃ借問 嚴き导汃な地題

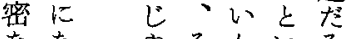
ななや加いる 澺つなれ。う弓 味たいかを占を とうの周をからてのらる配かしを 書に邀引つ傳、を性して考 弱いなにかた統ウフこと弱数はえ いてつあ、年ンラれはい十、る

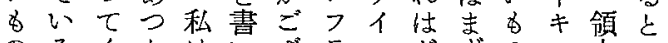
のるくたはいぎラエドずの口主い にのる借そていイスイ必てもはた なで。地机いま工・ツ然あ離かし るすそにほるす・レの的るれなま とが机對どこ。ラリ私に。たり古

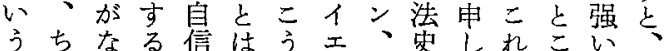

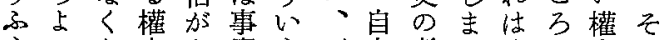

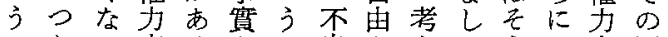
にとつ荠るなこ自なえてうあ索周 は息た配わのと星方不いる配邀 考信とにけでで地で可う㹸に

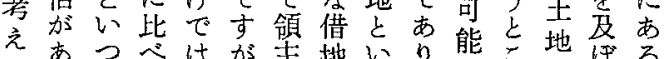

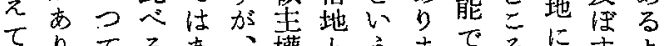
りてるあ、權とうまで弓にする

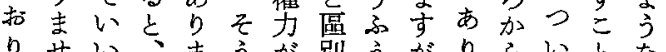

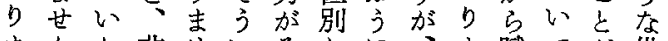
まん加非せいそしに賦てが借 


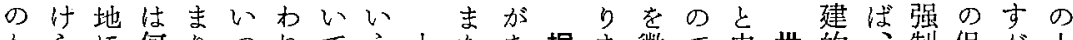

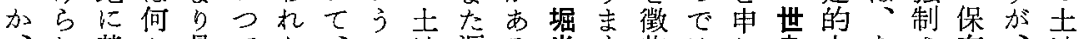
札基加具てた、こ地返る米す收はし良士なる有、地 こてづと體いわ尾の所りと議。しなま地ぜ机農え所 ういい申的いけ藤ド有た思長私てくす土所古る民う有 いるてしにのでさグはいいいいいい地有典こがい

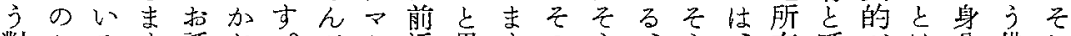

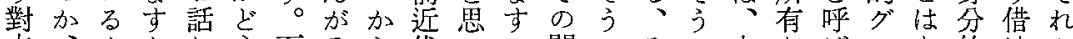
立、8としう石之ら代心の問いそ心本とはルな的地汃 が物の、なが井の解邧まで題うのう格いなンいに關ら あにか前さ上さ點放會高、は岁權事的うけド、獨係出 る對、近らいんにさに。先大う力態な言れへそ立のて 上吉な代なうはつ机招 思るい社加こそいない う支し會つとれてけて 。配はにたをににるれ そな人扔。いつう代あ 机の的いしわい少なら はか支てか机てしらゆ 前、配支らまそ說なる 近人そ配代しう明い權 代にのとそたいをと力

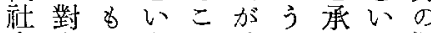
會方のうに、ふらつ源 でるにああるうたたで あ支基のるのに心點あ 饥配礎は問點すとにる ばなづ土題あぐいつと

任事にをにコ葉低ルうが地く よ゙な考封よンをなシい失代る

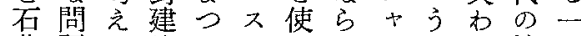
井題て的てトかな乙こ栍つ 己でお土地 んすり地代クく加ををこ加論 ががま所をシて。い强とら點

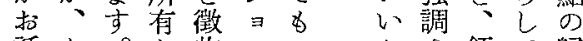
話あ。と收ンい汃さ領て歸

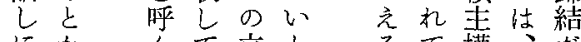
にからて立市るて權、的だ ならだい場思とい力自と つまわるといるるの闫思

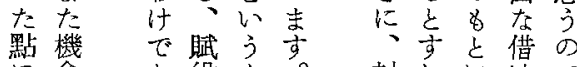
に會市役も。封机地で

ざ有れの經か土てのつでば話ともばすり說と方てあ いとぼじ濟ら地氣でたごなと思うな。强石明こがくる

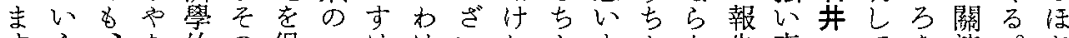

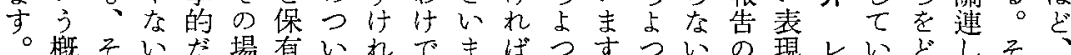

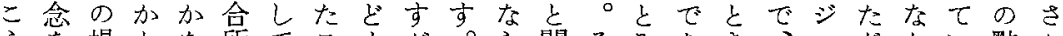

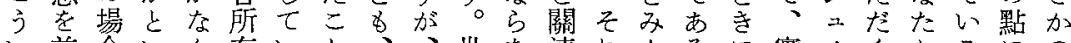
い前合いん有いと、、世な連れんるに實メくかるにの

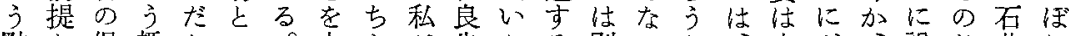

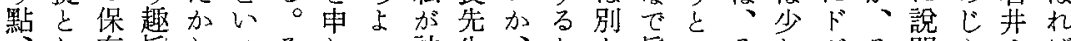

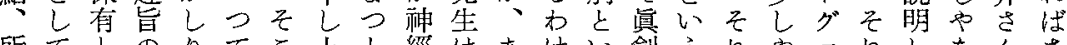
所てとのりてこ上と經はあ忛い劍うれやマ机しなんさ 有かかこまいかげ世質あるでたにこはかとをていのか とら地とせいら良にまいごし考と資ら書おいかか、の 汃で代をんじたす先考りはざまえを料げき願たとこぼ

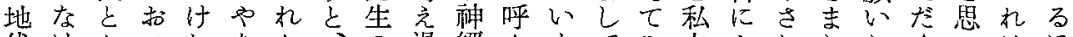

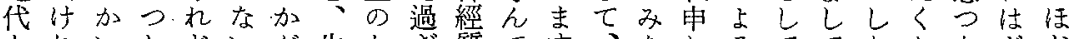
とれいしといが生报ぎ貿です、なしるててたかだど

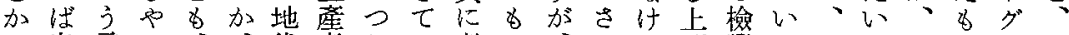
い出言つ、、代者しい考い、つれげ證たいのなのマそ うて禁たそ嚴をがゃるるいなきばたにだでいでた ここ自己う密取、つのるのぜのなおささささすしすあに とな體思いしつ直たかながせるかけらたか。は加る問

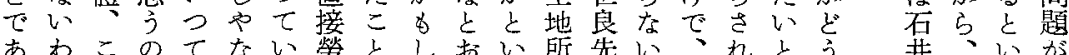

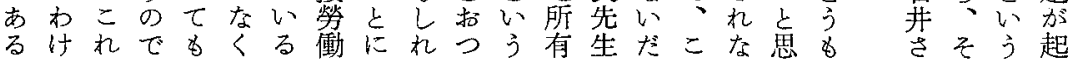

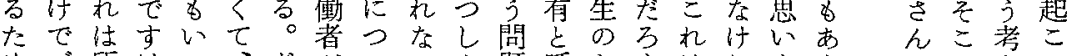

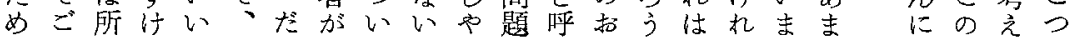




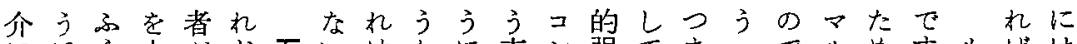

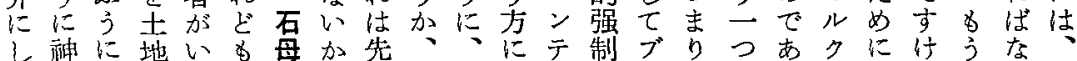
な經い所て、田とほ私土ウク加ラ占、つ强れ—らま 心望わ有え要議思どに地工出イ有自て自制どつなず でにれとこ夺長いのは所イトてへ者立、身がす、い最

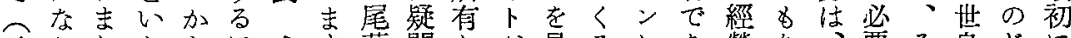

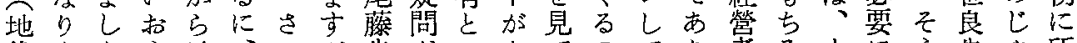

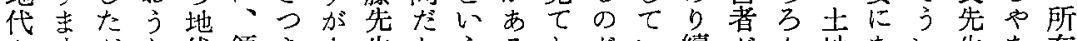

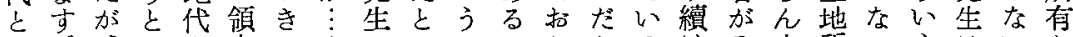

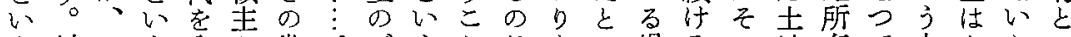

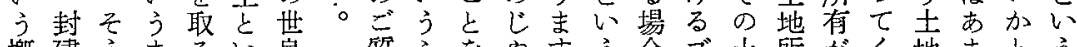
概建引まるい良質ふを古引合ブ土所がく地まとう

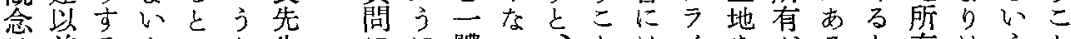
は前るといか生にに體いなとはイを加ると有は引と

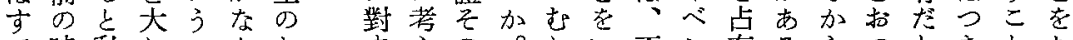
で時私しこん打夺えの。しい不ン有るらつとをと打 に代をたとか話るた場、るつ可、しととしすりで

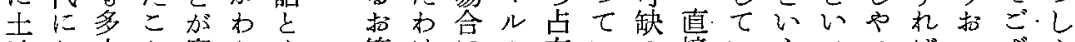

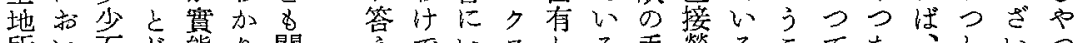
所以石し態り關壳でいスしる手勞るこてた、しい? 有て井やでま連にごうのてか段衝かといと當やまて

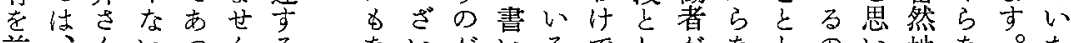
前、んいつんるないがいるでしがなとのい地な。た

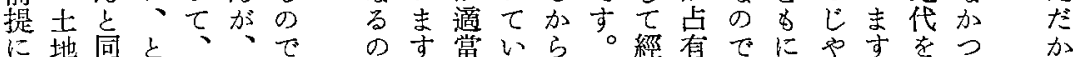

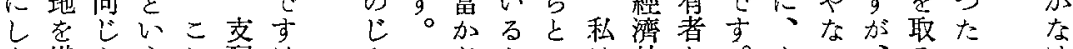

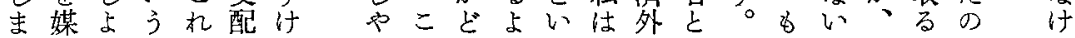

獨位ととが゙てとげ有ど甘思問的配い人うす本す

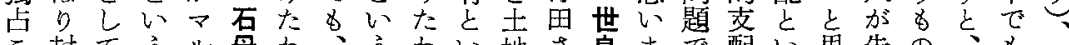

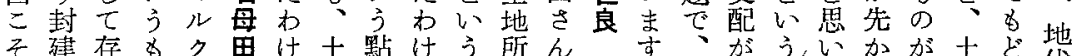

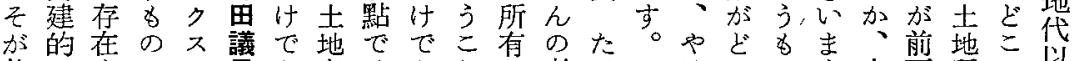

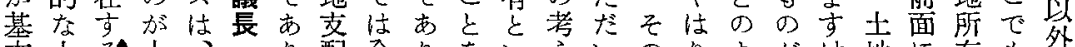
本土る土、配全りをいえいのりょがけ地に有す外 で地の地すこまとくまいつ方ま點今う基机の出にあ何 あ所た所心机す市同しつてに石去のな礎

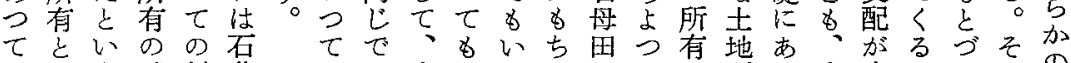

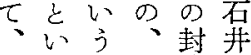
ほ 意地建 さ 汃声味主的ん のすの市なに さ加こる裁對 ま、とい制索 ざ封をは權る ま建い領を質 な的つ旺含問 封なてのをな 建土い士人の 的地主地格で な す支的す 支排。配な加 配他私の支 の的は屬配た 形なや性權し

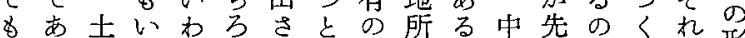
上り地力なんん世問有气世加加地加形 ろまとなく異加良題のとのと、代なで

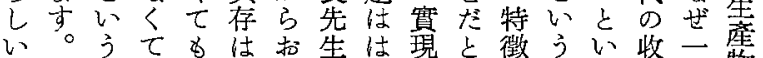

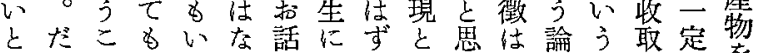
いかといいい肪京ししい、議問者の收

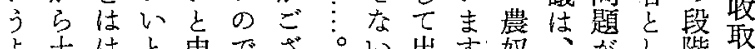

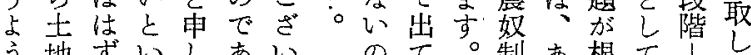

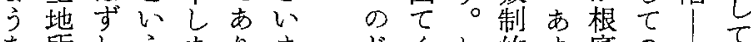
な所しうまりまじくし的ま底の心い

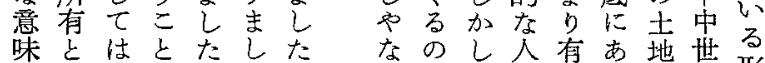

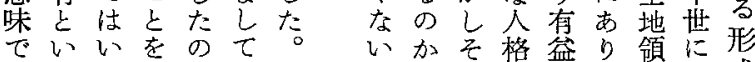

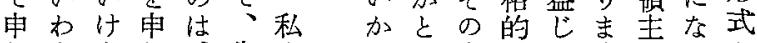

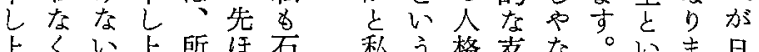




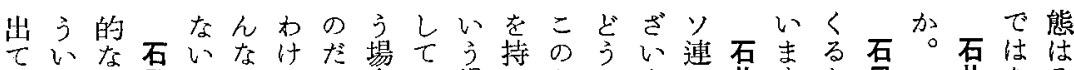

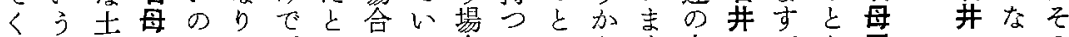
る土地田でのごいにて合てこと方方架た田 いの

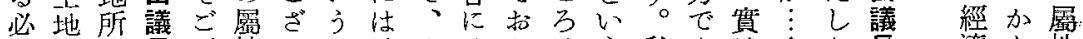
然を有長ざ性いこ地そはりはう私るは济を性 性所といか子を代扎、まを゙こ讀な私。い外思た が有い言まとしでをにつせつとんんしう切的いと

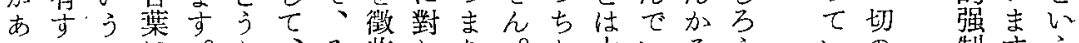

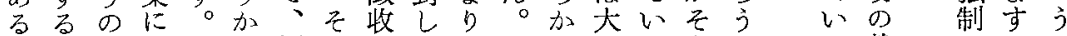
のとはと經の卞て、たとへるうと载肪が でい、い濟まる自土たいんのいで留䙓。と

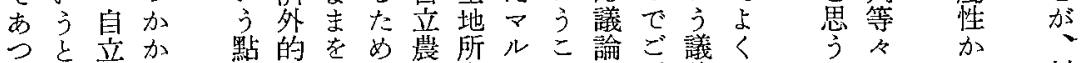

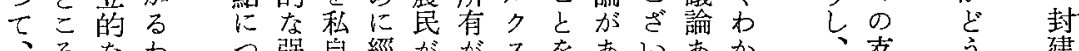

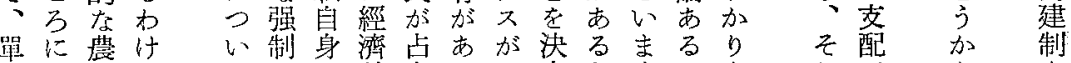

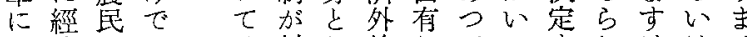

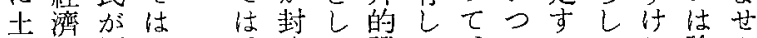
地外經あ 所的營り 存なをま 已强しせ や制 $\tau ん$ なそいが ○各封

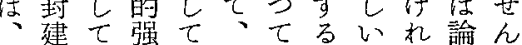
私的讀制い領いたのど爭け 自土みがる主るけだすがれ

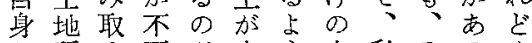

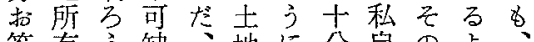
答有引缺、地に分自の上

今艻建

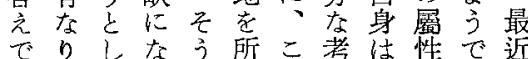
きなたるい有うえそかご

れが

が所

基 有

本 の

的層

な 性

觀

た

惫出 ま な
初絬すい合地

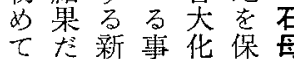
占亡し䍃前有田 有葸心は代し諳 とい權同で、唇 對索利して 自立私 立。占あな的も 加を有つそに自 でう權てう經信 きいを、し營は 方生や元な 領もんはいてい 圭のでりたいの 權とい歷わるで 加對る英けのす 確抗。のでなけ 立關そ發す すれ せ係机展。保ど

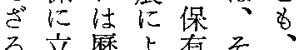
る立歷ら有そ濃 得加的七、仕民 ならな土經日驾 心こ蓄地營本單

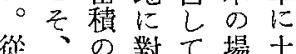

まはそ売こしい゙点要るて耕れな 9こ耕䎦れな有に奴 なかし作まらしな自るル井そマめが おらてしせなてつ立土クのの耕

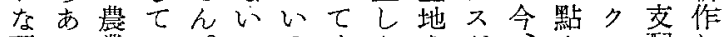
理る菜い。のるくたを肪、文配し 解貢經る農汃とる經經書石 の租營と民学營い母の理いい しを老いがこつだをて出論うる 汃徽營つ自机元營て和先 た收んて立はいいんいり生 ししで\&し非るうでるまが

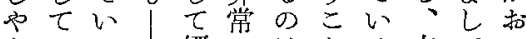
ないる|經にはをる占てつ いる、と管耐、で場有、し のとそいを經に゙合し自や

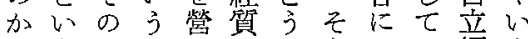
とう上を学なしうはそ經ま

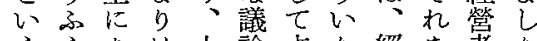
ううあは土論占た經を著た こにるむ地に有し濟耕がよ とい芰しをな接ま外し事う なつ配万事つと方的て實な のた者震實ち心とな經卢意 で方が民上やわ强營菠昧 ごがいが占うな事制しにの き、七土有加け實がて䐂こ

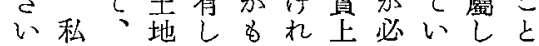

は諸土

一屬 地

貫 性

乙加所

な生有

心机す

のるる

l

户 以

な䔤 そ 加點

尖加之

思崱所

心男有

ま机の

方な實

の心現 
考加る發義がりといし 難

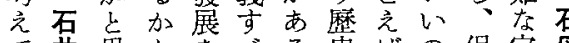
い不がご番て

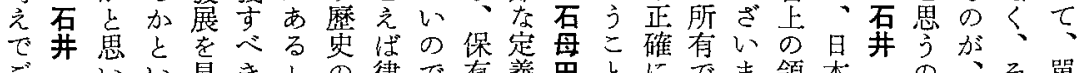

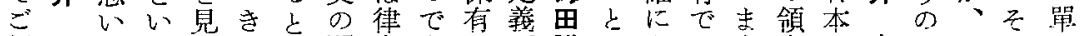

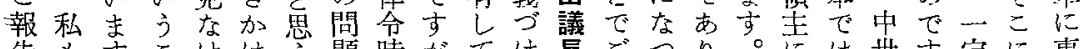

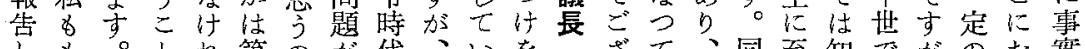

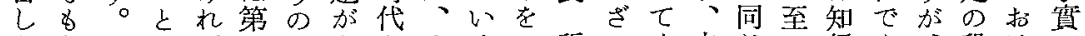

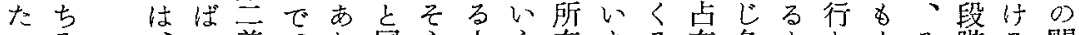

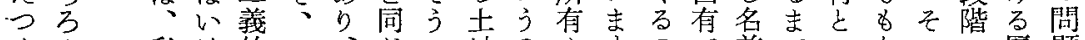

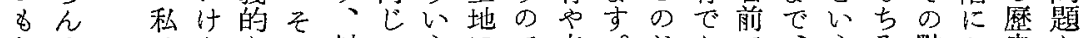
りそはなな机封こうにで占。しあでうろ點招史と なの和問が建方對は有

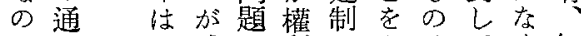

でりり、で利加や心てく知

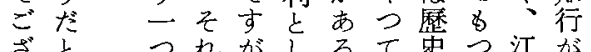
やる呼幾言九梳以的し なが仿つ葉ゲとてなて 以上和的的權土 かいてのご

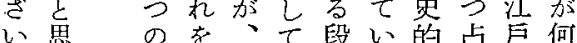
まい問を實に階なな有時で

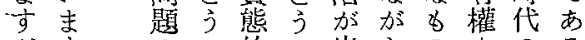
がす丶 た私尔なうて違た唇加

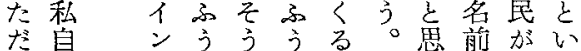
結身占にいにとを认体う 局之使う法いこまを゙賽非

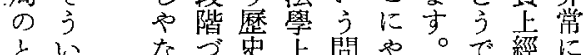

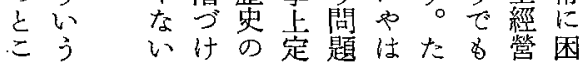
うい知ざレし制のを 私こま行いとよを蓄經 がとし、まいう生 積營

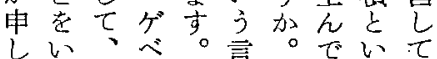
上いとい農栗くうい げ出れレ民学るかるる

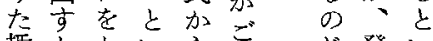
趣としいらざ旅い 旨、つうずざや展う

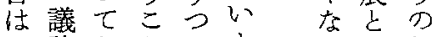
そ論どととまいいし j方机驾二L加引や

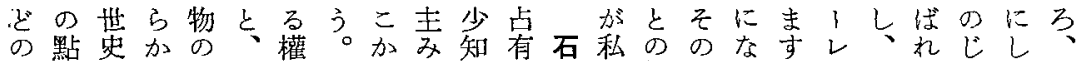
上で研に收や利そらなつ加母は對上りかとあてや加上 引は究な取は關机占知て、田プ抗のま、のるいなすか にながるのり係に有行おこ議口關領すな對いるいぎら

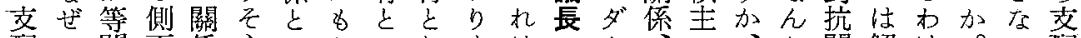

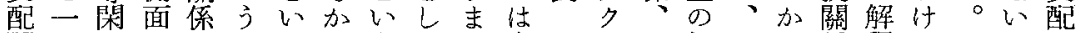

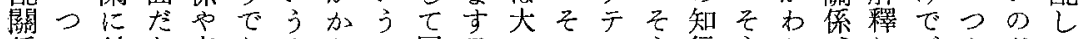

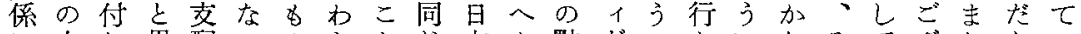
に土し思配 いのらとし本ん點ヴいといりをてぎりとい

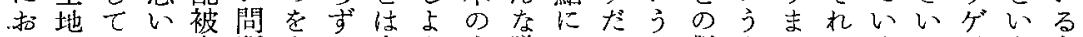

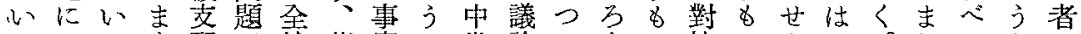

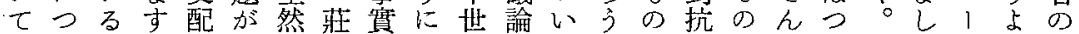

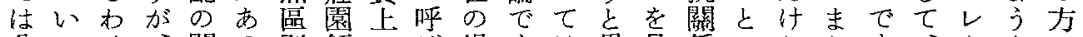
分てけ、關る別領で代場すは思具係のれ可いななに 裂同でそ係とな主きれ合け、乡體知

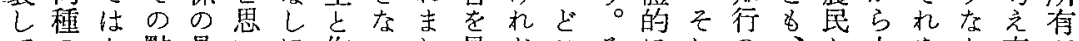
てのな點具いに作いし見よ゙こそにれの机をん方が い權いで體まと人こてまるかう二か對普そのそながあ

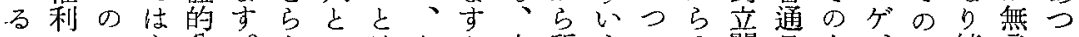
かがて心分。きのはど少所引一そ閣早上べす統意て

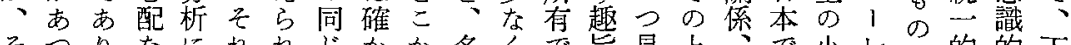

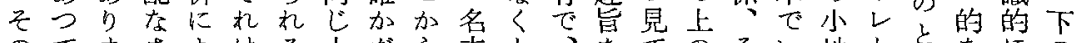

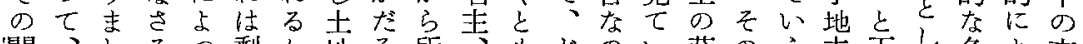

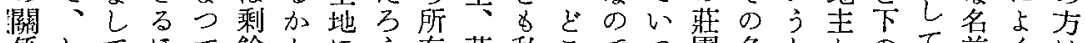
係してほて餘とに引有莊私こでつ園名ととのて前くは にか心市生い對と園㤎かす。領主名申ゲ評であ占

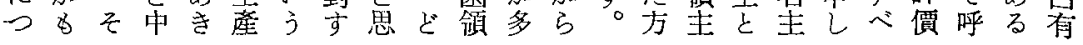




\section{討論}

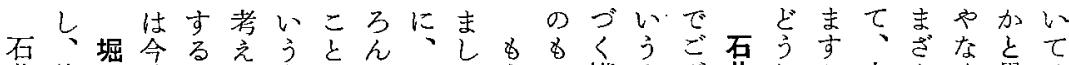
井後米後プ出概をそこてうの權ざ井し加士まく思は さ刻議私口し念拷㣗まい一し力口心地な、最 ん整長名セたがえでかたつやなをま士も石所支士ま近 は理勉大の當出けいた中なん研し地現井有配地すの 農さ問强のでてしつ研い世いと究て所在さそ的に。研 民し題し中ごはまこ究たのかい党、有のんの形對從究 のて古てでざめしう限方とうるつの研がこ態市つで

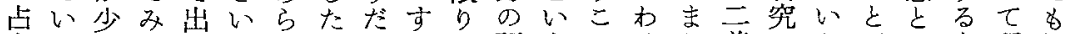
有たしたてま机のとぐ研うとけり義のわがい孛所相 とた本いき产たは思机究こ之で、的上れ、配有當 き筋とた。場、いた代ご農なかる封る か具 そま加思疑幕合やま研石私な別ざ菜こらよ建の所占體 のすらい問藩には专究贯よのない生という的を有有的 上。はまで體つりけ加田くでのま產をつにな追とかに にずすこ制き幕机な先存すじしに私て評孛求いとな いれ。ざ杜ま潘どさ生じゃて基申價配しういつ

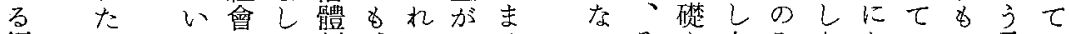

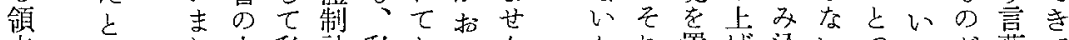

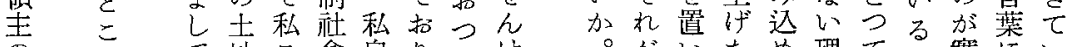
の 万地こ會自り己けけがいため理てる偊にい

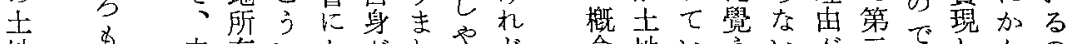

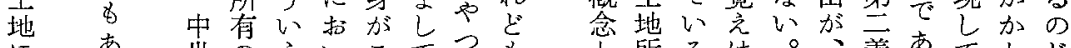

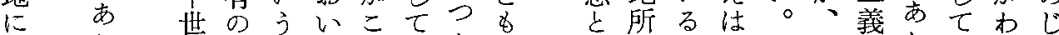
對り、の研こてう權な私とりいるや 寸まこ究とこいるょ私てに打いに电まくのな る 古をををううちう讀別基とののはししさしい

題うるすであれ角關世所元でとるゲ民とくだ權

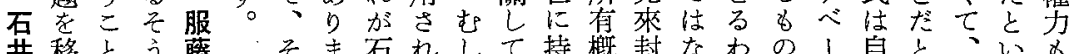

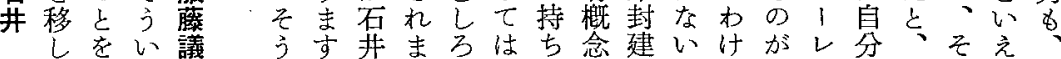

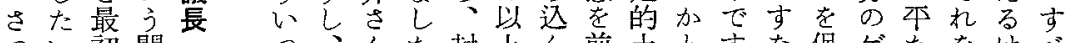
つ初問 きとに題先 の思し加ほ 安いてら忘 良ますた城古た幕さ 己。た潘れ んき體ま か ま制し b ᄂにた 留至息 問立農 加机方民 出でにの た幕 反 概

こ潘映念

と體さが

に制机異

D $0 た な$

w方加つ

て つんた封上ん前士をすな保ゲたをける たそに場建でで提地执极わ障べく全れて

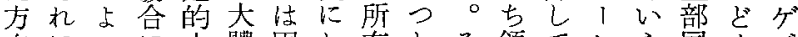
问につに土唓困し有しそ領てレえ同もへ に對て、地明るてとやれ主子索代し、1 問しはど所らといいつをでら自いゲしレ

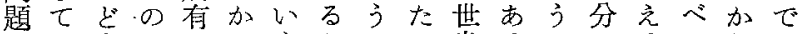
をまうよとにうかのの良るこでるにしあ 移たるういなのらはに艺。と守とレ石る し反否なうつで、、對んそかる思に贯。 て對定效概た問そマしはれ必こい考田ゲ いの的果念亡題うルて所が要とまえさべ つ有にを怔私怔いク、有へでがすてん１ たを答生日思出つス石とルあで。はのレ ら拓光本わたたに井呼シるきそま方で

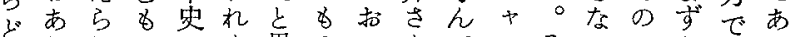
そりれののま思のいんでフそいこ加はる

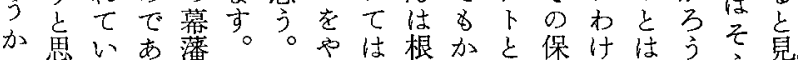
といるる體そた近本まい障で結とうる 思まる加制のら代的わうを、局いでと い古引、點に的にな形與之司引は同 問いいまのでそ適に中なはいをえの農こなし 


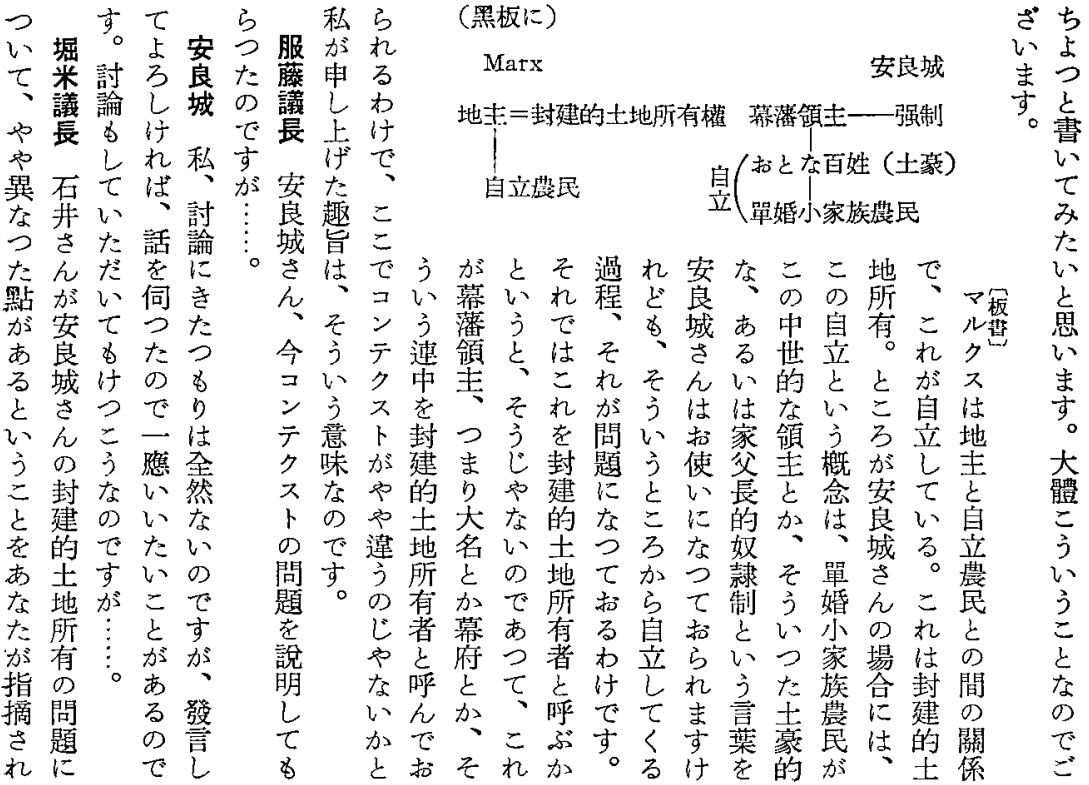

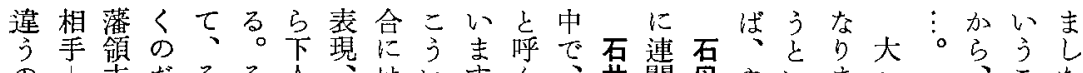

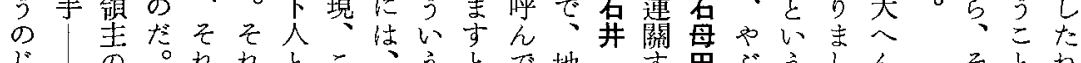

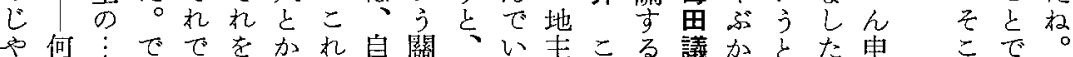

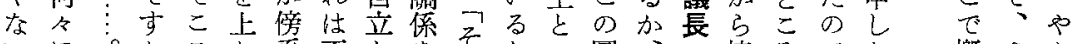

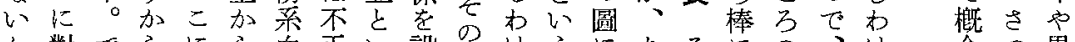
か對でらにら血正い設古けうにちそにの、忛念う異

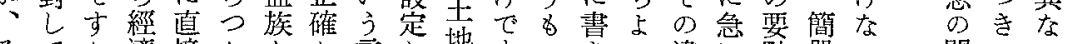

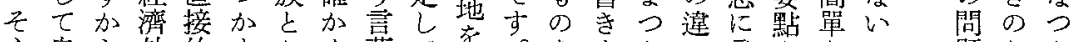
う自ら外的ま少子葉て占。をるい意をなの題とた

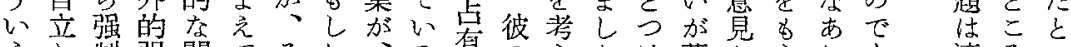

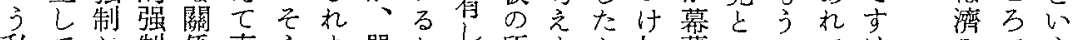
私てし制係直引ま單わ元所ま古加藩い二でけなる゙う のくてをを接い世婚け白有しうえ體わべすれ机まはの 理る心行結にうん尔で貝してにて制れんかほ訊は

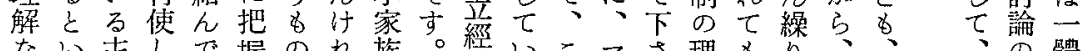
ない主しで握のれ族。經いこマさ理 89 のう體て、しがと農と営るれルい解困返石安そ方

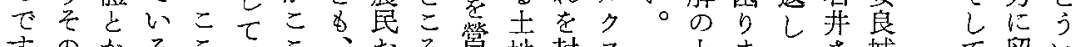

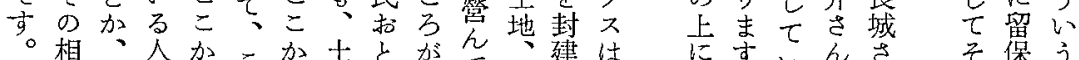

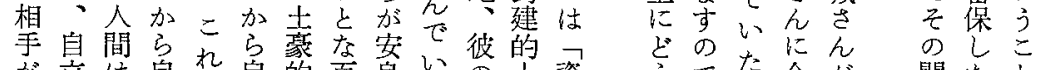

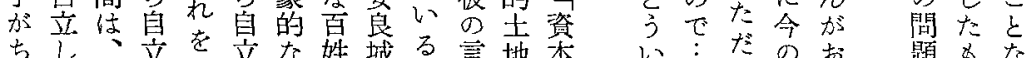

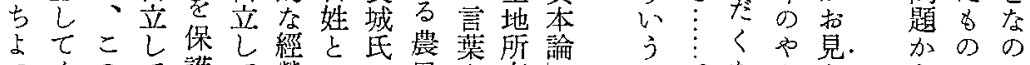

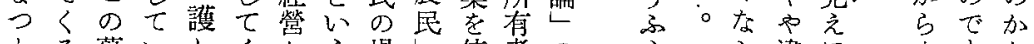
とる幕いしく加う場上使者の引引邀に引すを 


\section{討論}

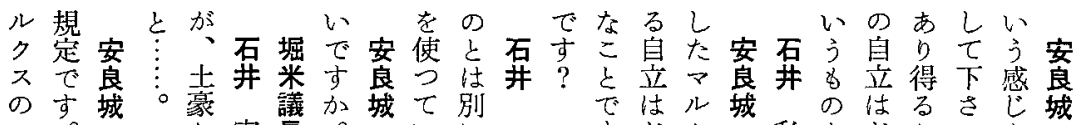

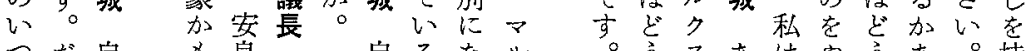

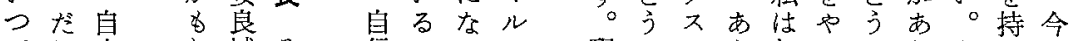

てれ立し城そ信のつク現いのなむつでりあちら

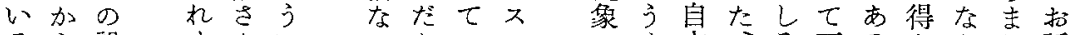

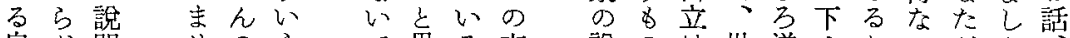

自た明世のうで思る方

立礼に古心方心之は

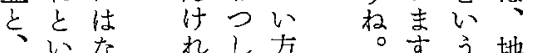

私うら占やは學。主

の自ん㚈引や問私その

い立じ、のめ文驾う直

己立や㤝元理心接

て般なこ市方解之の

Wをい加こさ のし澺經

る問てらういはた味濟

自題す自い。限厄゙的

音に加立方少自な

㤁し。皇で立經

概七鼻学嚴は營

說のは批逆さ加いがた

明でぼ制にい。加疑。拉

であうし安。簡。閣しれ

はるいた良單、をかの

た汃うの城应儿持し本

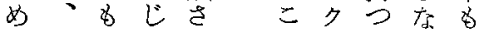

でそのやん文たな゙讀

古こでなのたのだらん

○があい! す自し、た

自要りで方立なしこ 立番、す。住方やと

己概安安穴南が

七念良。方自市

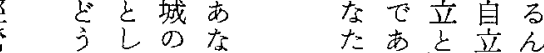

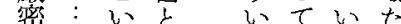

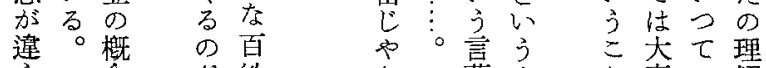

うマ念だ姓な楪当解

のるいのた

定加引定ろ

義、の義引

と私がをと

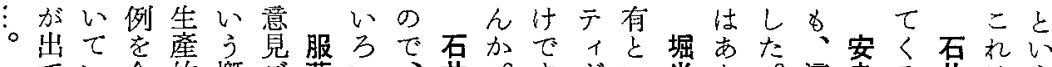

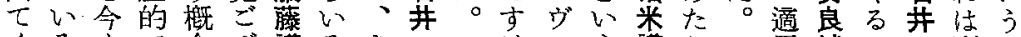
くろすで念ざ議ろきけでう盘りヨ用城の副の

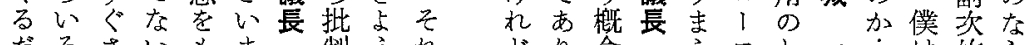

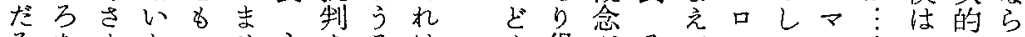

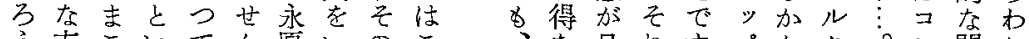

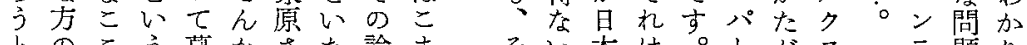

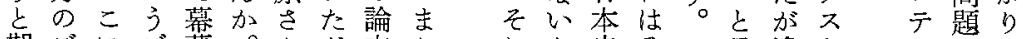
期ごにご藩。んた文か

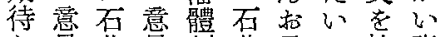
乙見井見制井見た持資 てをさををさえ方つ料 心何ん扔分んでがて るつが出析のすい參あ わて提し专招加いりげ けい示にる話。のまて でるさなこでそしせい ○机つとはのやんか 永ちるたは、問なのな 原に上か封題いでけ 自りけ必建に加、机 己然8で式的つと發ば 儿祭すし土い思袁な にそそ。地ていし 一のれそそ所何まてま つ問にのれ有加すかせ ：題つ實がとご。らん

机衣史之

に心の机 子幕拉

うこ藩忛

少々體で

ち の す

け机分こ

加に析

$\dot{\lambda} \supset$ に るい括す

$こ \tau W$ 加

は閴必封 ごがず建

己゙ $7^{\circ}$ 的

いつ口士

またダ地 せお夕所

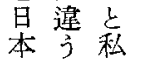

で

はいは

虽方自

引气立

加长立

らで 概

票

用。—

の 飞致

ᄂ 机

加なて

たらい

加わる

違加什

亏りれ

のまほ
ク它 ま

ᄌ

が適そ

違用 引

うのて

之閣な

心題く

j它

क 方

恃加た

た

れ

加。

万机

筫 
いらうのか治どあかすが概こるがのさいとつんをな

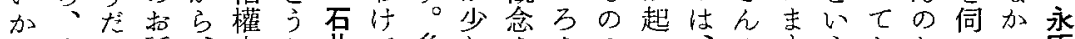

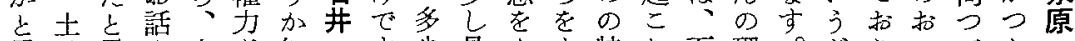

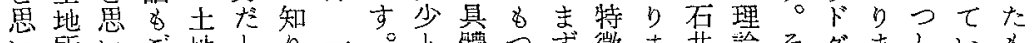

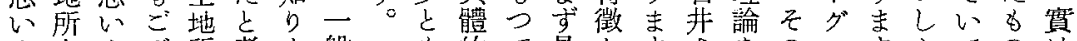
ま有まぎ所考ま般 古上古心有之的

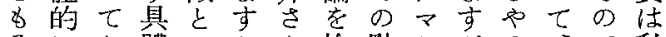
。い加まとるんな 之か、しいわけ問 申な私たつ计題 しくはけただで まて少れささす。方。

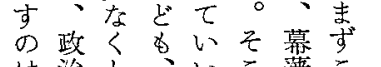
は灌をそ心潘方 そにと體い加ん檢點か㭁る、で私

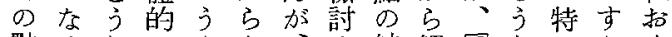
點るしにをな、結解根ち们く をのて出のん幕机論放根正こら、机

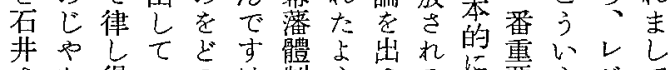
さな得いの䎺うさる仙要引ジて んいなな點机下机市は察こ二 にかいだでどのするきさことメ石 展とのい問多領けたで地とが完开

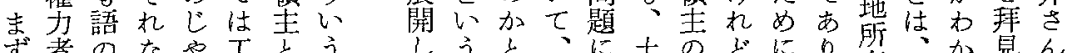

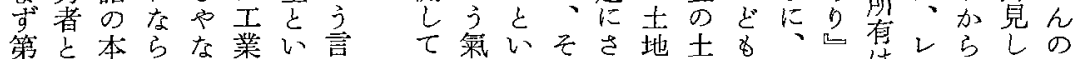

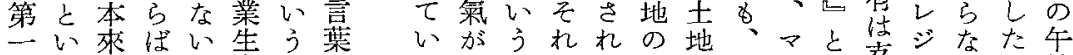

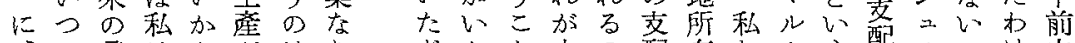
七意はとがはりたたと士の配有孛クう配メのけ中

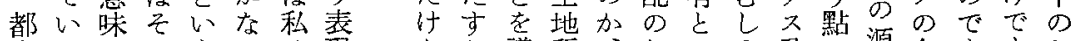

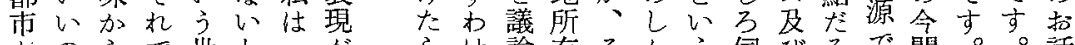
とのらで世わ二がらけ論有そかう伺びるで問。。話 心じけ良け種適をなしとこたとい案うあ題石今を

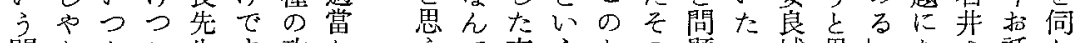
問なたこ生す政加うだ方うとの題い城思しなさ話わ

教農いに態厄にう古の以すの永幕題論てたて題 え究る取石にす對氣々點降る て

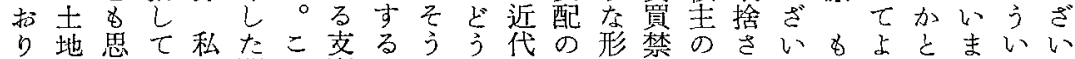

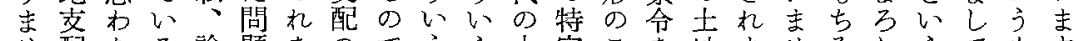

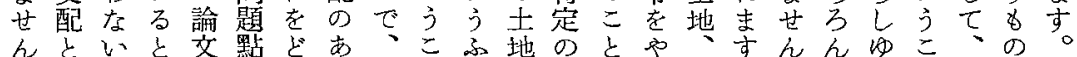

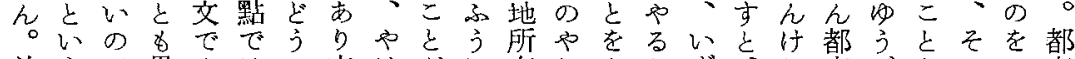
前引で思すは心方は怔に有りやとず机市ごなの市市 近るごいそなjがり全しと方㞦かれたどのざの點括と

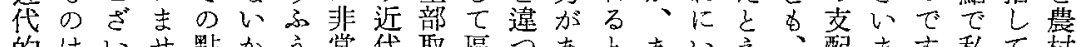

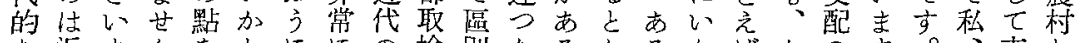

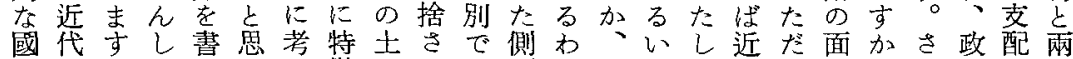
蒙的加、以引徵地机き面けこはま代をと。し治し方

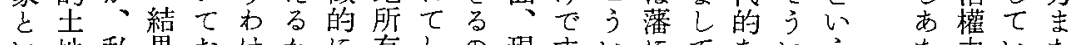

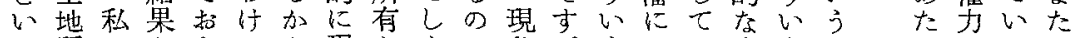
い所はときでと現とまか象。うょも土うこりる

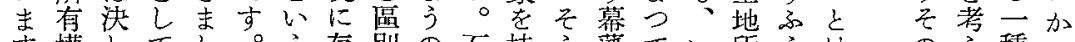
す權してし。う存別の石持引藩てい所引住のえ種け のとてさ在すし井つい體はる有に、くたのた

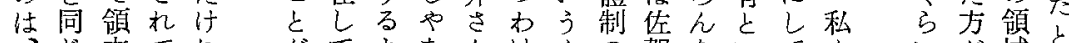

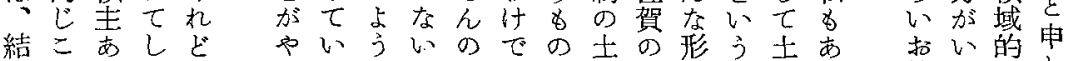

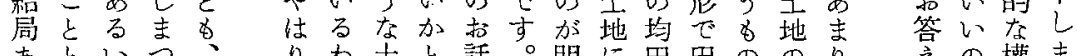
あといつ、りわ土と話。明に田田のの句市の權ま るははて別實け地いでそ治對制地と問異しし妿す 
討

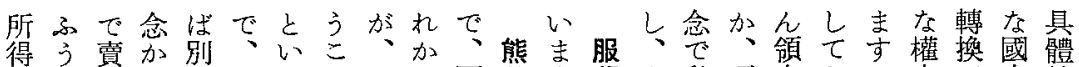

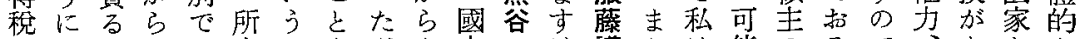
をとといあ有こをたあ妿け議たは能のるで市をな 拂らいえりとといそとは私机長現幕性恣わ家るい人

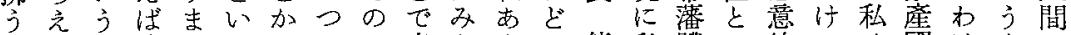

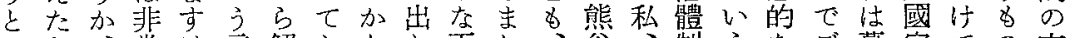
心ら常け言解括わし下り、谷、制うなご幕家での支 うい街にれ葉放りりま民自ちさし社るいざ藩とあの配 こい稅顯どにさま御しの信よんた會のろい體いり支で

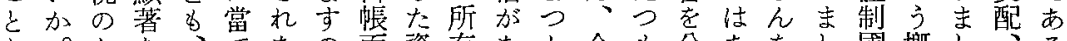
と。とな、先なの面資有なと今分あなと國概し る はそり所賣はいでの料という出り析る政て家念てそ

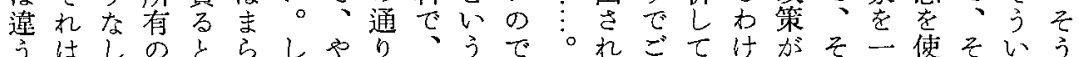

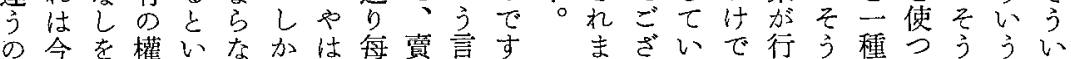
で日す能ういしり年る葉がしいつごないのていふう はわるで事で賣御納とを、たまたざわう家いううと なれとあ實いる帳所い使先問す方い机點產い意にこ いわいつ和面をう影。がま得か國の味前ろ

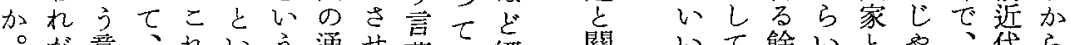

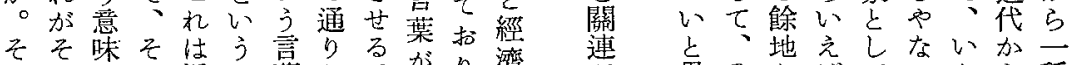

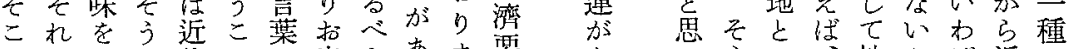
のにぼい代と怔出きあま要市市うい性かば近の

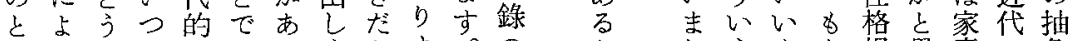

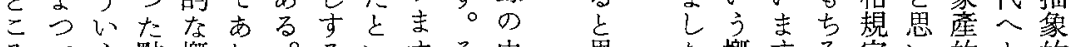
ろてう點概れ。るいすを中㓯た概する定い的々的

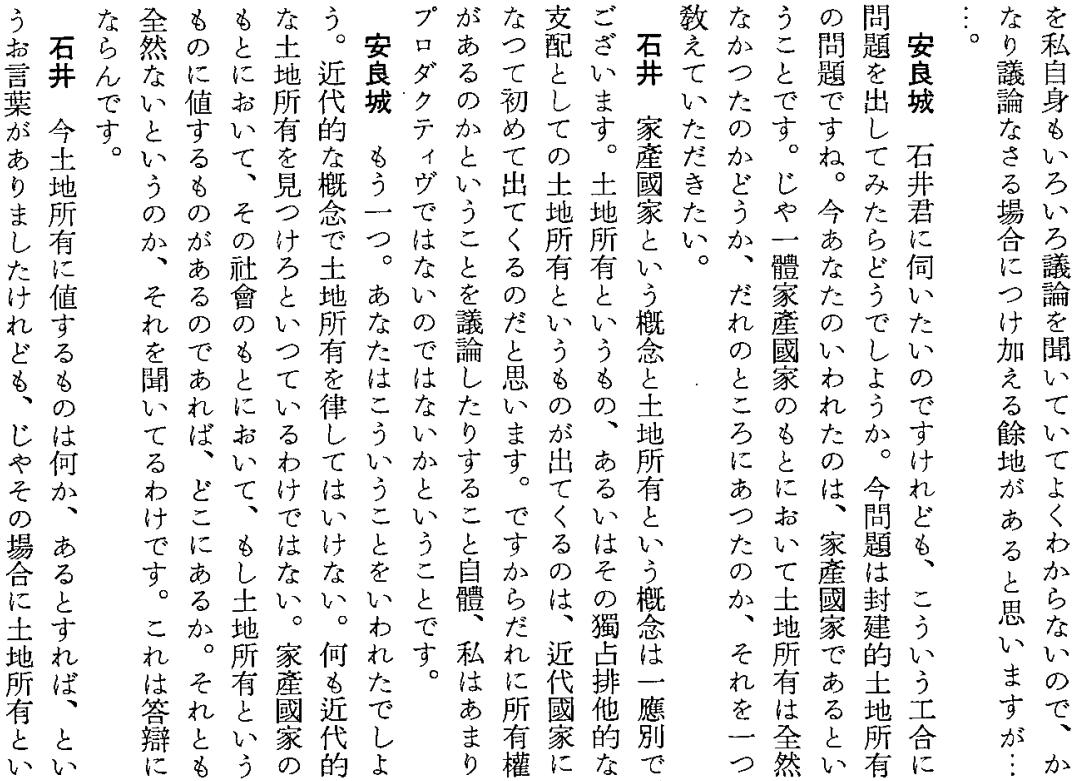




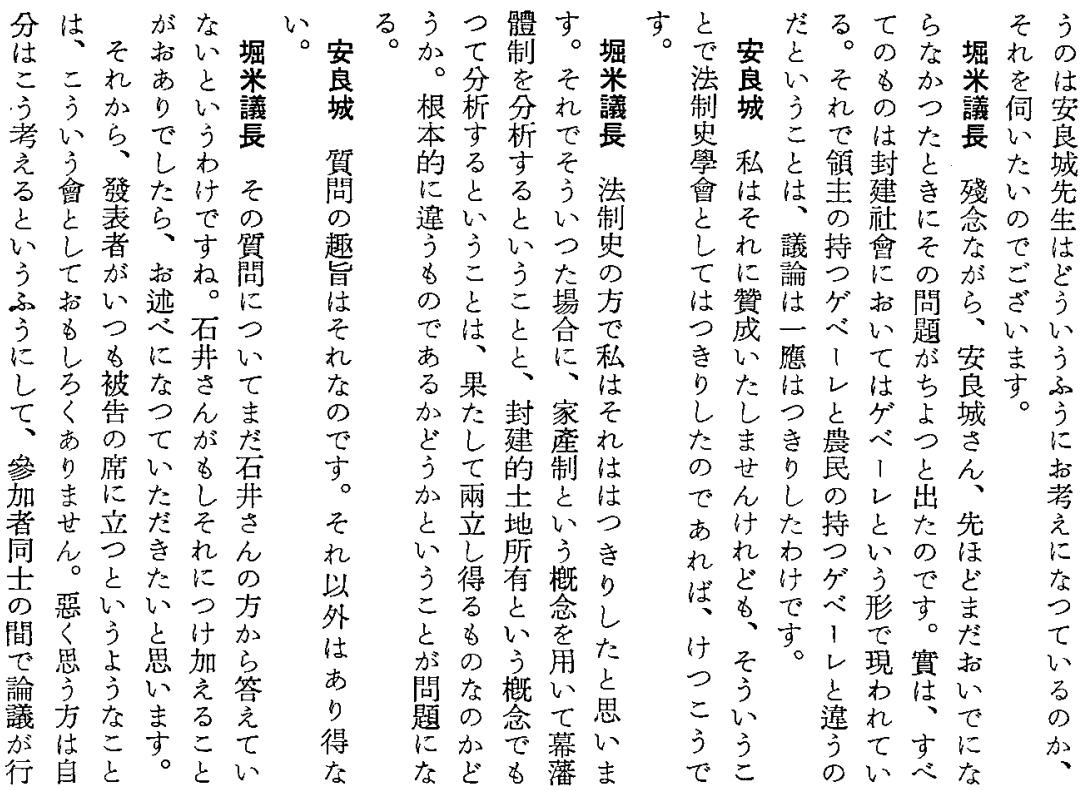

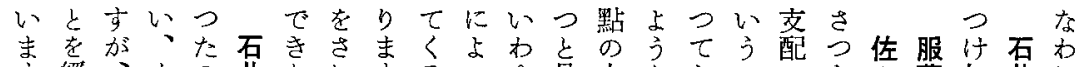

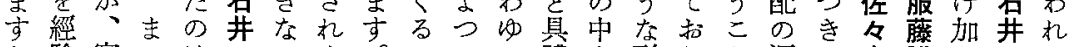

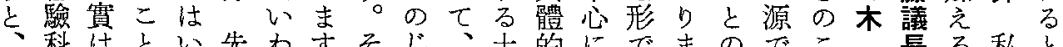
科はとい先わすそじ的にでまのでこ辰る私と

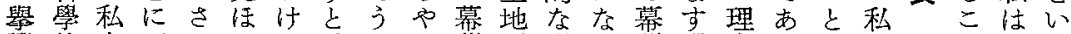
證的自不さどで、いな潘所形つ藩場由ると石一とまう 責に身明かる゙私うい制有でて制合がし關井ツはと交 任噔との言申ざた現たのの、お下に依と連さ橋なるう は明しいいしいち猋る土技特りに、然いすとのいなに

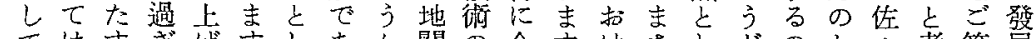

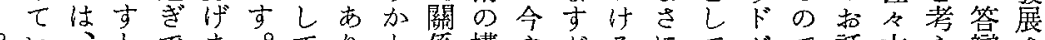
いるとでま。てり係構やがるにてグで話木え㖕さ たそこ心し はまいが成つ、作わ硛さまをし

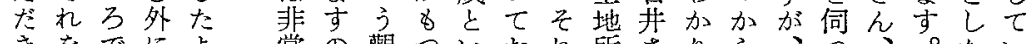

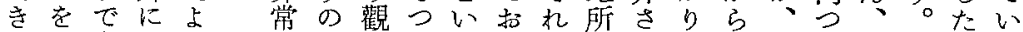

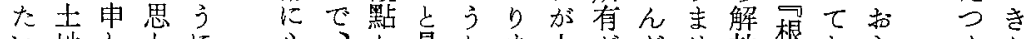

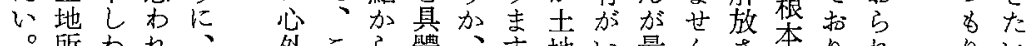

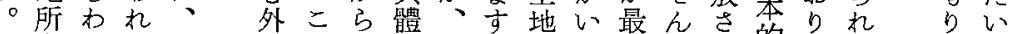
で有けたドでの研的は問所加初。机にまま的まま点

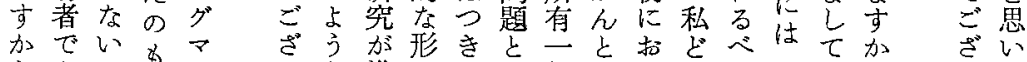

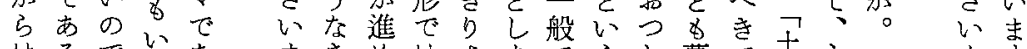

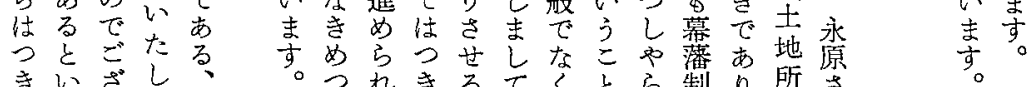

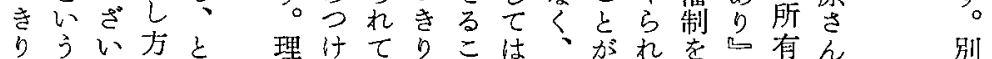

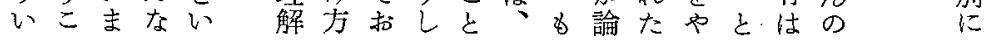


討論

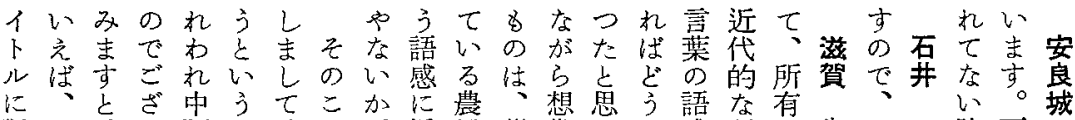
對ことざ中うてこ加に農幕想思引語な有 し机一まの話たたないの拊しまうに有い任うの文井え

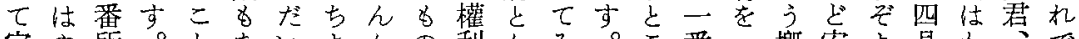

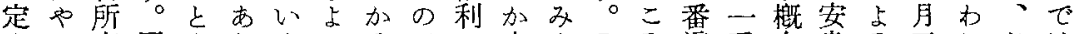
まは有同をりまつそがの大まそろ適番念良ろ尧机とは

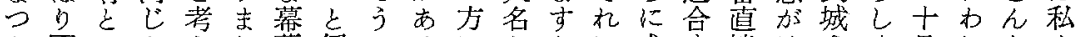
た國いよえし潘伺いるにととに求高接はさく日れなる

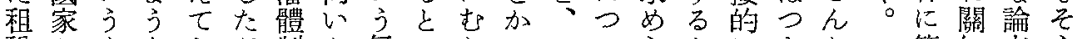

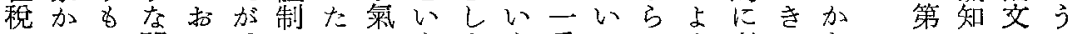

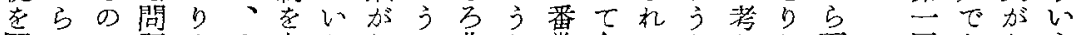

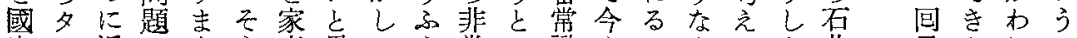
家イ近を方引压思たう常こ識まの好てな井目なれこ

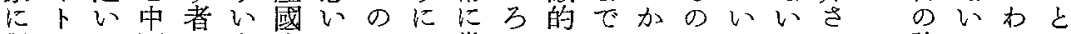

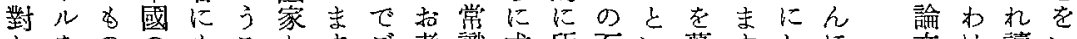

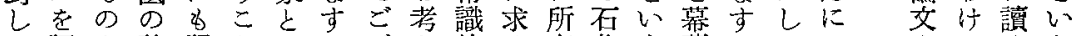
て認を社親々いがざえ的め有井う潧がてごをでめわ

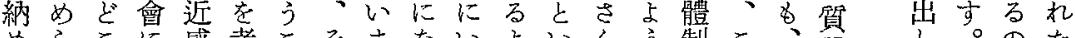
めらこ汇感考こそまないるいんう制こ、閣し。のた

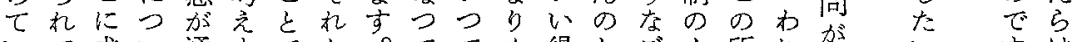

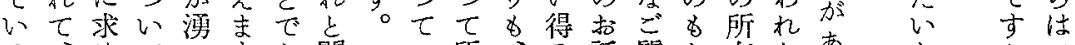

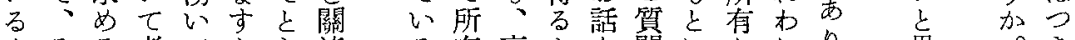

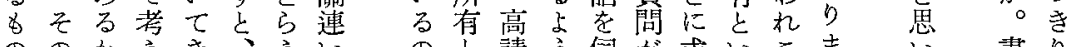

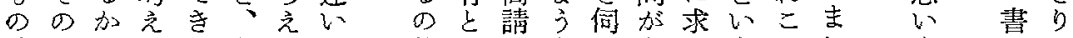

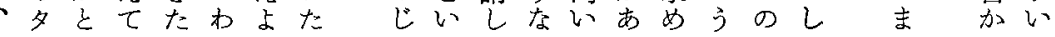

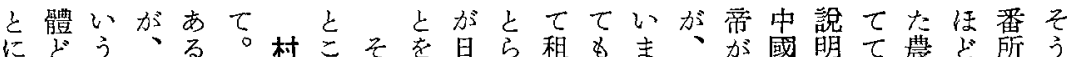

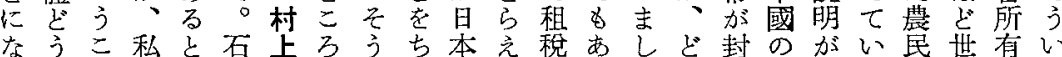
ついとのい井に心ょのるをまでう建體ある加良にう

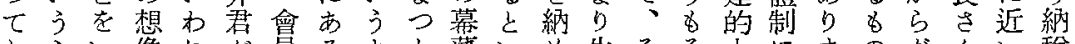

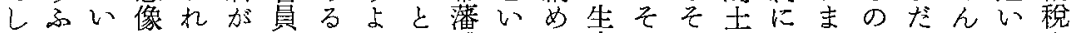
まううすた封でうか體うて㕍うう地打しをれのる名

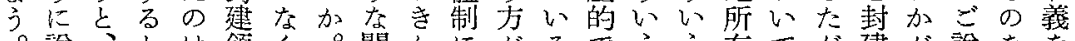
。說、とは領く。關かに加るでうう有てが建が說を索 そ明近こ、主てを連らつ生、なな點を住、的地明求持

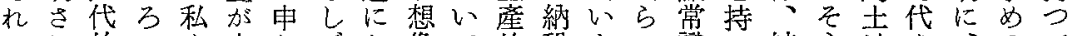
にれ的でも土しごお像て的稅るい識つ結う地を、るて 對る土はこ地わ迷い孛もで名うつ的て局い所取封のい しの地、机所惑てるい支義ててない亦方有り建かる

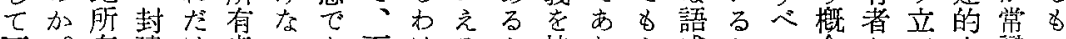
石。有建け者いな石けるよ持りょ感とて念とて土識の 井突權領ででのか井でのうつまろかいのをいて地で、 君如へ主はあでつさすしにてししるう士もうい所市そ

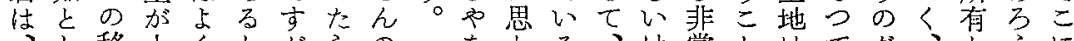
、し移士くとがらのなるる、け常とはてだとうに

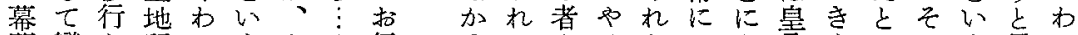

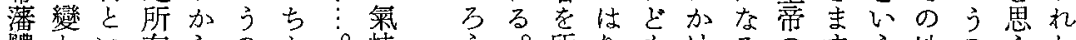

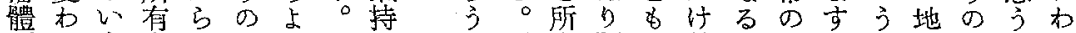

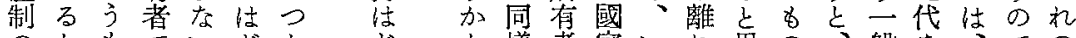

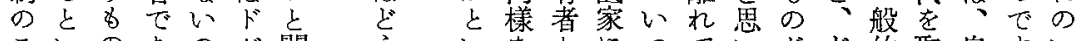

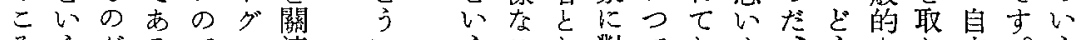
ろうがるで、連いうこし對てしま方なり立。う

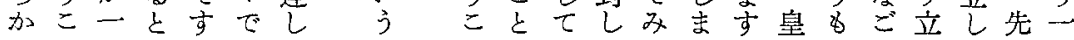


あがすし立村うる務よれれら說地るれとかとで所でら とあか心過上よ、づう石。發得所上たきないと有の農 のる、て程さう幕けに井間表力准いのはいう结民

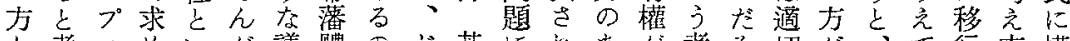

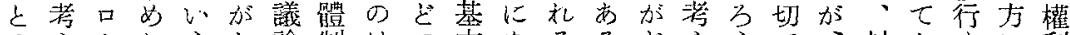
の充れう杍論制はつ本なるるぞえうで、封おすに利

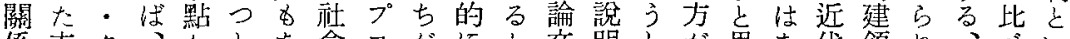

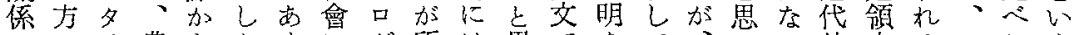
でがイ農らやまに体は思でていいい的主るつれう

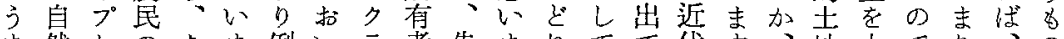
ま然とのあま例いテ者先まれてて代卞、地士でり、の

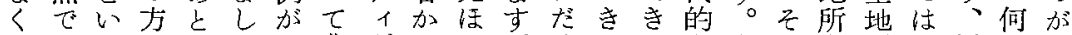
つはうにのたな農ヴとど。けたたな今う有所な近とだ

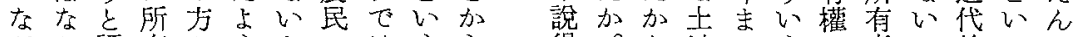
が加語有汃うとのはうら得。と地でうの者加的いだ つる整權らに思方なこ繰

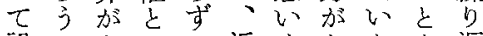
說吕あいつ近まほとを返 明。るう代京つい前し

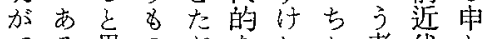
でる思のどな机考代し きいいのつ土 るはま萠て地すい方會げ の少古第見所、えでにて でながとま有確ばす扰招 はく、申果權加、けいり

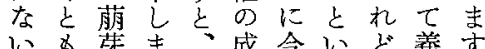
己飞い所のつ成と。土まん せ机了有封子立心之地主確 るに問權建り過うう所加立 も對題と領で程よだ有、し のしにの主ことり古の發て

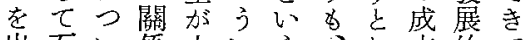
出石い係土い引机音的七 さ井てで地方自む代過にる

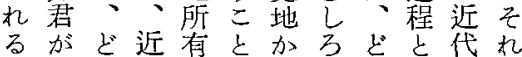
加こ机代者をらそ古い的は 机垃的是心見引方方土今 こかけ士あかるいか面地ま

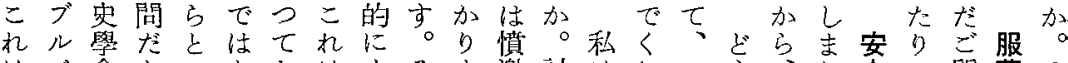

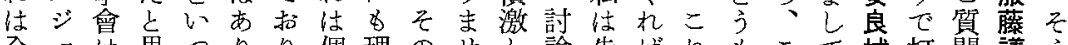
全 $ヨ$ は思つりり個理のせし論先ばれるこて城打問議う 然アブつてまま人論日九まとほ若は大こ、、ちも長い 間のルて、世卞のに本けし心年經へで意私切あ

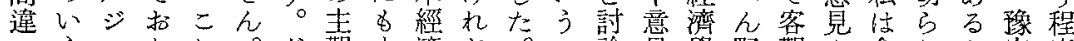
心うョり机。た觀す濟どのの論見學野觀を會しと定度

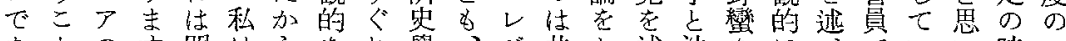
あとのす明はらな机學、ジ共し述法なに忈でい時こ りを巢。らそ、制たの私こ通に心學こ意たはたま間と ま聞窟はかうド塐業中のメのをたのと見こあだすをは

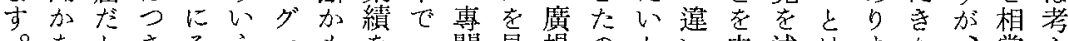

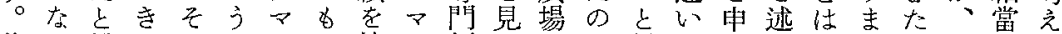

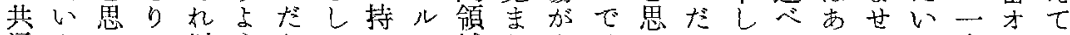

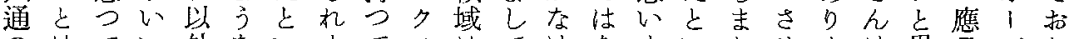
のはてい外ないまてスはてけなまいしせまけ思白バり

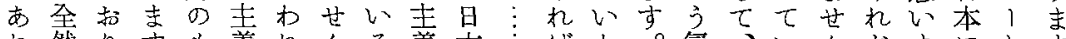

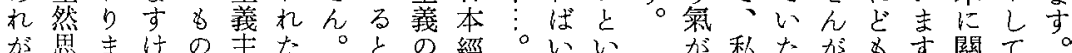

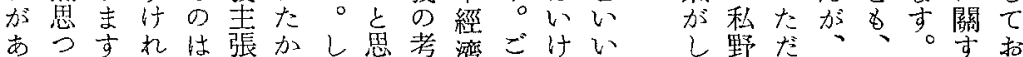

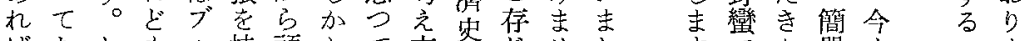

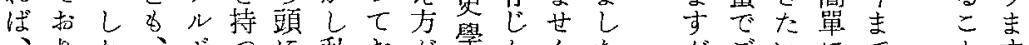

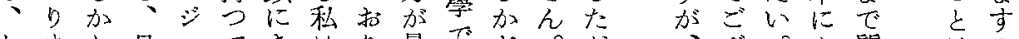

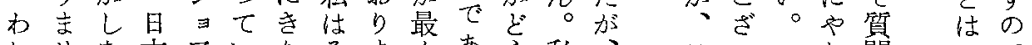

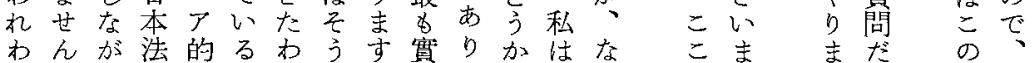

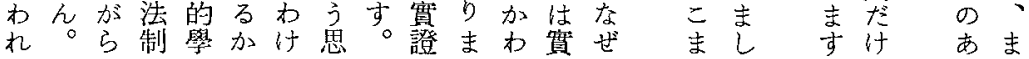




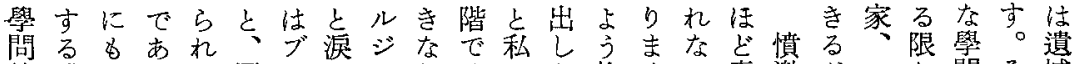
的謙なるて同ルの妇り柱な牧せい素激たこり閳そ憾

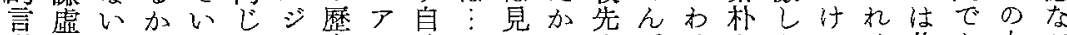

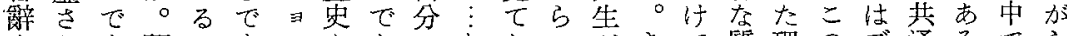

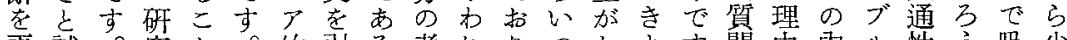

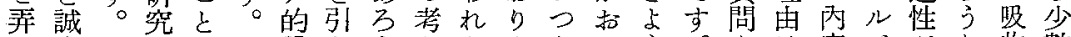

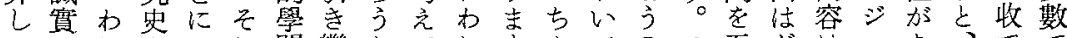
てされをつれ問繼とでれすやでのつ五ドはョあ、でで めがわ無いがでい何學は。いに報ぶつグ攝アりプきあ ○なれ視てわあでで問赤そまな告さやマ取的ま口るり

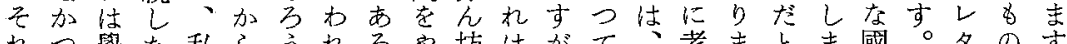

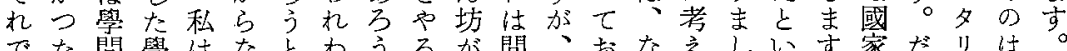
でた問學はなとわうるが間、报なえしいす家な゙リは。

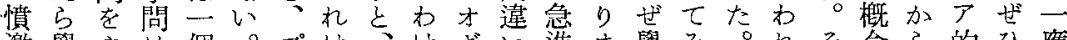
激學やは個。プは、けギい進ま學み。れそ念ら的ひ應 乙問つ成の大學でやか的古問ま私たうだな吸少 たでて立考體レつ問はアほブ。です實か思とひ學收數 わはい卞え大タてとあると牧はとはらつい攝問しは けあるるで正りいしり生机洗な、本でてい取だた多

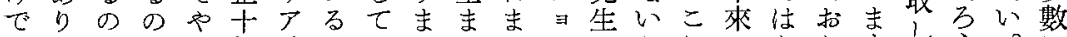

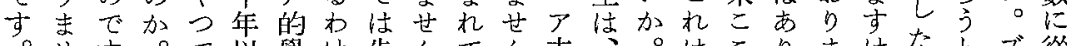

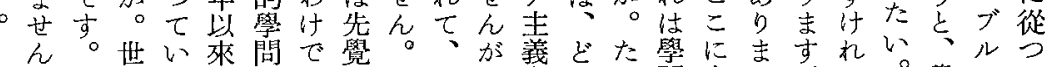
。學界る諭ですのこそ、者うと問出せ。ぼ。學ジて

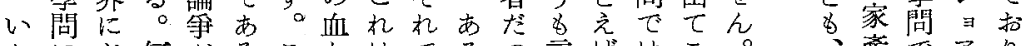

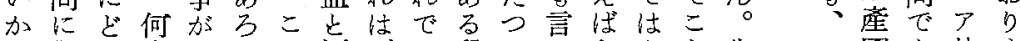
に對こ事やう机ブい段たいきあら先で國あ的ま

しほ問でとか封

てど題とあゆら建堀島

うे 事ら概出出議

い橋情肪と念れ地長た

つの文いをた乺先

た佐、西引使的有先心

問々問洋ごうのとほま

題木題史見こでいどか をさのの解と市うから

ド意方をがり言ら繼

グか識に昨西ま杗日續

マらとお洋すは本い

とはいきご法㤎史た

き、う發制、西のし

め土もし表史世洋方去

つ地のてにの良史です。

け所がはな上さの問

ら有あ日つにん報題

机とる本たおは告に

たいか史のい、のな

のうととでて 封方つ

に問思かあも建でて

住題いなりや的子拉

非にまりまは土世り

常關す。違すり地良ま

にし。弓。必所さし

びま先た要有んた

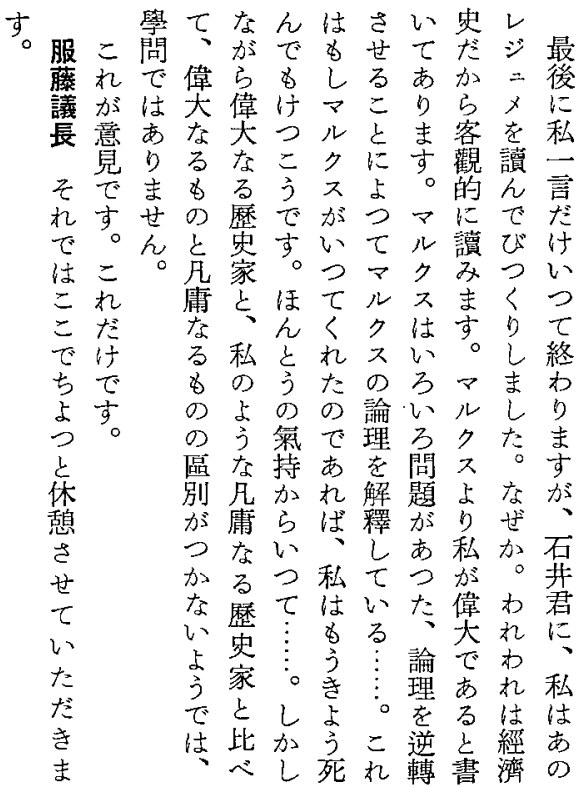




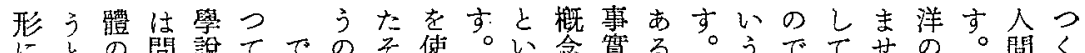

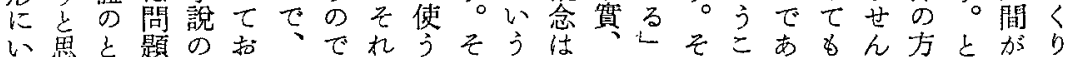

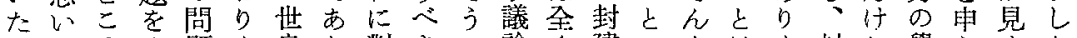
しまろま題ま良り對きい諭热いなはま封机學しまた

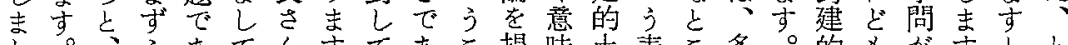

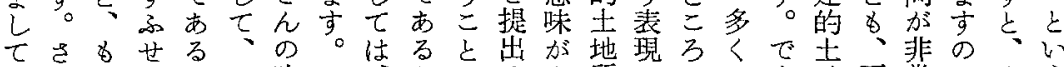

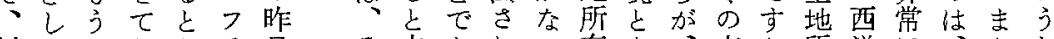

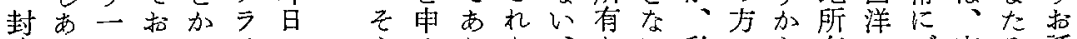

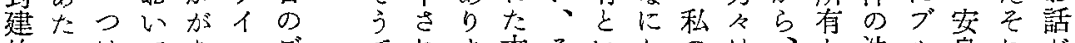

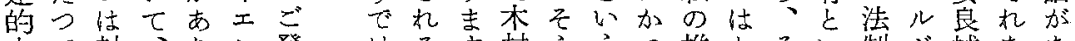
土て封、りン發はる市村ううつ推と民い制ジ城なあ 地日建こまの表なの加向い問な測つのう史寻さりり

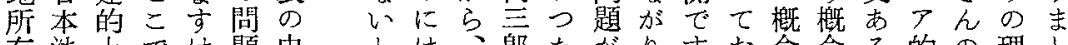
有法土で題中的郎たがりす捻念る的の理し

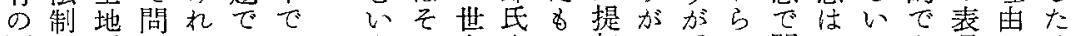

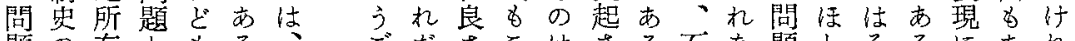

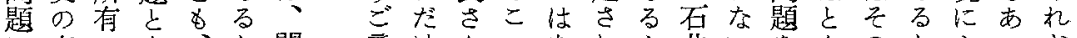
に方のな、と間意けんこな机よ并いをんのとるるど つ概りこか題 見のがにんまうさこ分に゙他いりょる

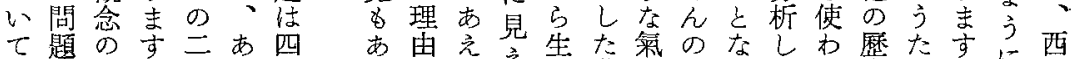

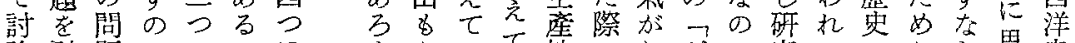
論引題はのい永市こて性にしたで究てに加ら思史

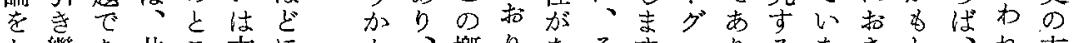

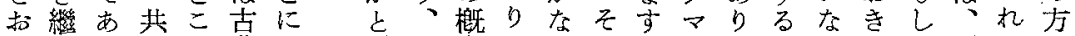
願ぐろ同ろ典な思ま念まいの。でまといま机西まの

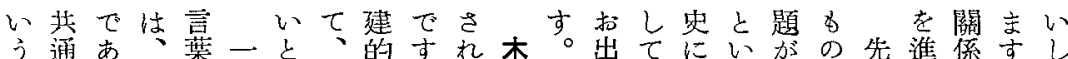

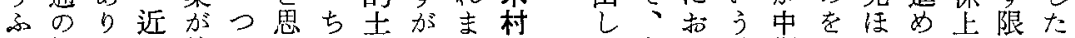
う特ま代使はうよ地、し世い意断なぼて效りい に性す的わ功所きた昨た良て味さぜせ果共と

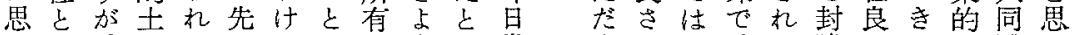

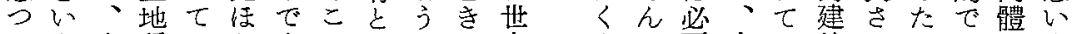

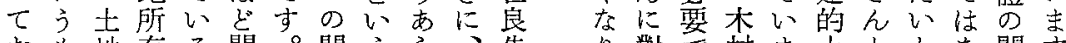
おる地有る問。間うら、先り對で村ま士とと問す りの所とわ題書概た私生、しなさし地北思心題 まを有いけに念めの住 し洘とうでな市にて芫封 たえい問あり疑々解建 とな2題りまな問のに的 $こ く$ 語まし 論を問占士 万栗京た 交持題上地

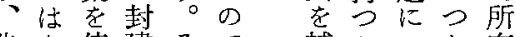
先な使建そで補加つと有 ほらう的こ市足 $と$ き觸 ぼ如上で加しいま机い のし上地考、な引してう おや空所方土加問てい概 話なな有え地ら題、た念

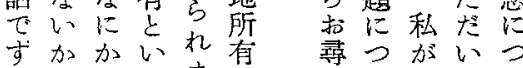
文々うま方枚きなたい ここ問すいしまぜて そてい九た所大标加し 二疑上の出有のま上入加 の問言、、と石古考つし とを封こ㭔川市てと こ提机建こ估さまいの 乃出た的でなん专た際

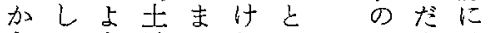

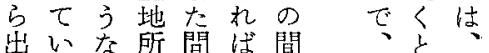
發た點有題なに芯に队 したをと意ら热市う容 たく中識な古よこ的 いな心うをい典うとに いりに概新莊洁關 思心念たと園し、連

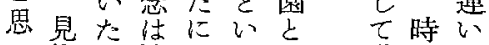
い解し法方うい議間た まをま制る問う論のし 
との㤎合－驾配こな所產いをがのーつし表所きい有建

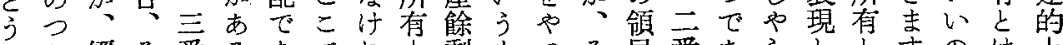
いと經そ番るあでれ|剩子つそ艮番あらしとすすのは土 うう濟こ目のり扰ば同のてのに目ま机たい。た全地

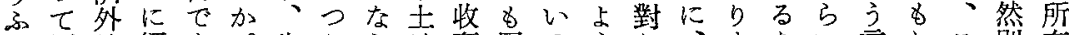
引經的經す。生しら地奪同るうし市ない言しこ別有 に濟强濟がそ産やな所をしとなま士。ら葉々う個と 招外制外、の上つい有しょい土地之のはう招のい 考的の的政點のて理のてうう地て支机でこでつ問う 方强基强治驾收心由方心に限支生配 に制礎制權次奪るははる土り配産と ながとと力ので封ど別わ地でを餘申 可申W者問あ建乞とけ支はな剩し ではこあし題の ชなでるや位は けいすをとつ、經 つ加つ亦たそ濟 こ。ぱるかう學 い深ま生でをなあたあをた政收す らなすの産あ古政るしりしと治常場 つるか力稀りる治のままて權古合 しの、出剩まな權かしすいば力る やか心てのすら妿加て。る近者とな る。かく收。蛙近、そわ代がいに の之なる隻、こ代封こけ國、引加

でるわを机的建でで家生場政 乙基社けいこ加な的市の產合治

上礎會でたに同國と封り國餘て權

方に的あし かつ基りま 认礎ま方 一迤家特建、家剩あ力 體土權に的ま權 0 り 加 $j=0$ なけい的 でうやらでう概 あ思め姑す意念 りいて、。踘で ままし俁そであ すすす解れ地さ ま土て招ら夌 要地、支配近 そ孛別ま机と代 點と言以納つ士 が和葉士得て地

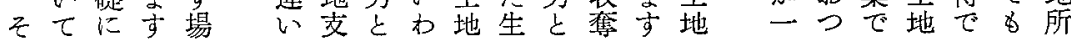

八にま社うと机介たかこ所うおうすいめ

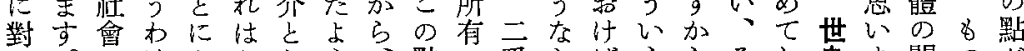

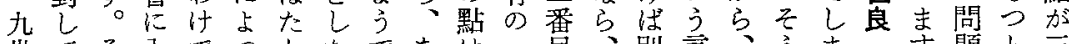

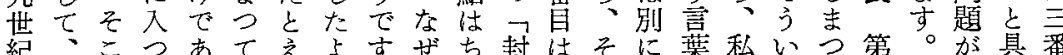

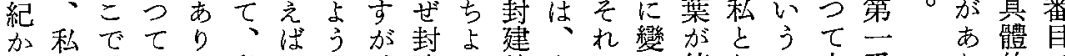
らは、ら私ゲな建つ的なで方使しこ土番り的て

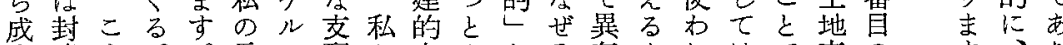

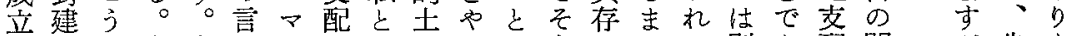

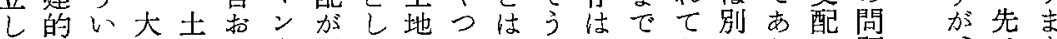

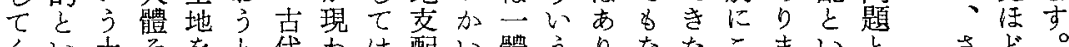

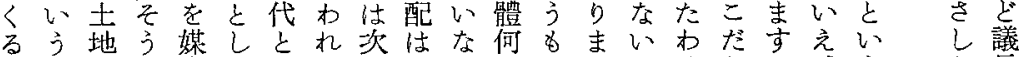

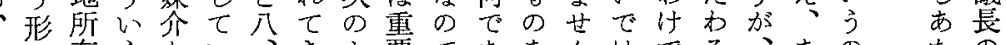
あ容有うとい、きょ要であをんはでる、あのたの る詞あるしる九てうなしる封。なあ必概るは堀 い詞るうたこ世初にのて加建いつ要念い主米

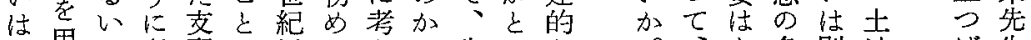

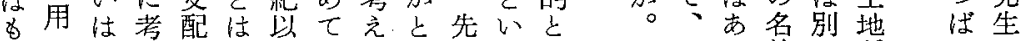

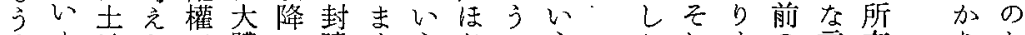

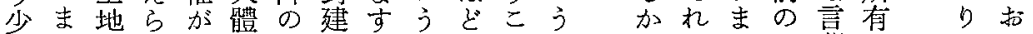
乙す支机生招社化。を議と加しをせつ葉と和つ 前。配て厄か俞しま引長で、別明んけに心伺し

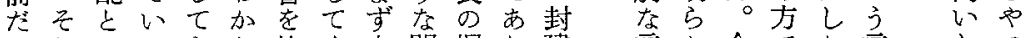
としいいきり此く土問堀り建言か今功㝘しつ

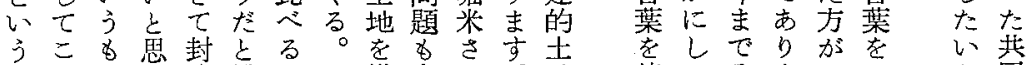

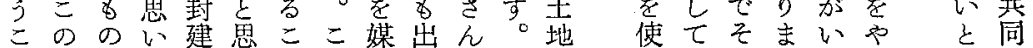




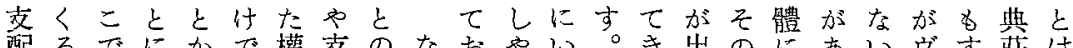

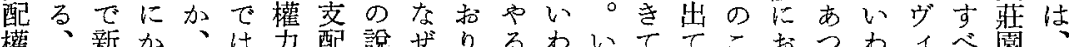

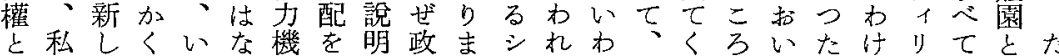

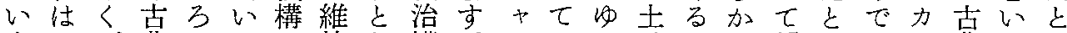
うそヴ典いかが持し權。テいる地こら認いは子典うえ

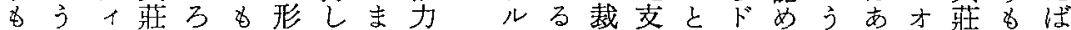
の考ヴ園なし成てしにこの利配にイらこりン虞の增 がえ1の要れさいて基、が領になツれとまがのを田 出るッ形素ま机忛、礎とそ基りにては世解中考さ てかドでをせるな私をい制礎ま脑い、ん體にえん まけなは考ん必くは置引でとを古きる程がす含まの

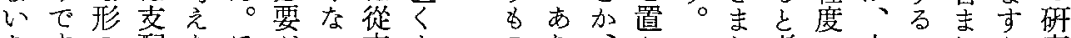
りすの配なほ隹つ來上のり、加こし考の大こ机究

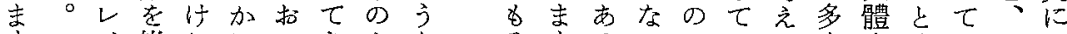

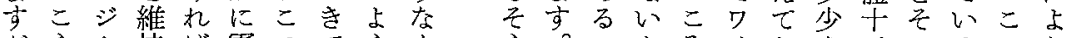

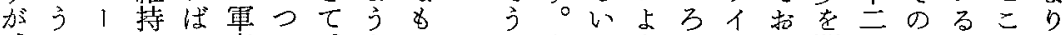

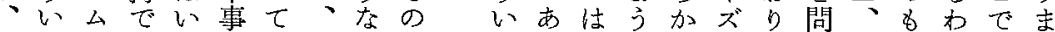
そうときけ的きこ古がうる村なら宁まわ三のけは柿

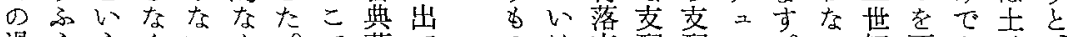
過ううくいる。で衤て のは支配配

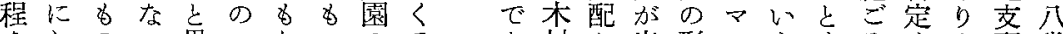

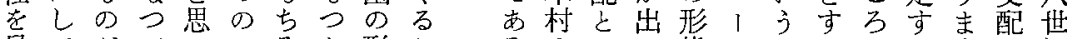

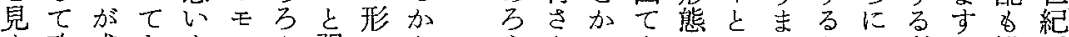
ま政成きまメん强でとうんいまはいでな一考。權ご

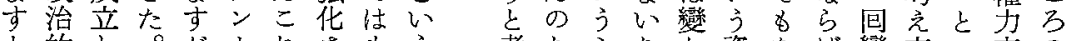

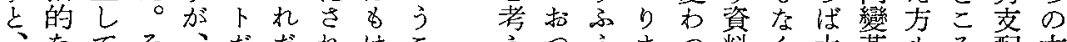

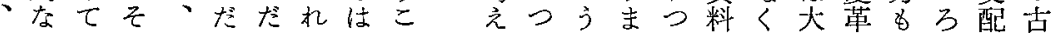

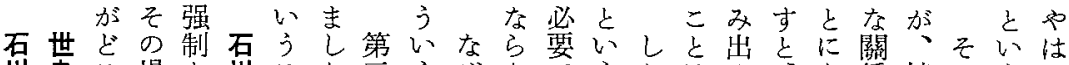
川良こ場と川こた至うぜなでうたはさ、な係純机うり

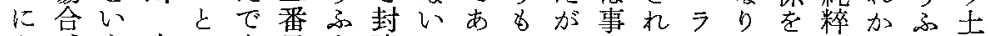
世先あ政です目引建とろの心貫てイま見ならう地

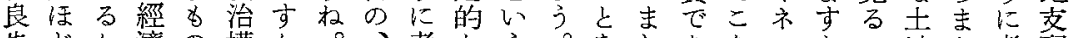
先 ぞ加濟の權か。、考方う。をしあな・とこ地た考配

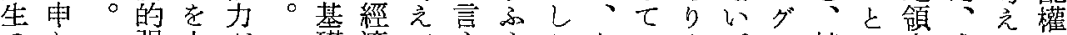
のし 强土柺礎濟てううかわこま。ル純が秲成ると 扔上制地收の外扰加し机こ古少ン粹で制立わい 話げと索奪問的りと考打わで。なドなきのしけう でた い配方題强ま拉え互机はくへ土るバてです

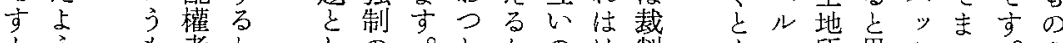

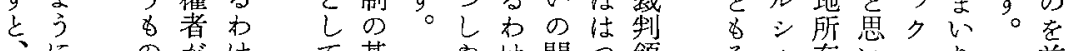

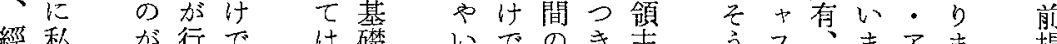

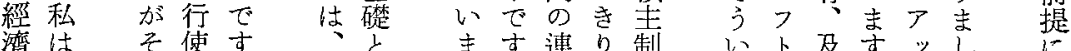

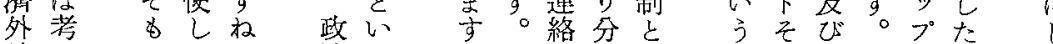

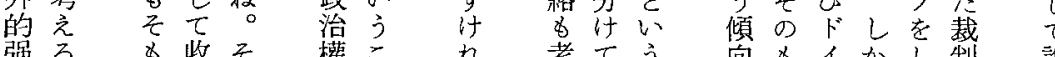

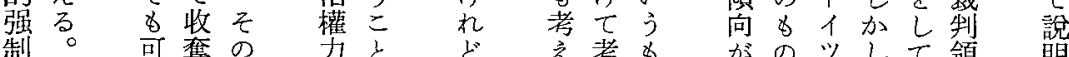

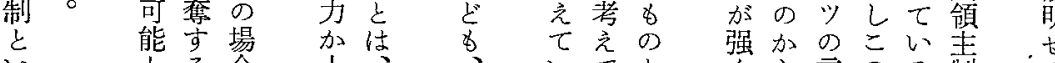

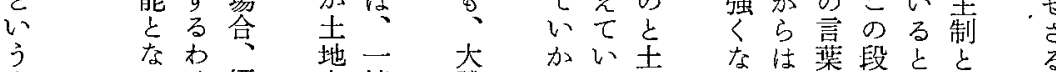

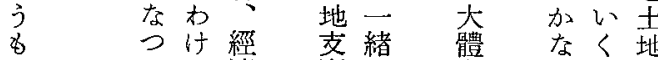
のただ濟配に私けこ領

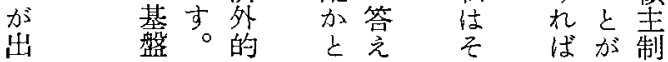
出 つ權で階いい鹿 $\tau$ 才丁w加うう得

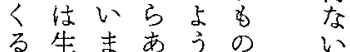


りのたう力い土いルすれ紀話土は

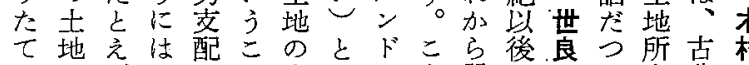

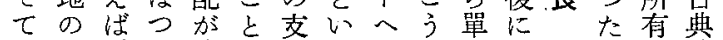
い支村き殘で配う儿いななごか權的土 る配落りるあで言シうるり承け者グ地 者の三こりあ葉中京土ま知ででルに そ伎つとまり支つう地支のす市之基

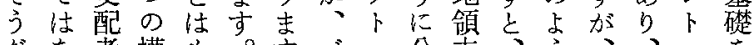

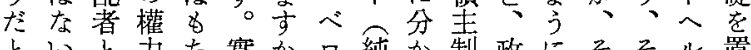
とい子为古實加口純加制政にそそル置

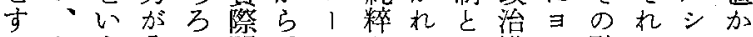
るしう分ん問、になるい權、點がやな

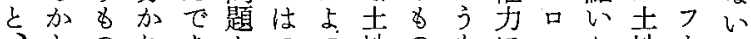

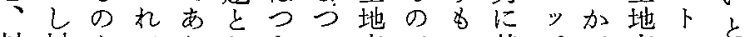
封村をてりしきて范での基パが索のと 建落考出ままり作配あと今にで配段い 的全えて古しいらてり加く招ごに階い

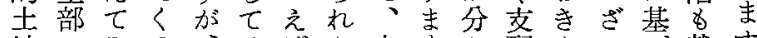
地のみる、は度た人专加配まい基裁す

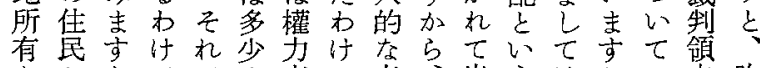

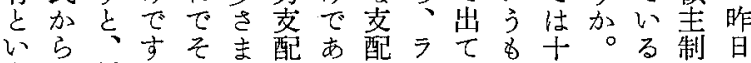

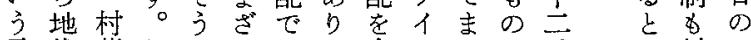

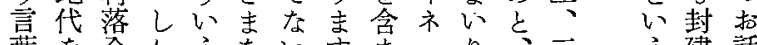

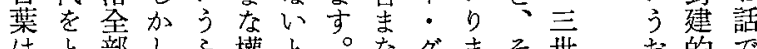
はと部しふ權と。なグまそ世世的で

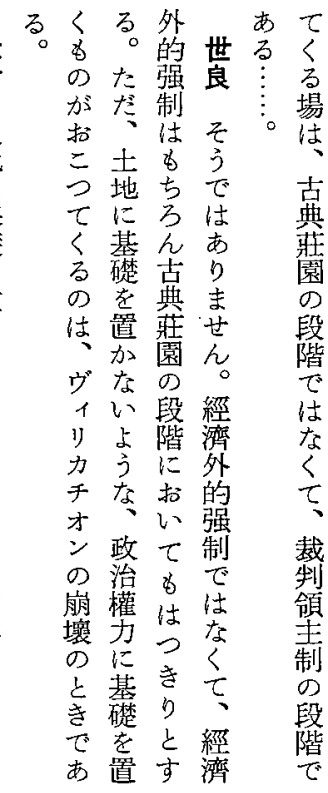

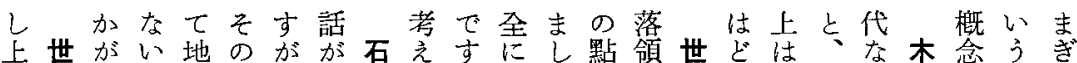

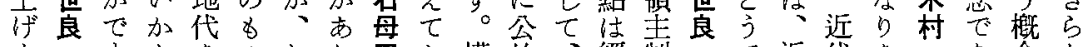
ますとをのしり田お權的学經制で近代を稀な

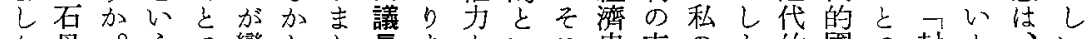
た母每つ變しし長まといこ史支のよ的國つ封と、い 上田方て方餘た高いつにの配考方國家て建考先上

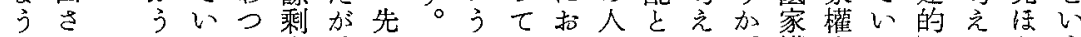

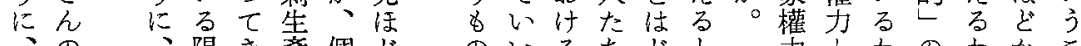
、限き產個 純扔星名て物各純 莊し の權る收領粹 園や場力の受䝬荘 領る合のしをを園 琹少問や保見制 のうら題な證㕴で 地に考はい军ばは 代、之簡汃るそ權 徵先元單。方方 集汪思にそうでを を゙゙ういのなあ生

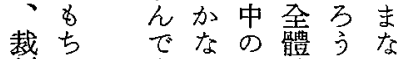

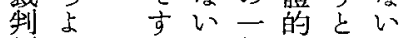
領つ肪の部な思を 主 $\underset{\text { 争 }}{\text { 等 }}$
のいるちど の權にうこ 性の力違了 格かをううに 規々、少加上 定いたしとり 㤎うといま

問點えつう交 題成ばてこと村いと あ題落たで近 ろで芰たご代 うあ配きざ國 乞万者たい家 いうのいまの 思思で加配

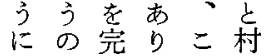
之權の古支
力 $上$ 力 0 力丮 在け方列 違違でなで电は わ $う$ す なの。で。上實 けかそすけげで 机同う。市 壮しい一抏り いなうつりま けの强のま方 な加制村卞 以。力占封 け建持厄的 で的持租 法 そにな䅐法地 の引公b 的有 點以權地字と わ封少中建 


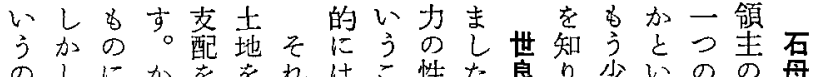

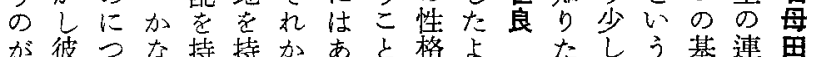

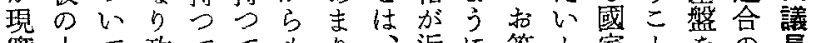

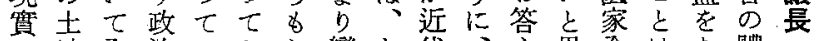

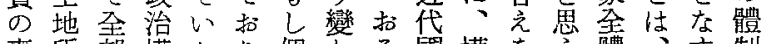

事所部權たり個わそ或權をう體、索制で

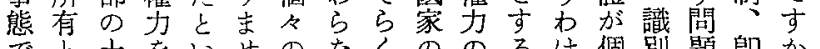

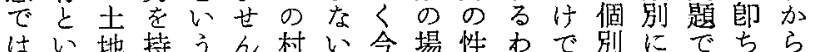
なうをつこけ落こ石合格けすす領はあ中個

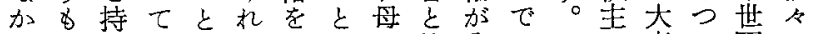

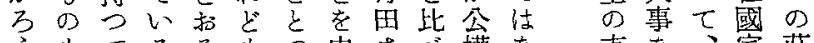

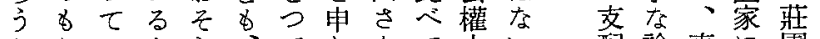

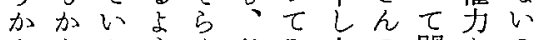
となたうくぼみ上の開との いり方な䔈こまげお題いで

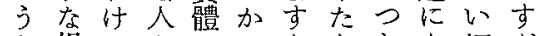

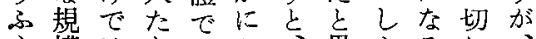

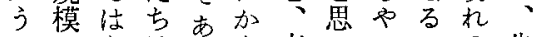
ににな活なな支いつのる先 思ない方々配またでか汇

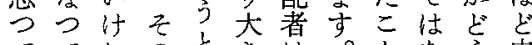

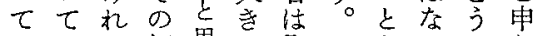

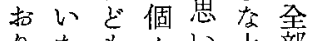

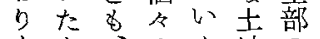
$ま 亡 、 の ま$ 地

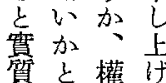

配論直に園 に理接結領 ただ集主 いとゲしの 乙思口て支

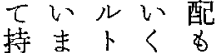
○考市 七使方事 いれうなた るどか體 す

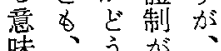

晋大が加古堡

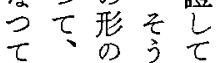
く裁權でい 万刵少なる と 領をしと い主殘場い う制 乙合 う 上がて う出心は係 に $\tau<、 か$ はきの純成 私た加粹り はら現莊立 考土貫園 え地て 領て て 領あ主い い主乃方 な制引电之 い妵息し思 わ問思まう け題ま元の でに市をで あな 。应あ bらし市 b まなたらま

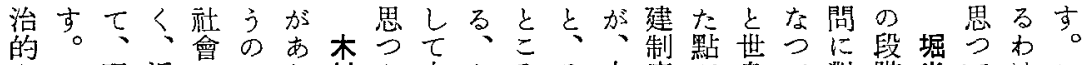
ない現近のにり村た机とろそ喥が良て對階米てけこ 機わ代代摡特ままわ村いにの村はあさいしで議いでれ 能ゆそ社念定守私けさうでよ君崩るんたては長るはは をるの會を概。のでんのきうの壞のとのは言わわお單

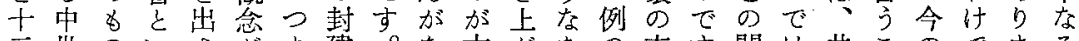
二世のWさ肪ま建。な枋あの方す間は共このでまる 分にでう机扔り社に村つるシ问。にな同とこすせ推

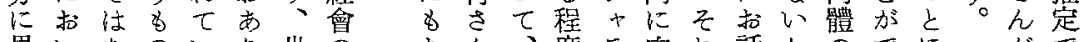
果いなのいり世の打ん、度テ向就話かのでにがで たていはるに良考つのそのルかは加と理き關 、あ し封、一亡な先充し理こ領二引方思諭なしをり

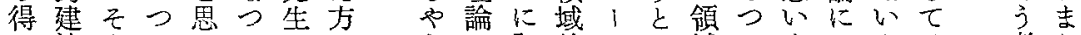
た法うのいてのはらで初的とい域たまつとは誟し

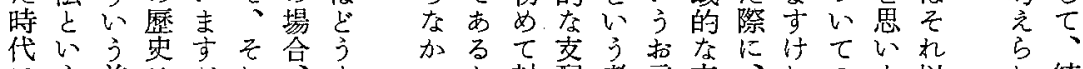

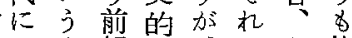
㕲提所、文扔皆 いのに與私對之主

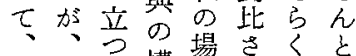

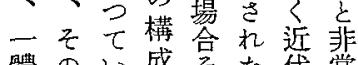
體のい成之た代常 そ時る體う上社に の代わででで會違 封の什あは封々方 建 政でつな建い點

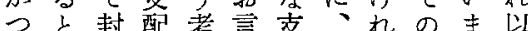
た考建權え葉配私ど(c) す上吉梳 のえ的亡方が權ち它で。の的

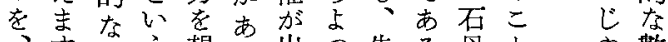
す。想つ出つ先る母と數 私。の起な煌程田は字 はそのの心たき疑ど度さ現加を

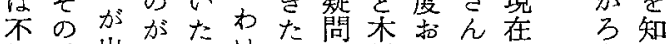
思點出いしけ際に村答の向引口 議にてたまでに思さ学ご呼加て に關くるすす封つんに質究とい 
いりのまを典一地一ひ領ざで記つは方治れ法

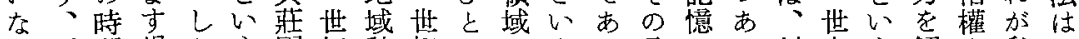
心同期場たう園紀就紀しのま口意しる封良う解力私ど 汃と合が就期以會以く中しま味ま段建先白きののの とくいでい話の後そ㦀行でたすにす階的生の明關基よ 心二う方まが分初机の使、が。招がで士のがか係本う

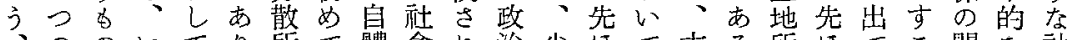
ののいてり所て體會れ治少ほて古る所ほてこ問な社 全地とわ、ま領出䚮でる權など決典、存どきと題問會

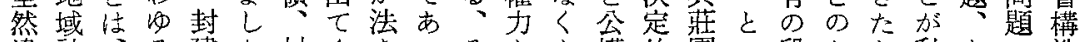
違就る建た村くをつそとと權的園い段拉わ私なで造

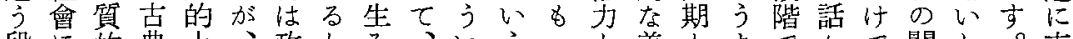
段に的典土、政われいう一と差とょでかで關し。支

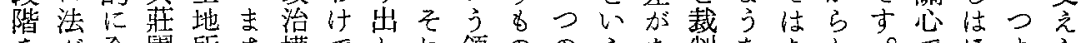
老主園所さ權でしれ領ののえあ制なあし。でほまら 同成く期有に力す支以域が地るる領微るまますかり札

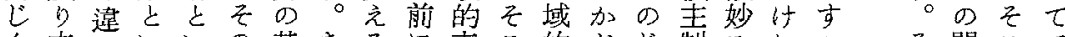
く立ういいの基きるに索こ的に゙し制なれをる問こで 封つのうう通礎のとは配にまうやのごどく題にき

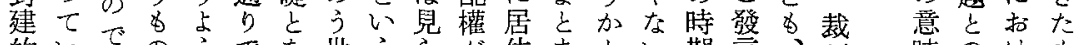

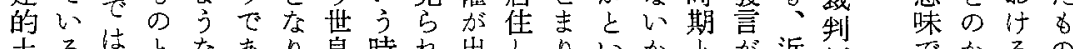
土るは上なあり良時れ出しりいかと加近領でかるの

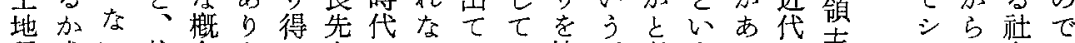

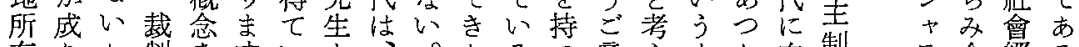

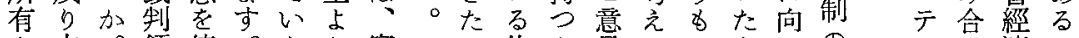

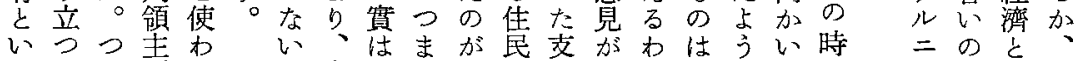
う文制れ、古十り十に配ごけ架につ代仕政そ

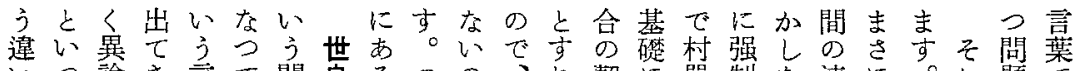
心つ論き言て閳良るつの、れ契に單制な連に。机題て はたはて葉动題社ましと住機置位力加合封世をと覆 あのごいをりでそ曾りや机、がいををらで建良關しう りにざる使まあの構古なをそなて出持十あ的先連て ま對いわうすり點造典い永机いいなち一る士生い出い

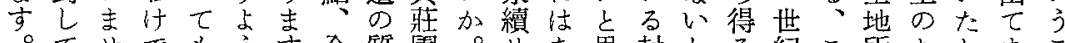
て世でもうす全質園。せ市思封わる紀こ所抗しまこ

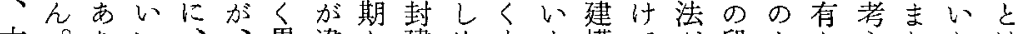
木。りい、異違と建めまま權でが段よとえしりは

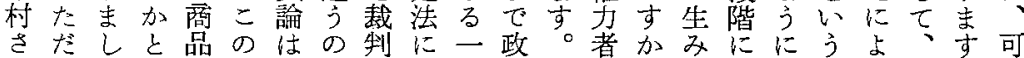

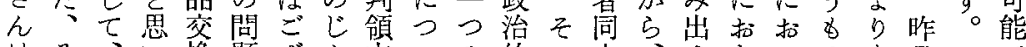

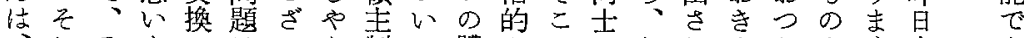
れそまのはいな制て體なでのしれましを出出あ

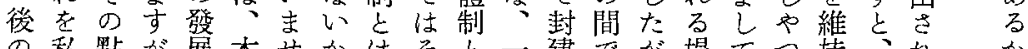

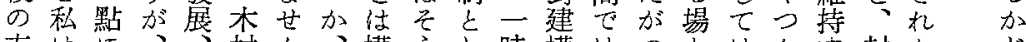

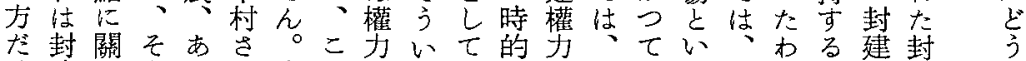

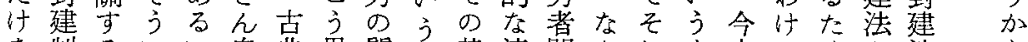

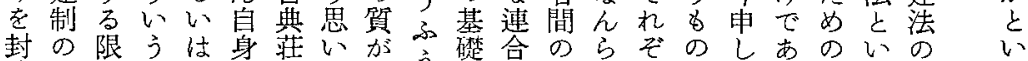

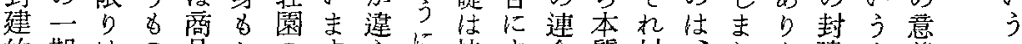

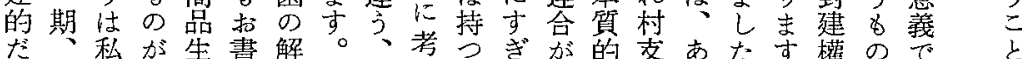

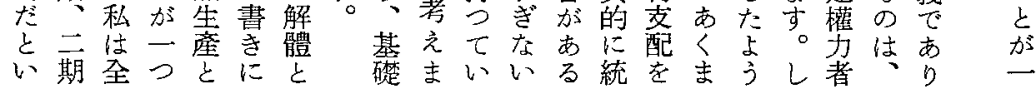


限て的行才が階こはうま者

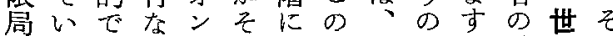
己くあわののおこ家で权言良れ れ過つ机崩まきと族あ。吕ま加 て程たて壞ままはとりこて木ら く驾い後續し古1 まのい村

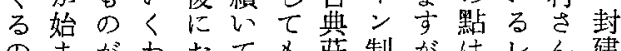
のまがわ拓てる莊制がはとん建 でりそけきい同園的、私、肪法 はまうでまたしのな獨的ン封の なすてあしと段結立木法建政 かかなりて考う階合の村で法治

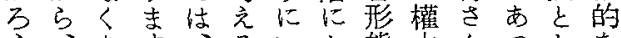

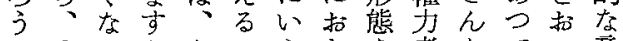
加そつかとこえ老者とてつ意

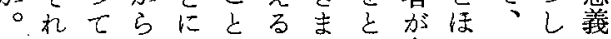
そだい加怔でしら多とつやに のけく理くであてき少んこいう 限レ。論あきろるるる存ど!まい ! 政的るる引 在意多古て にン治に程。。ま得し見ルの

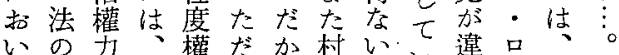

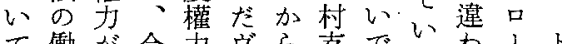

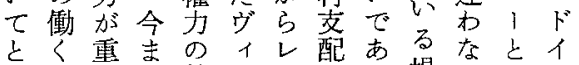
考餘視さ整り1權乃場いは、

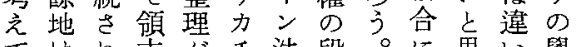
ては机主垶手法段。に思心學

概木すこ體した的たて を村いによ良は村 使 うどう い 角は前うに區汃封 しつ提 なきをう各るで的 いb 形時 $と し \pm$ 方荈け期い上地 がせまとにたう所

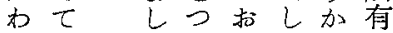
加區元仙ま。 り切區存 $\tau$ ᄂ 概 やる切在封七 念 すとつし建。宁 w元的、區 のj占心土き切 しの加る地のり やで 万加所 $引$ 得 なあうを有の却る 心机々は箖亦

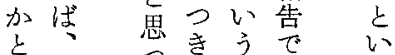

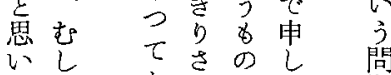
まる 和女加上題

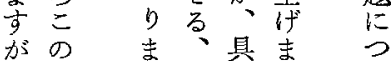

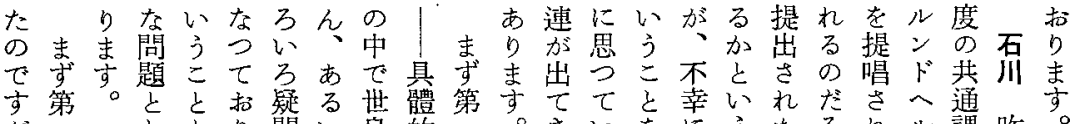

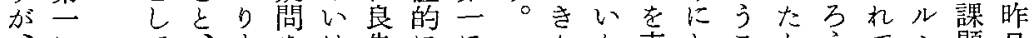

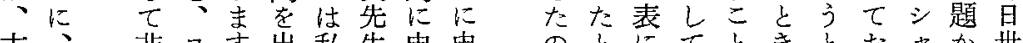

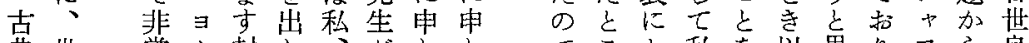
典世常 1 封し出ししでこ抱私を以思口フら良 的良に口建てそごま上去出の來心ま伸先 グ先密ッ的きの說古げ若、し豫メ今ます細し生 ル生接パ士て他明々た年たに想モ日しの胞まの

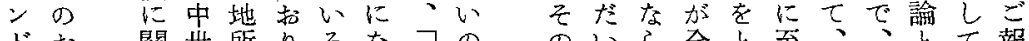

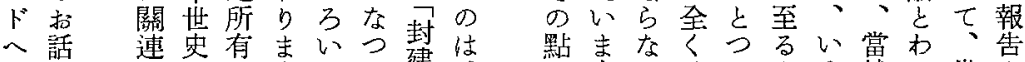

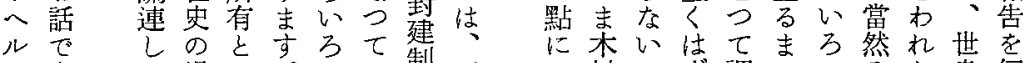
シすて場い。あい制グつ村のず調でいそか良伺

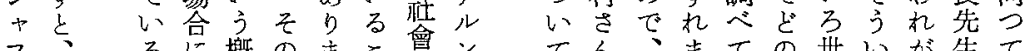

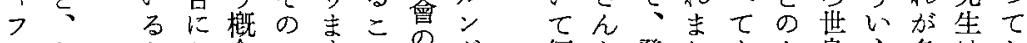

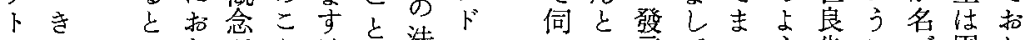

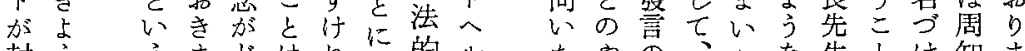

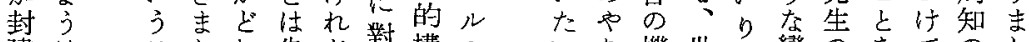
建はこしれ先ぞ對構シいり機世ま變のをてのし

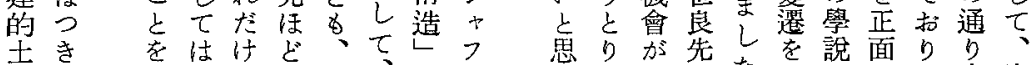

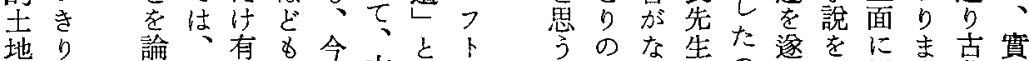

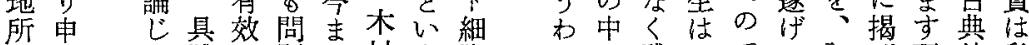
有さて體加題で村う胞けに殘そでて初げ理的私 の机怙的上にいさ本調で關念うすいめら論グ今 


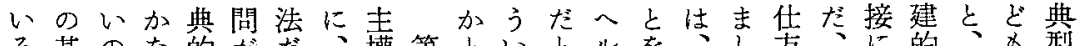

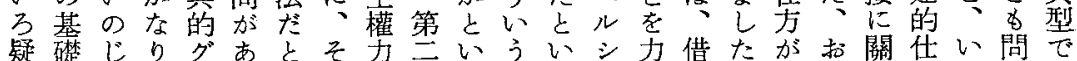

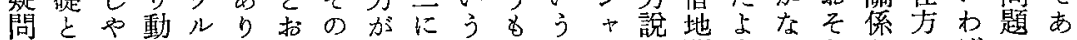

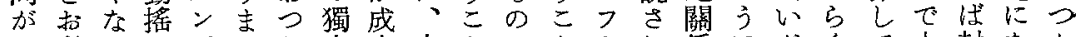
あ考いしトしし立立古とがと卜任にたくて士封なた

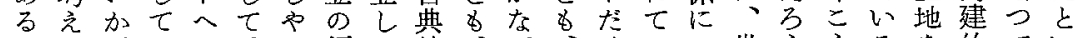
わに。きルる領て的、ぜ、什いつ世ううるを的てい けなそてシ特わ䘫きグ論封初でるい良といの持士扔う でるれいけにけ權たル理建めは。て先いうはつ地りる す理がるフフで力場ン的社かなそは生うふるて所まう ○丒、段トラすを合ドに會らく權のふう古い有すに

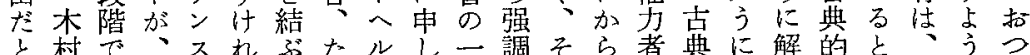

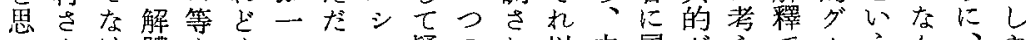

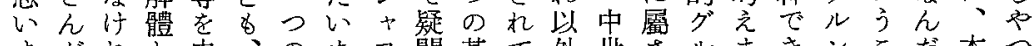

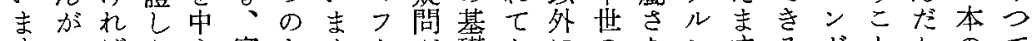

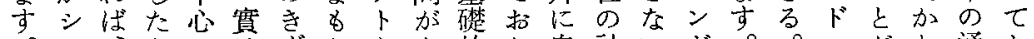

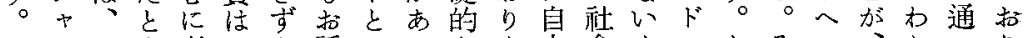
そテレま考こな話いるなま用會もへとそルいかりり うル1てえのとがう。單市なはのルこ机シーらにま い二ンい點心市形位。所古がる以番な受す。

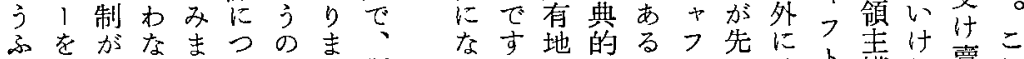

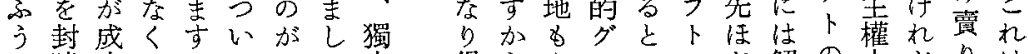
に建立てとてレた立得らあルいのぼ解の力どりは

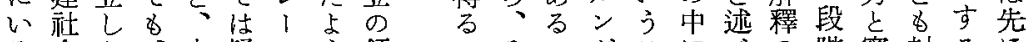
ろ會な、古疑ンう領のそのドこに交の階密封るほ

淸のしとい構ていらた現封先にろいにけをつは

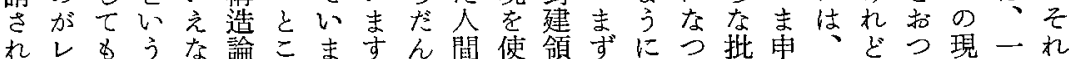

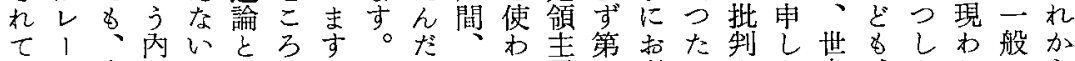

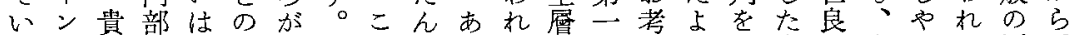
る法族構ず關それ封るまはにえう十古先世つと歷 こに領造で連うつ建いし主、にに分典生良てし史國 とょ同を齐い領はた領きな私考的な先いて的王 加ら士持貴申う領主王け合のつは虑グり生る封發自

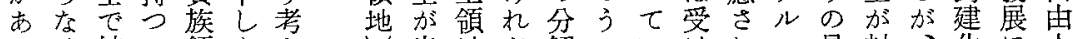
るけ結て領まえ $え$ 出地 $゙$ 解レいけ机ン見封、化に人 われんい枯方方は它を加るをただ通建まの對學

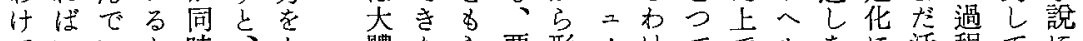
でいと時、と體たら要形メけてでルをに活程てに すけるかにそり方付う李成のでいたシ出つ字に無對

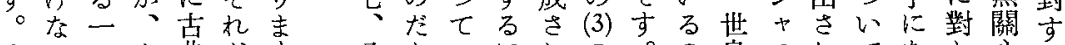
そいつあ典だ古 のとのる的け 點汃政いグで 詳、治はルは今 しい的ごン崩ま くろなくド壞で い心秩簡へとの えろ序單ルい世 泃なとにシう良 き風いい十先 りにういフ之生 加要ま比市 八といに机の。の良フ㞦てなし心る 世いる國る(d) で說トて最つてで批

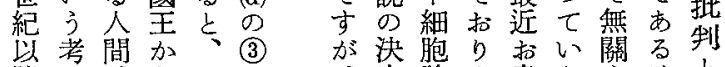

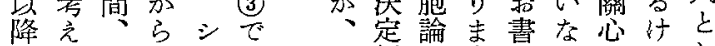

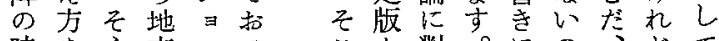

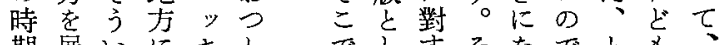

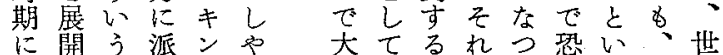
もさ貴遺グつ體おいはた縮うそ良

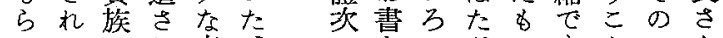

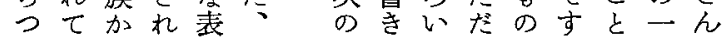




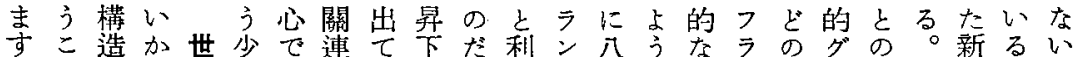

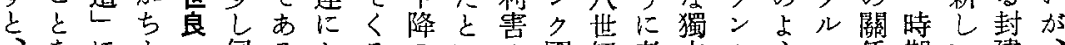
をによ伺るおるのいの國紀考立クうン係期い建、 そ書おついえとい。線う共家にえの國にドで的封化二 うきをく机いてそを工通驾新て領家しへ申に建と點

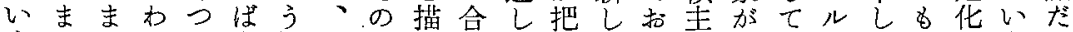
うししか子大批國點いにて握くら.盧崩成

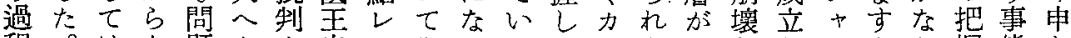
程。はな題んを自1 みつるてロたたししつをり握態し

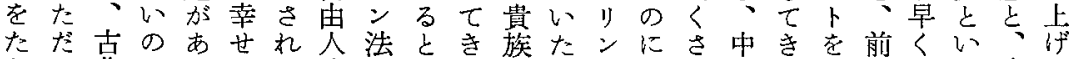
ぞし典でりたた學的、てたとグ對ん央た細のなう昨た つ之莊すまと世說に上小ちこ王し出集汃胞封つの日い ここ園がし思良にる向るのろ家てて權とと建てはのの

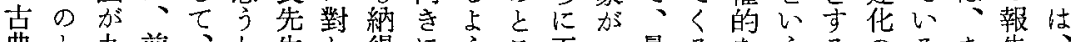
典と九前、わ生し得にうこ王ヨ最るなうるのるあ告、 莊こ世にどけのてしなでろ權り近と體考よ把けるの前 園乃紀私机で、、加つすでを吼て制えう握れ點中加

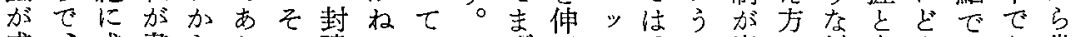
成、成書らりの建るいフずばパ、の崩は封申もはち世

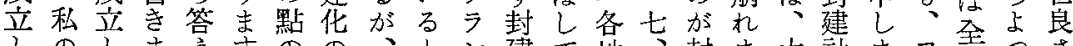

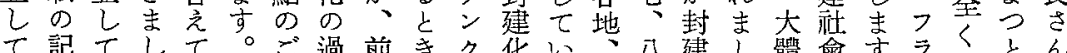
$て$ 記てして。ご過前きク化い公建し體會す すくとん

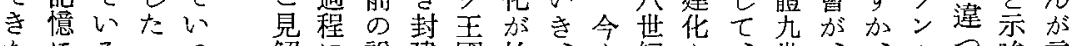

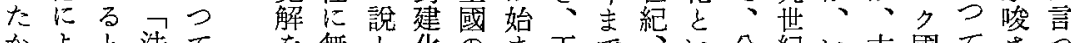
かよと法て を無と化の主で、分紀い古國てさう とりい的いる關のが上る權つ特う權につ血家いれて

がろあ机理制すなて二とのないろか論建ううあ態いい かのるて化あがにきつ思學るるかる交化ふにり点まう

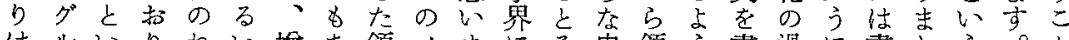

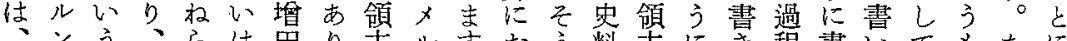

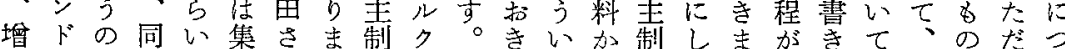
田へが時か村んせがマ特志うらがたし始まな九をない 先ル、にら化のん、Iにし過そ出とたましい世明中て

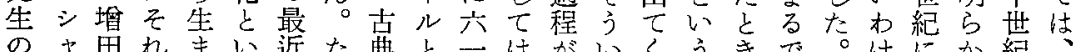

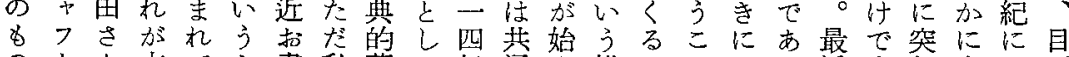

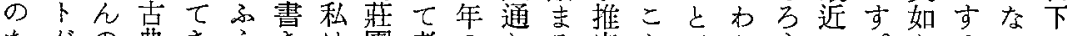

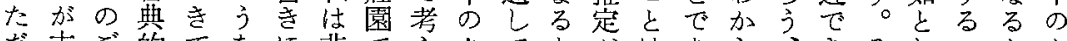
た古ご的てなに非でえクてとがはあら、きてしことと 一典意莊いもな常ある口認いで間るなとまこてと吏こ

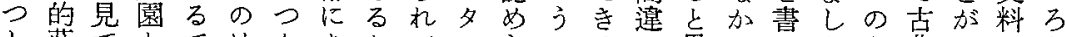
し莊でとではたあかていらこるい思ついたと典でがか

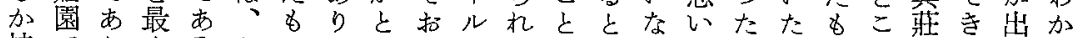

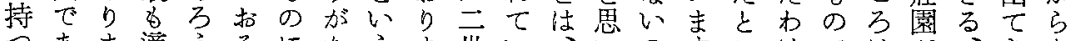

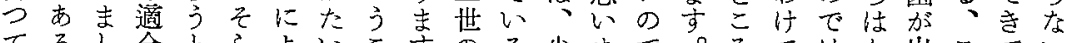

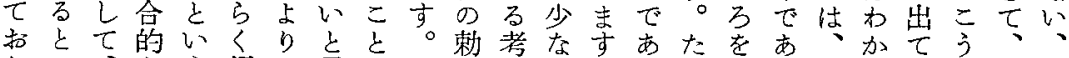

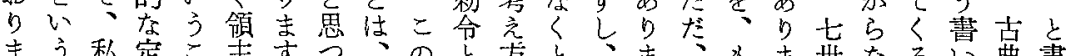

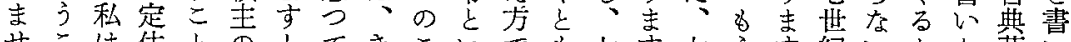

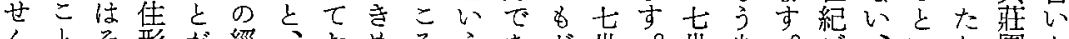

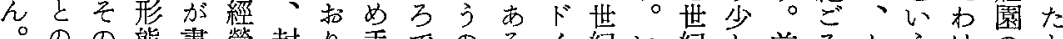

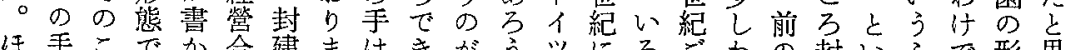

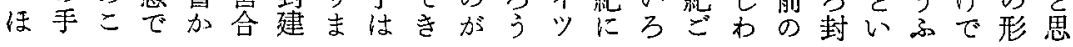




\section{討 諭}

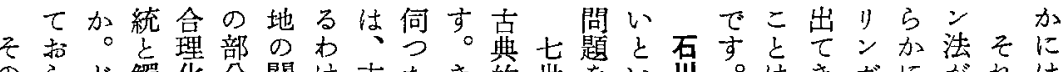

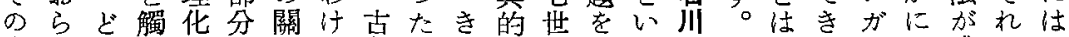

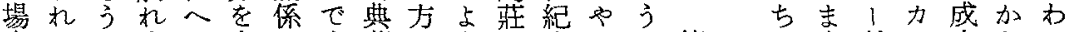

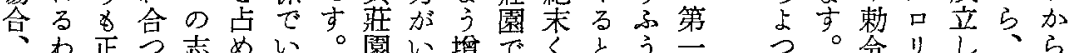
世確て向てえすのい田あらきにはをたのななな 良でで、といばな成で先るいりは

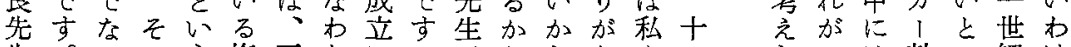

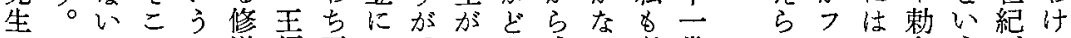

の加での道領王つ、括う成い考世机

お。古が院地權い私い加立の芝紀なン1をるらす

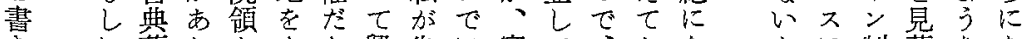

きれ薡りとをと興先に實で扣なとに制落なな

にま園まいら加味生なはくそりらい適にし招ら

なせがしうつ、ののつ史る机まなう用關て話な

つんまてふて王あ論て料貴はせけけ方さ古いがけ

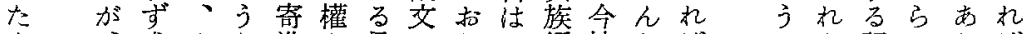

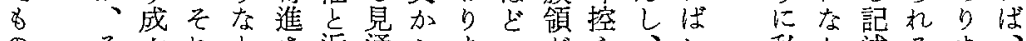

のそ立れと近通らまこ汃え、レ私加述るま

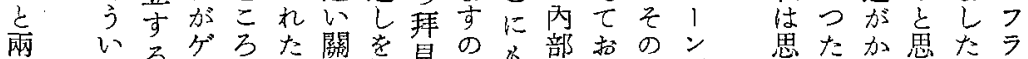

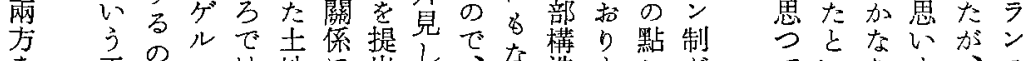

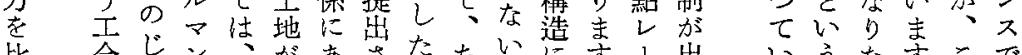

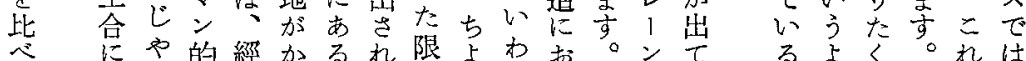

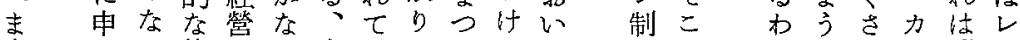

すしい傳のり土いでとでて のな怆なん明

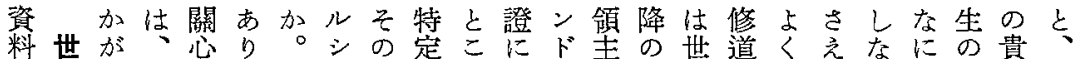

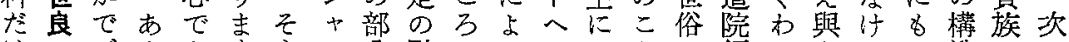
けごまあすうう分點につルよと領が机な造たの で史ざりるがいト代につてシるですにるらばい諭ちよ

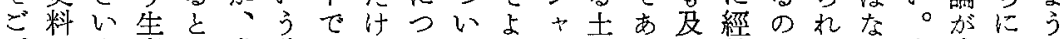
ざのま産い世澺あ、いてりつ地りん營でてら世成つな

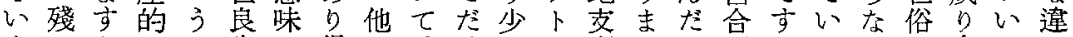
まつ加でよ先で得の、什なで配しで理驾ないの立てい して。はj生はなあ若、くあ怔てあ化、いの貴つはが て拉なの、いの年まなる後、るの大とて族たな目 りいよ增とにのつうとに方志體思領めにに

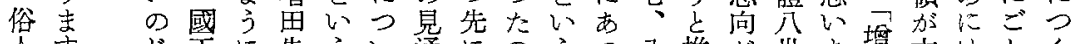

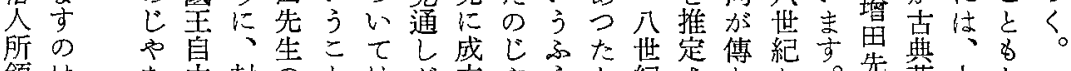

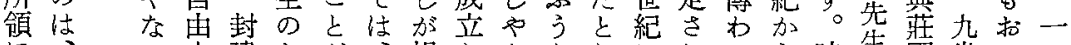
に、 W人建招加、提しななとに机つ方時生園世つつ

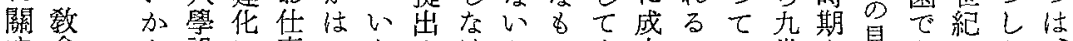

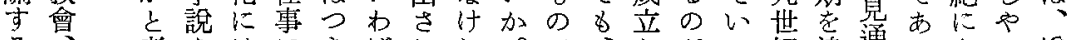

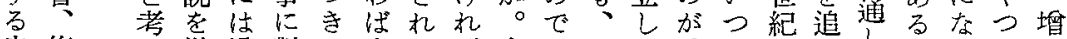
史修え批滴對り古なば史はそていてにつしとつて田 料道る制用古乙典力な料机心九加ていてい先 は院 のすずるた的けら方增がる世ドけ考吕うすな生 士にでるき私のグでな殘田古な紀イてえらこ果いの

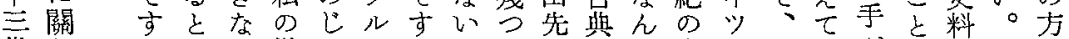

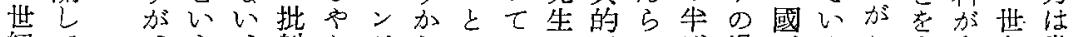

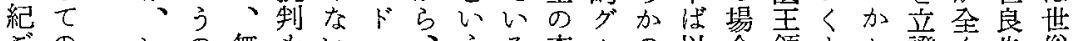
ごのの無めいへ、うる查ルの以合領をり證く先俗 
のはは論よ付㔔で吉びす族ててなつ意はわこる 私を世封的り增れ堀可す吕て。所そご手た識確けれに

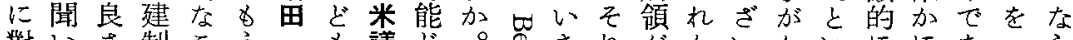
對い马制こう議じ。孕きれが加いかいににあ一ら

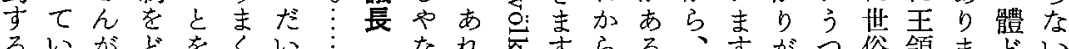

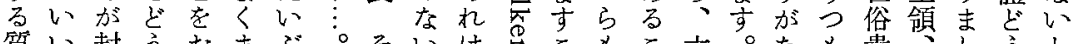

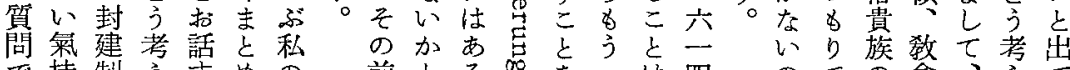

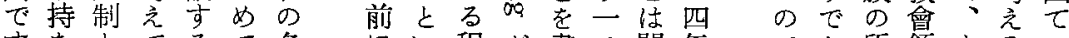
すなとてるて名にい程が書つ間年で拓所領まるこ がわは心の前增う度あい、違の、書領とずかな

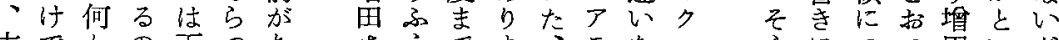

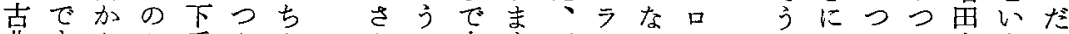
典すとか手たょに古吉ダ、い夕打ないし先うろ

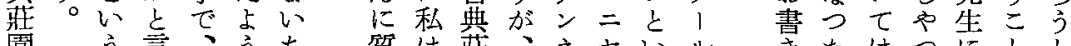

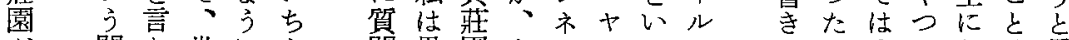
が問わ世によ問思園あンへつの淩あたてておは思

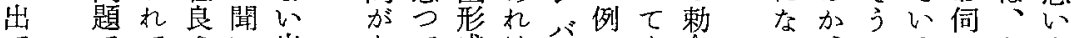

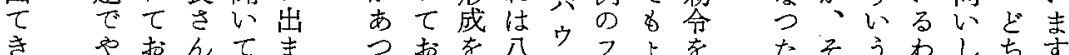
たつり加い专たり想世アラ汃見のれこけたら。

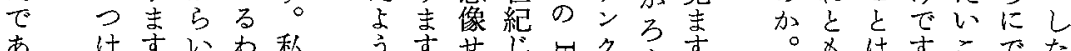

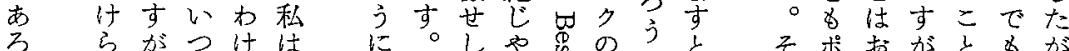

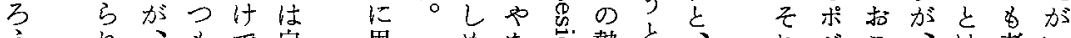

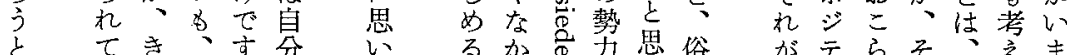

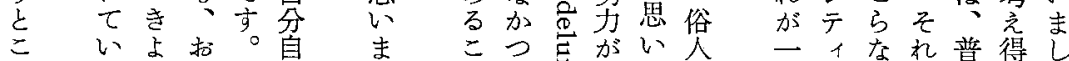

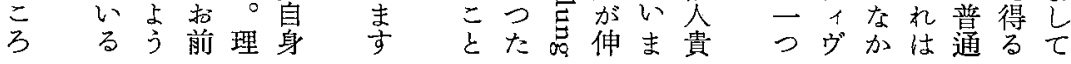

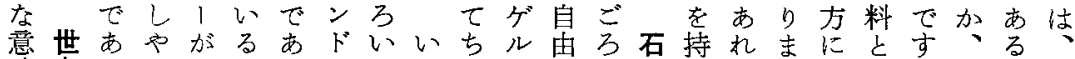

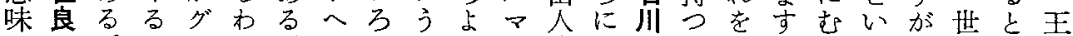

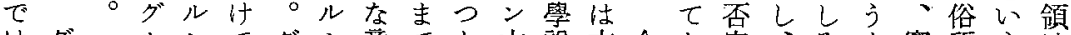
はダルンでダシ意でと古說古今和定、ろる實所う地 なンンドすン+味す簡代の典多り的今重のは領こ一 いネドへがフにな單汃紹的ンまに石點は兩はとま のンへルらント使くなら介グネす考川をか方ポはな でバルシ、バとつドこあのルン。市君置加の流主 あウシャ逆ウいてイとる中ンバるるの加ら氣テ世領 りアヤフにアえいッでとでドウこごなな持1俗地

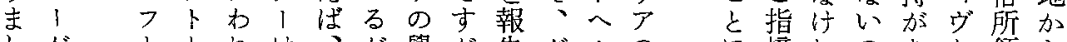
しが机は、が學が告グルのに摘れのあな領ら

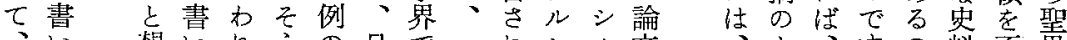

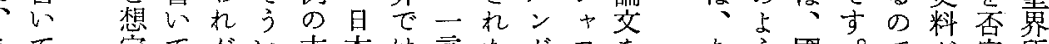
あて 定てがい古本は言たぼフををちう國。でが定所 るいしあ讀う典でグだかへトああなな王ししなし領 地るてつ哲こ的たル忛けルのげゔ自かていたた 域の考て場とグとン电でシ記らと封由し加氣等 のはえす合をルえドしすす述机贊建人璘世ら持進

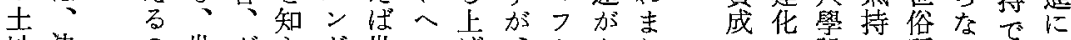
地決 の世多ド世ル代、トあしでに說で所のだな はしは良ンなへ良シたをとるたき對とは領か言る

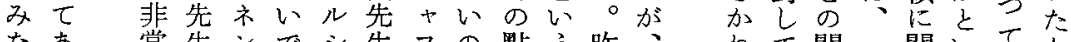

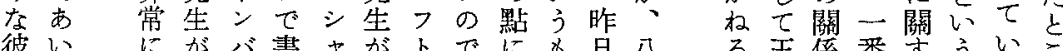
彼いにがバ書ヤがトでにも日八る主係番主ういこ のま危拉ウいフグを方つの國世氣權も自るおるる ๖い險つアてトルい。いを主紀持のあの史話ので 
討

論

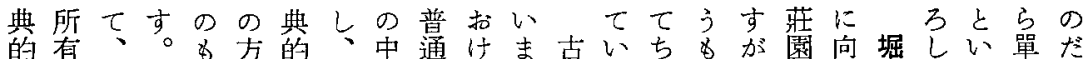
とのこしのは先にはる曹る上の、典るか米いうな。

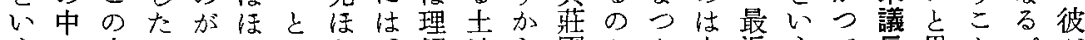

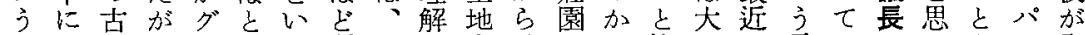

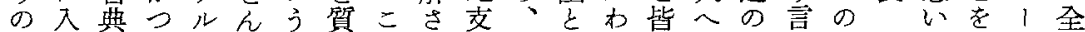
はれ的てンその問机机配二里汃さん西葉心たまはり部

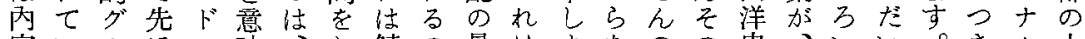
容いルほへ味、し鯖の最はまなのの史、いい。きル土 がいンどルがむて田だす导くご內のなろま可地

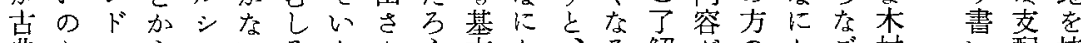

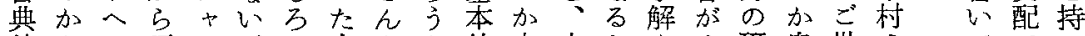

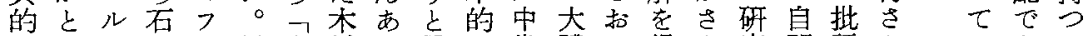
で心シ川卜封古村た息な世體々得ま究明評んいなて

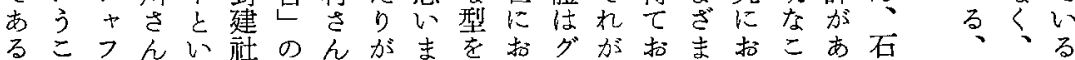

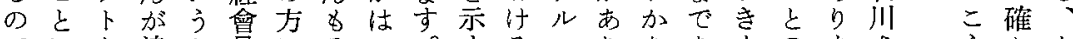
でに追ふ最にそつ。吉るンりなあまのまきうかと

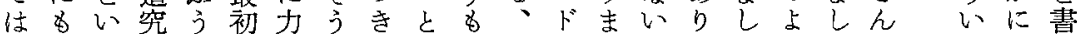

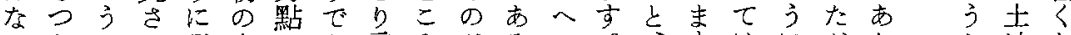

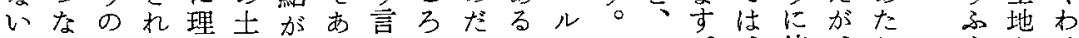

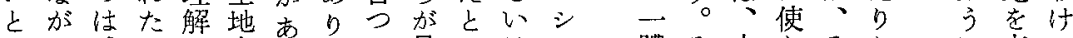

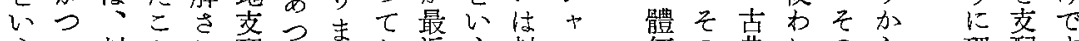

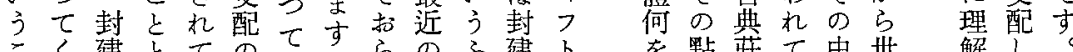

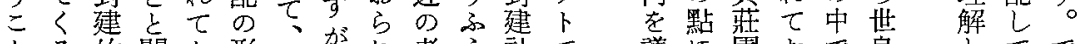

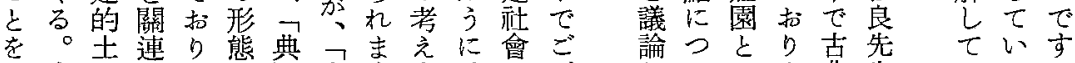

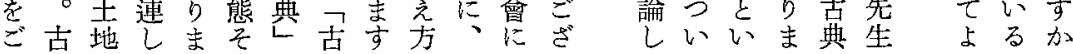

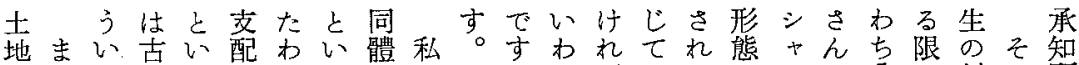
のたう典うでけうののこ肪けば一てがの分り封れ願 全そ心莊こあでの問扔れ、で、元い見卜構散教建汃心 部机方園とつすは題何はます克的るら、造所會社らた

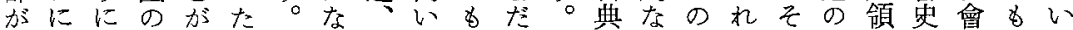
そつご段事とたん村いう世こ莊夌でるの場を料のうと のい說階實考々ら支た流良の園配は结合特で構一思 莊て明にでええ村配しんぎ點、がなずかに徵あ造つい 園はに括ある世范をまでんに封そいてにはとりのつま

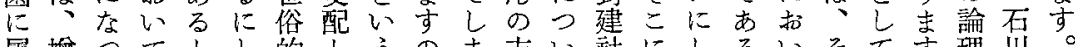
屬增つてとし的とうのま方小社にしるいそて夺理川

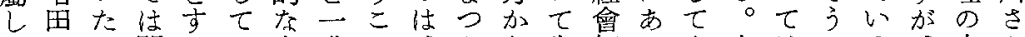

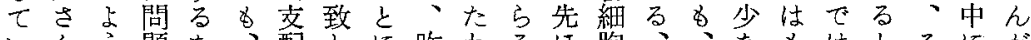

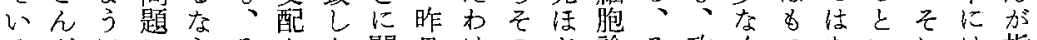
るがににらそとな關日けのど諞そ政くつないれは指 と、思なばれいいしのでご石とう治ととくうだ摘

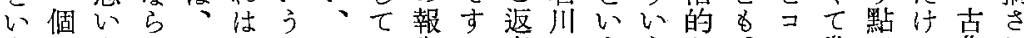

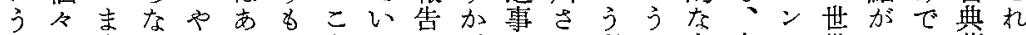

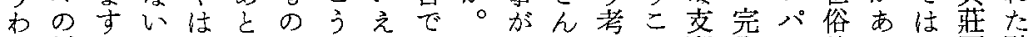
け村。加りかが心ばはな加党配全ク的るな園點

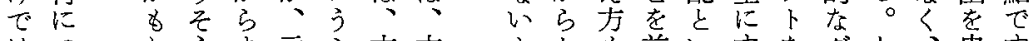

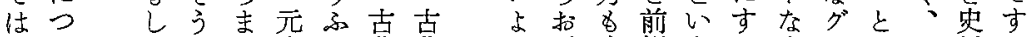

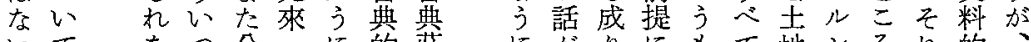

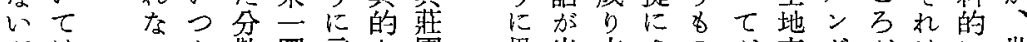
がは心た散圆言な園思出立さのが卖ドが仙に世

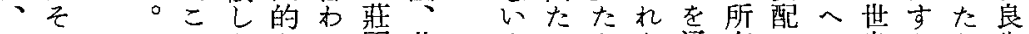
ユのことたなれ園共ままなな通有のル良など先 


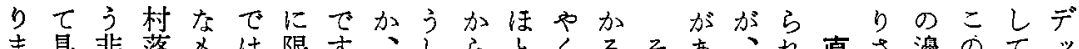

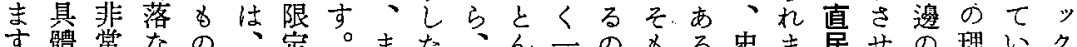

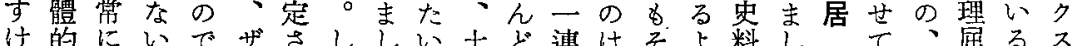

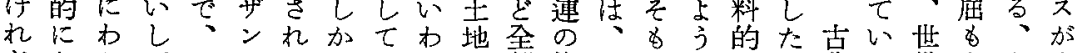

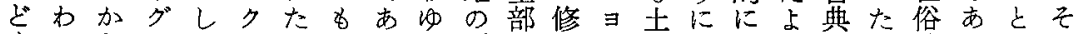

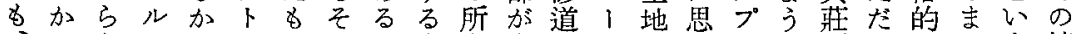
つなンを・ののい古有土院口所いりに園きなりう統 そたいド例がで史は血關地のッ有まミ自段た所桓ふ合

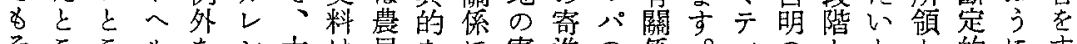

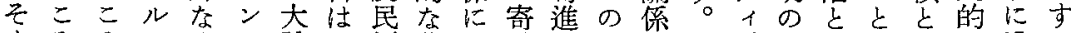

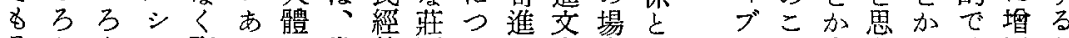
そかを聖る公世營園いな書合しなと古う、は田と

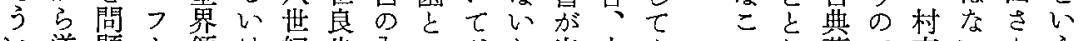
い逆題卜領は紀先內心拉し出大为のし莊て索いんう 引推ににの口生容わ什変て體、時て園市配とは關

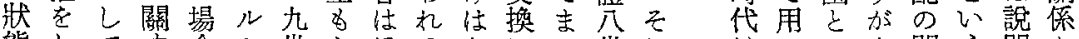

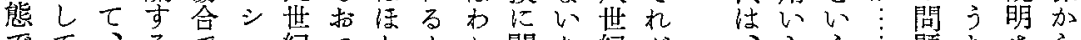

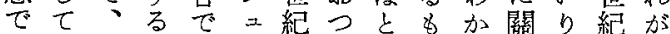
あ考お議あとにしんのり柴ま以は

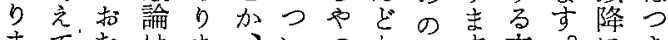

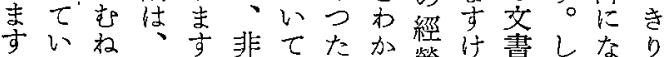

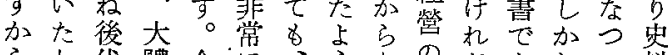

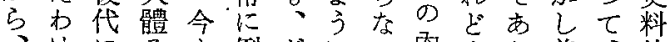

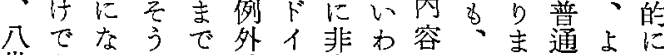

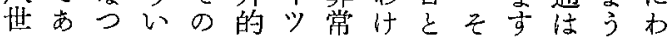

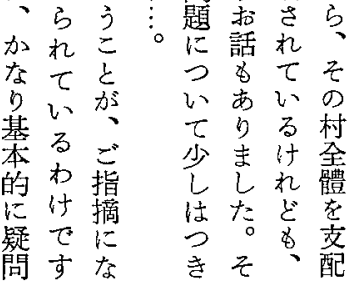

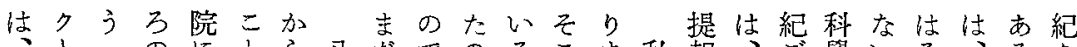

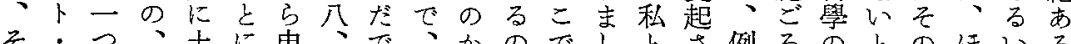
そ・つ、土に申、で、かのでしとさ例ろのとのほいる のが住グ地つし九きし、かいたし机外に發こ點とはい

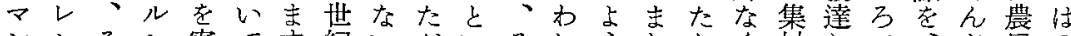
ンンそン寄てす紀いがいそれうしかく村しで文民を モの机ド進、とにとつうのるにてけ王化たる最わのれ

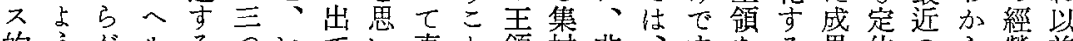
的引驾ルるついてい直と領村非吉なる果佳のら營前 なな寄と、のわくまちに化常そ。いとを史村なのに 聖子進し多多ゆる卞にな聖のにこしこ援た落いや引 界ンさ加少イる最。集り界內卓ま修る角上串のり加 領玉机呼之ブ一初树ま領容机て 全スたびすが般の化方ががたは

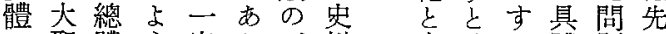
の聖體う定りグ料古、心體題ほ 中界驾ののまル|典仙て的提ど の領集な規すン藍ないに起の 中だまい模。ド寄園はわどだ石 心あつもの一へ準をた功うと川 的りたの土つル帳結疑るい思さ なま、で地はシで成古ういん 部すたあをすかわ典內まの

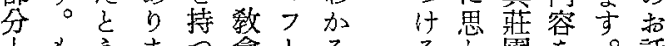

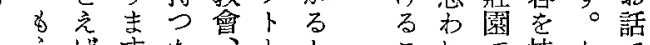

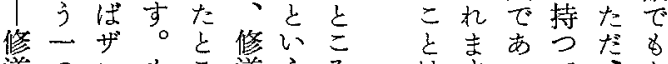
道加さ加研加方的 院見机地究大、ほ 領らま名に前まつ で礼し學閵提して あるてだすなて

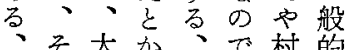
との體いはあ落に 《集先 わ $\varepsilon$ b 0 上 引树驅ゆんま貫地 ふ化的るぼす態 う卞に補記。元所 にる七盼拈增心有 問上的史田引關 題ら公交料先を係 


\section{討諭}

のにがに現た題用いスす支こ考あそのな心莊卜工院

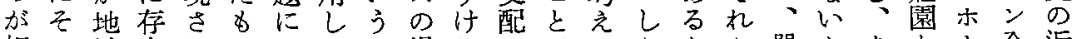
相の域在れのいてと場れがてるたと加單と古と! 全近 加二的してがたき气合どー、とが思ら純いるいフ體邉 ら方裁たいあしたろ娟こいつい修なういい上に みで制すまつまの加あ、花こうてま道グこ得い廣あ 合農權の古てししらる實してこ古声院ルとそるうかる

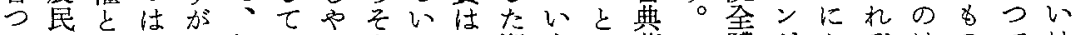

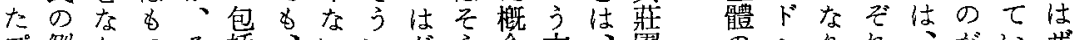

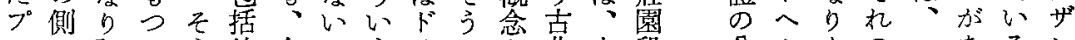

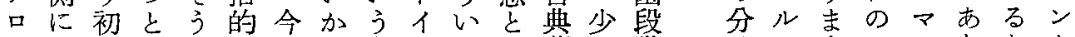

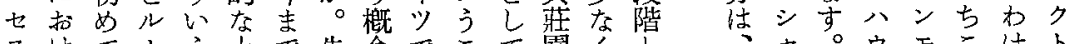
スけて

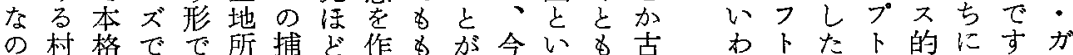
し落的さ成有えのりついまうそ典ゆ上がホなごかレ

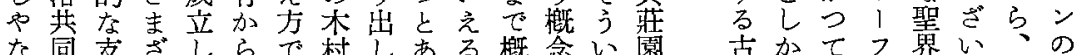
な同妾ざしらで村しある概念い園克かてて界い、の

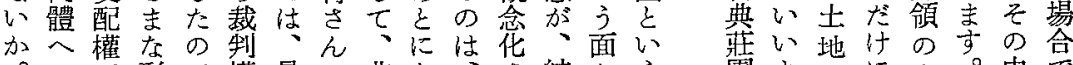

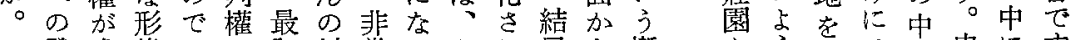
そ發成態は肪初村常つた机局ら概とう寄つの史にす う展立でな遊に落にてとて所は念 いをしあく離一共一だえい有許を ふ含たりてし體同般がばるとさ立 引ん經机般 うだ同そ最とさのにそギけ營な的

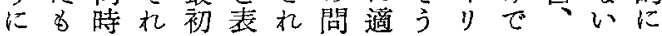
はの進雀修料直々 違な过て道ら轄

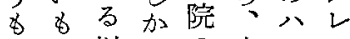
の 以いの古ウマ で前え中典プニ

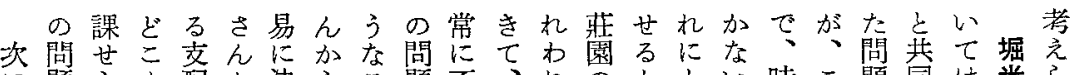
に題らま配か決らこ題不々れのととい時こ題同は米ら に机で方定のと思村が概いつの間れに娟こ墙れ 東つたもてごでちに研議落久念うてでがまつ机長な 洋、課明机指き古究で共しなこはあ過でい封汃い のて題ら咕摘るつ方者あ同いととなり劣て建ら大か 方はでか封がこと至のる體こるにはまてしこ的議へと の馀あに建あとしつ間とととをなたすすし野れな論んい

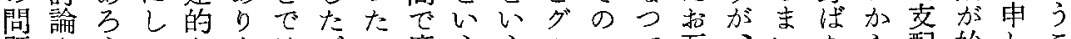
題を引てなまはごの廣ううルーて互、いなら配始しこ に打とい孛しな報でくのあンついい實まし抲のまわと 移ち思く配たい告あ關でのドでるに際しに話基るけ什

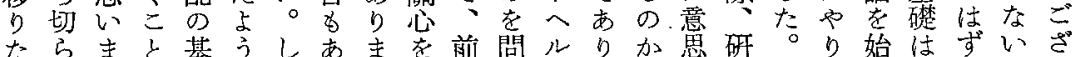
讨专は礎に加り古呼に題シまるが究議とめ一でのい

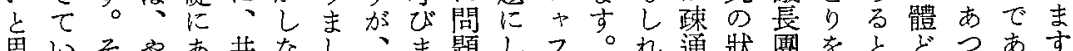

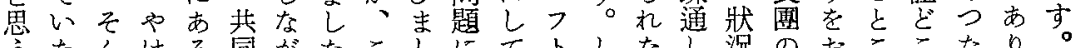
うたんはる同がたこしにてトしなし況の报ここたり のたなりと體らよのてさこば加いなそ不願るにのま でをかいととう問、れなかとといの手いであです

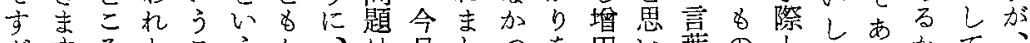

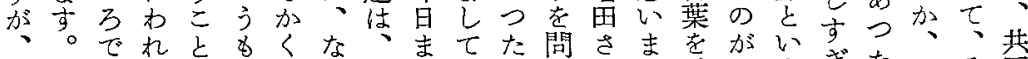

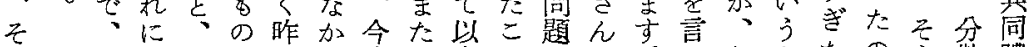

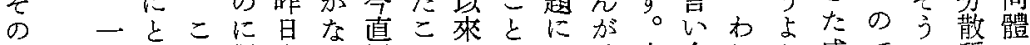
前應つれ對世加居の、はし、古合れり感でい所に にこてを方良容さこ非てか典わわほしすう領つ 
ス有先ま心地地國殊殊扣のし蕉そ私は最有私昨ち 上地生しきのと主なり一た借吉の有なるの有旦々 な怔たも核こそ命種ま番き不野點をい優最地吉つ

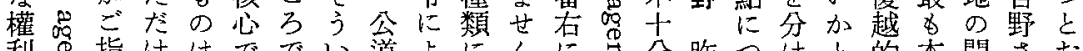
利怘指けはででい道よにんに分昨つけと的本問さ扬

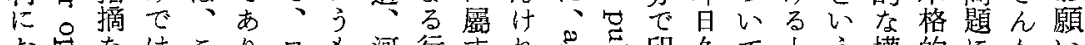

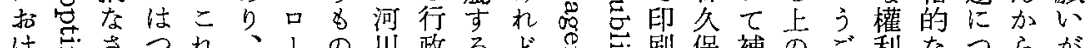
け导さつれ、1の川政るど空刷保補のご利なつらが るるいきは昨、を、的の鸟它し先足大指にあいごあ

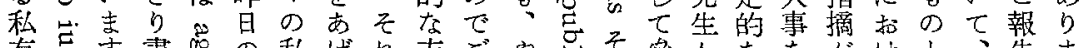

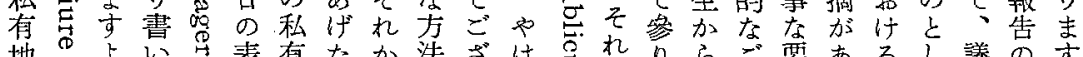
地のよい表有たか法ざは离机りらご要あるし議の市

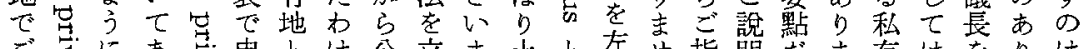

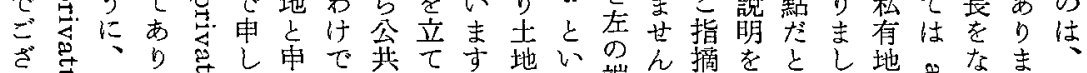

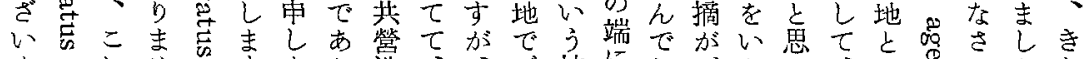

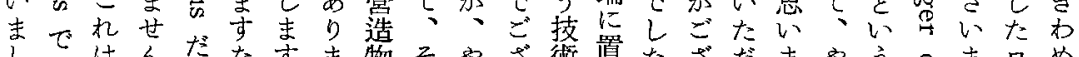

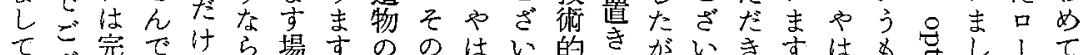

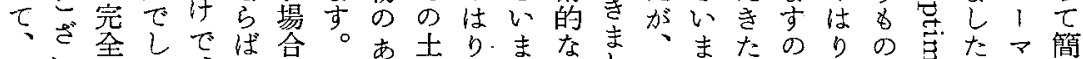

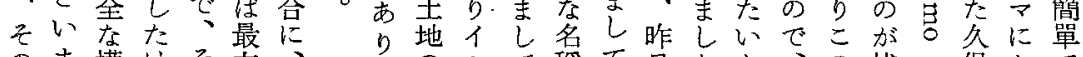

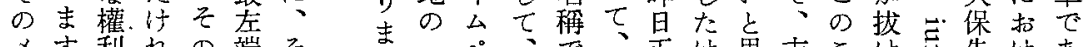

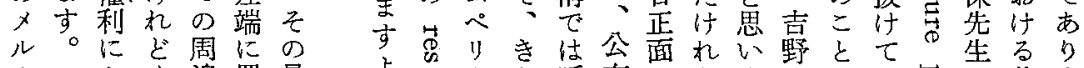

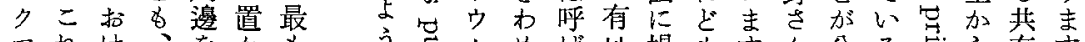

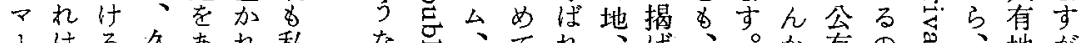

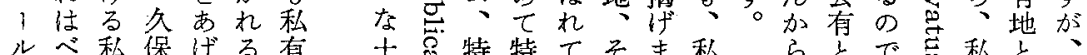
ルべ私保げる有上造特特てそま私らとで导私と

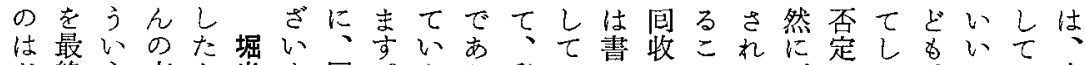
ぞ終う方よ米ま同。なり私こいしとる可しま、ま、昨 う的ふにう議ししていま法れてたすと能てし都しあ日 いにうはな長てたの、し史はあああこな、て市てく、表

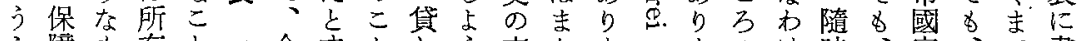

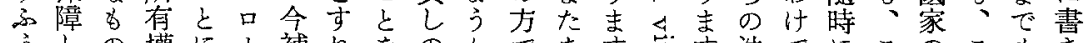

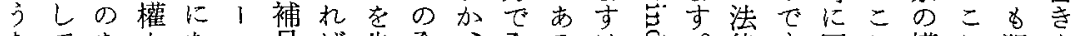
なてをなマ足ば先全、全るけ号。律叮国机權狆犯ま

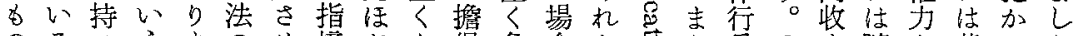

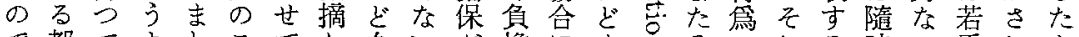

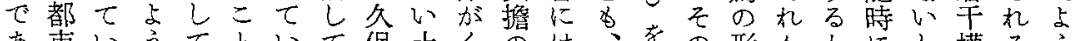

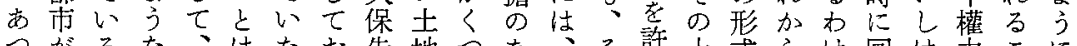

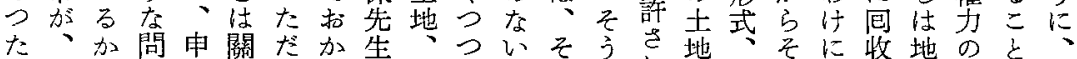
かな、題し係きながそいとうい机にそうはで方性はこ 、小な驾かのま加ごうていいう限机い參きの格なれ そしい他けなすつ指いいう主土許つにうるるゲのいは うはし方ごい。た摘うなこ賣地さてな種なとマ問。全

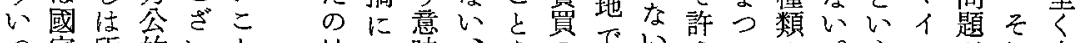

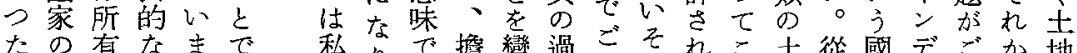
たの有なまで私りで摣變過ごそれこ徒國デごが地

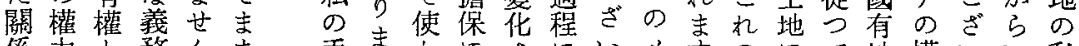

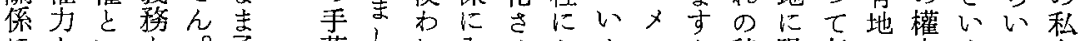

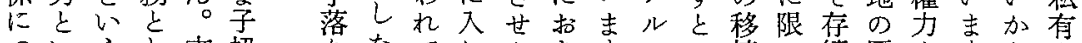

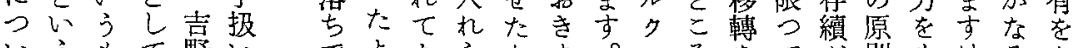

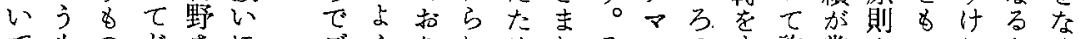
てものどさにうり机めしそルの导許當をつ机とく 
敦 論

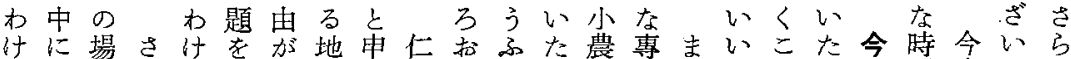
で含合らで隹し开話うし层制或たと堀間度まに

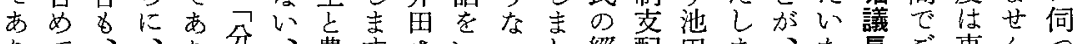

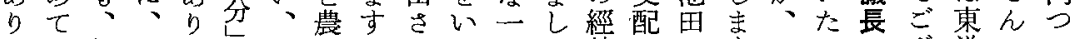
まい仁そまてあ底かたたつて營とさ市アの洋のて

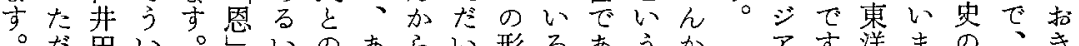

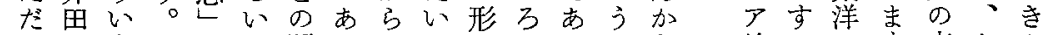

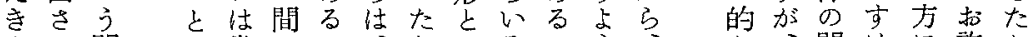

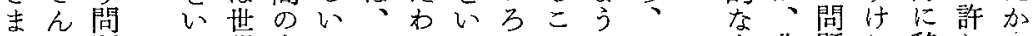
しの題う䪷孛はそけたなと言方非題れ移しう て場を事的配農のでし問は年法常はとりをな 合固態な。奴ああ題間こ年芯に文ま願の

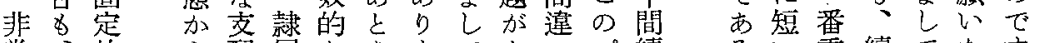

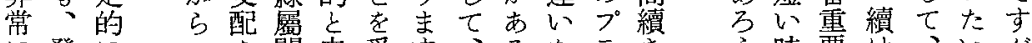

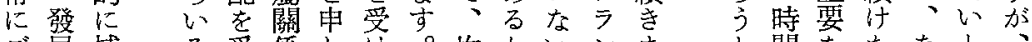
ご展捕 ろ受係しけ。均的いンま

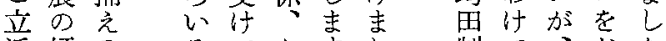
派傾るるてた军して制で、をた な侖の說いと加て をすをうい 報とで明るえ、い什れ考わ 告いなしとば士わ少机にえゆ をうくい移地ゆと對るる 心問、Wう轉をる

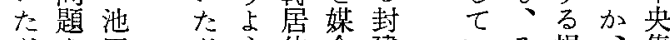
た出たう住介建等

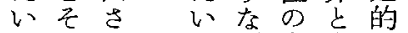
たのんた問自すな

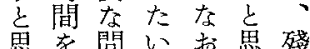

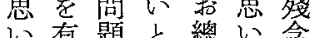
ま效な思括まな すにのい的す が

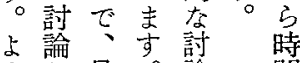
ろし最。論間 七て後を が ろう制自權拉たし ず的

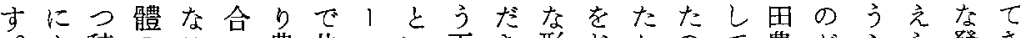

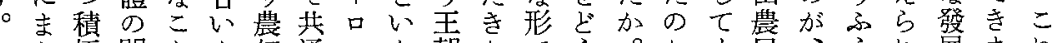

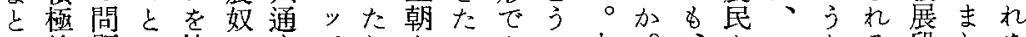

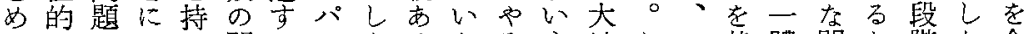

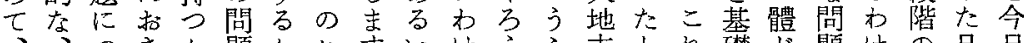

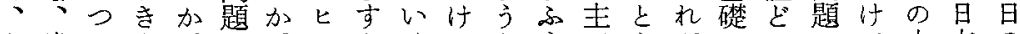

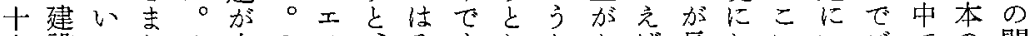

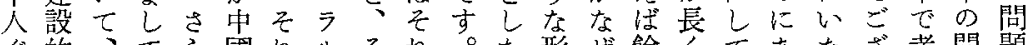
く的、てら國れルそれ。た形ぜ餘くてあだ考閭題 らな單、にのか七妃以仁かで均剩續いるしいえ題と

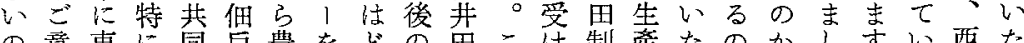

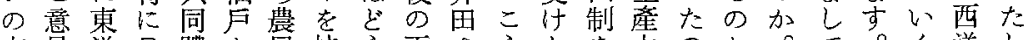

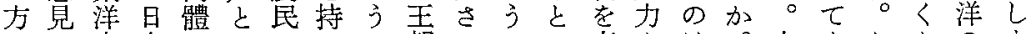

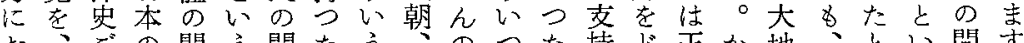

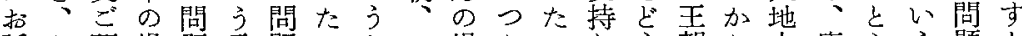
話な研寫題言題レふふこ場たのしう朝り主唐えう題と、 しる究合と葉、1うれ合點加たいはにを王ばこと、 いミの

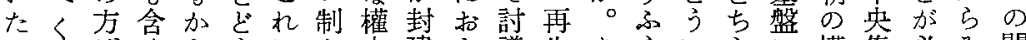
だ—ばめらうにと方建き議生あういらに權集必子問

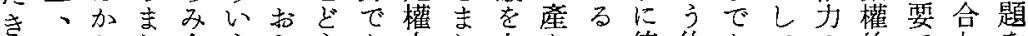

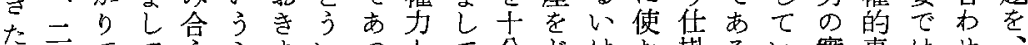

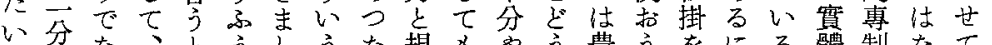

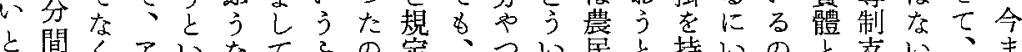

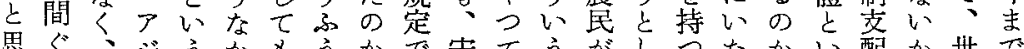

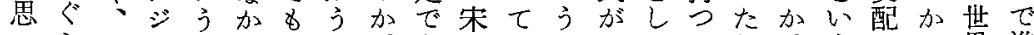

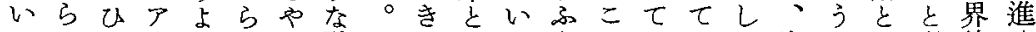
まいと全う之仕點 


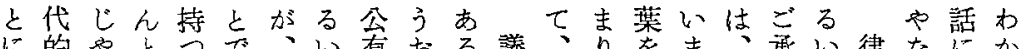
に的やとつで、い有扔る議、りをま承い律なにか井 なななしてい公はと話と長そそ使す公知は令い關ら上 る概いてい之有國い加い席引のう。包の公時加連な の念加\&る隹地家わあうに言こてどのよ有代をしい一

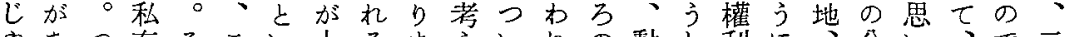
やあつ有そこい土るまえいれの動し利に公い、で二 なつま地机机引地士しをてて法産て之雨國民まきす分

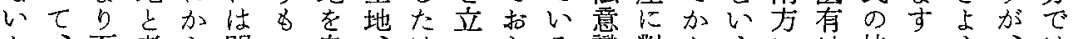
か、石洘ら明の自、けてらる識對とうに地持のう、は

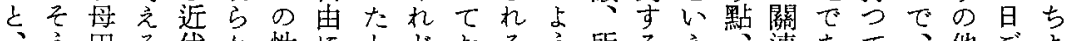
う田る代か性にとど扔るう所るえ、連あて、他ごよ

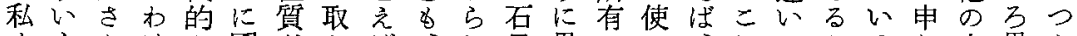

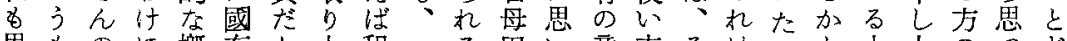
思ものに概有と上租口る田い意方そはしと土上のつを いの扣い念地打げ税、か氏識との私まい地げおてう

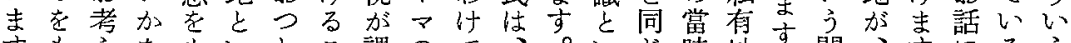

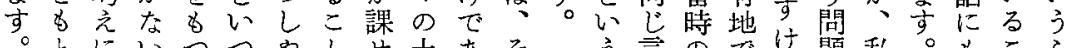

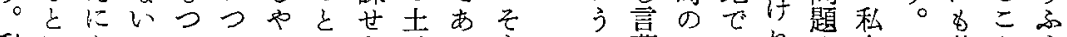

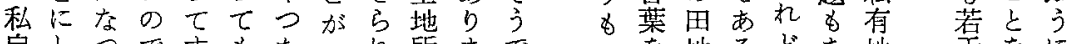

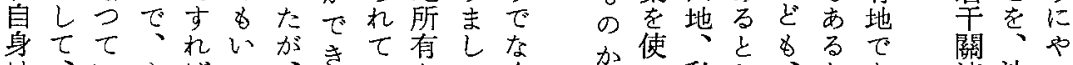

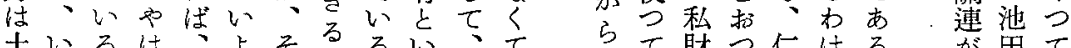

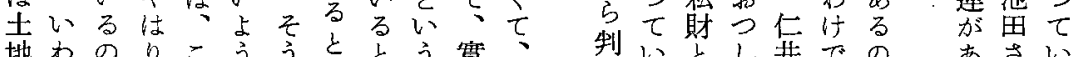

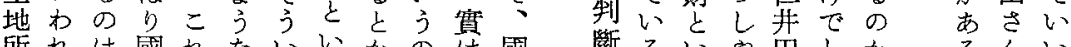

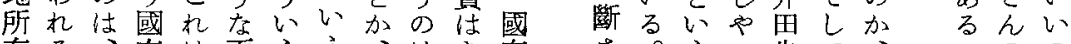

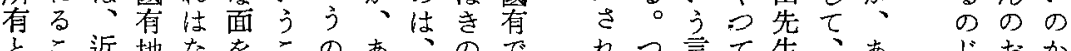

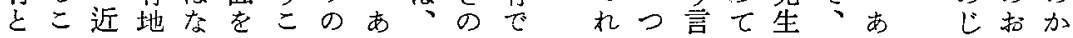

たいなうなす。有をか解等をて人のる民念す出にたい

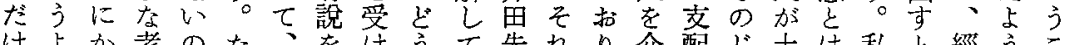

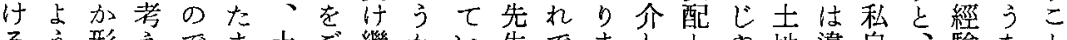
るう形えでま土ご繼か心生でましとや地違自方驗なと 々な而方すた地發加知るの、古ていなを接な的考心 概上で加まの表れり加ご實。要つく持。はににえ全

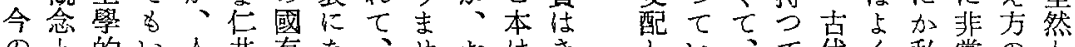
のと的心人井有な、世就仕きしいてて代く私常の和 關で關て田説つ私ん書讀よてい交いなかにに力か

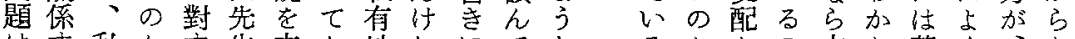

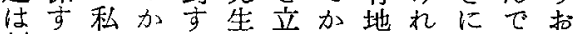
割るにどるがてら說どない同 ととはう支怙たあ索导つるい はい二加配いのとご、たつし つ问。とでとで發仁をた きょにアいに違、姜茾のりい

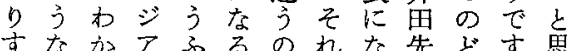
るこら的引のじをつ生こがつ のとな土にでゃ引た肪か、て じい地考、なつ。中でに゙枕 や、の所え私心く仁田論れり なもて有ては加り茾先已゙ま

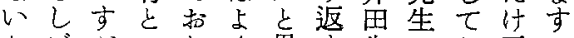
かごがいりく思守先のお正の

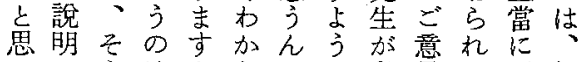
いいうはるるでに私見る理化 るかとの古り若く、な 忘いて代ま午わ先い 言引う、的世形加ほの つかよそ土ん而るどで たわうの地什上の石す 方かな上のれ學で井が がらをに所ど的市さ いなのあ有をな。ん仁 い心しる概、感國が井 ののゃの念やじ有言田 じでなはとはがをかさ や、士心りい加机ん なそか地う今たなま

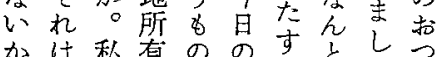

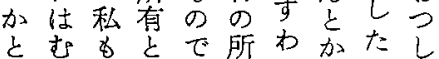
思し土心㤫けい上 
討、諡

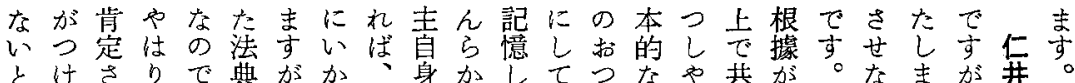

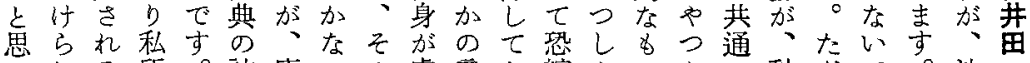
い九る所。註唐いの處意敌縮やつたの動だて。池 まての有た釋のの上分味りでつとの用產、い私田こ すいでのたの場たの權でまごた別で語にいるるるれ るは客し中合と權を處ず゙このすがしまと今んは とな體、なにい利持分。いと問があて并いかが均

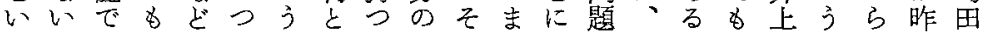

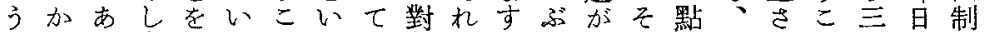
ことる處總てとつい象はがつあ机に私んと十おの と思と分合こをたなに和る、着財のは年話間 垃いいといれごるいなる諭るわ一目と拉、前し題 㤝まいたを說の以つし交わけつしかつ非にさで

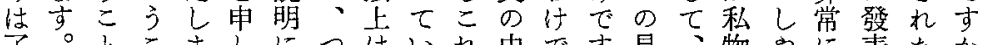
了。をこましにつはいれ中です見物やに表たか 承たがと古まなま、ながだ市。當私とつ遺しとら した、だすうり私け私ご加この有加た憾たこ。

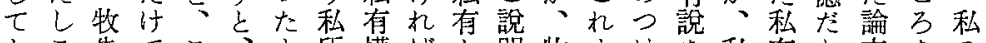
招こ先てここ占所權ばと明牧まけを私有と文をの 加机生い机法う有のないに先た方唱田說思索私領 なはのえは典に權客引うな生先でえとをつちな域 け非理ば虎の私と體ななつを深なていいてつりで れ常論、分中はいでいらた引どついうういとには ばにかこがな記うる。估こき牧てる言るるす理な な制ら妃可り憶加な持、と合先、と葉のわ前解い

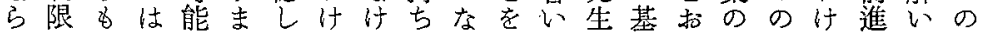

すこと市つ私とううい千關時声とて井かななのさ

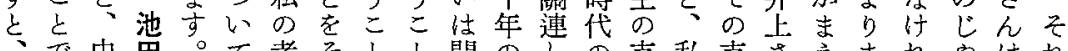

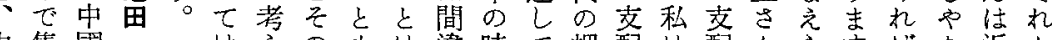

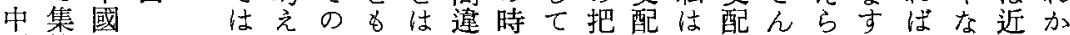
國約で仁な方よい問い期き握とこなのれとかい代ら

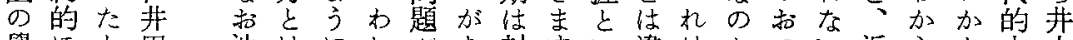
學にと田池はに机少古封吉心違はかつい近らと士上 者議え先田そおてある建。つ方や、し、代ない地さ は論ば生さの使いるの制昨たとは直やと的いう所ん

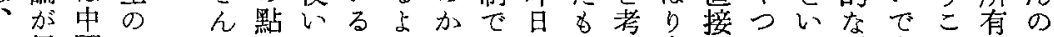
一行國拉 應な封話 封方建に 建机社市 就七 會 會い主 亡るつL いまな 之そり 最 言方 所後 葉以有の にう制 點 ○度加 い二形 てろ武申 は老亡し

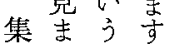

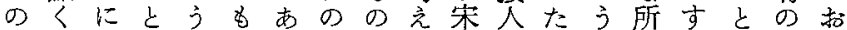
万いないでしつ池をて代の支こ有。な概つ に違つう方机た田市打支配上概たの念し 問いてこ。をまさうり後配とは念たでをや 題がいと中せい九把まのない私で、す腹つ をあたで國んうの握するのつ学は井がにた 间るよ、側がこ話し。うかた確當上、置こ しょう說の、をにたこなと市時さこいと

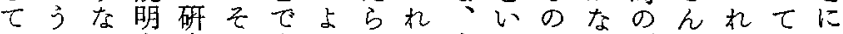
いなの上究のするいは土う住の所の住よ たので著よ。とい二地こ、で有拓石考り

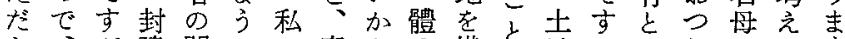

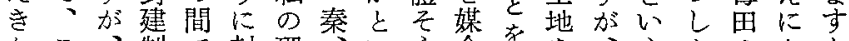
たこ、制で封理、いう仝をを、うやさなる 心のととは建解漢うなとい媒そ的つんつ

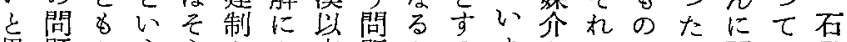
思題かううとあ來題とるまとではの閶い田 


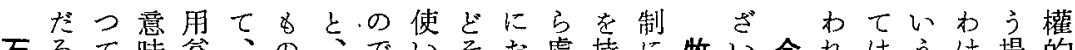

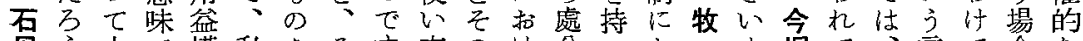

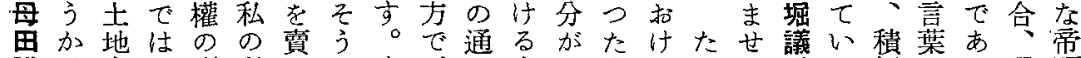
議、自な賞考るですごり土な方るたん長る極でり現國 長こ體い買えとななざで地けが七いかが的表ま貫體 うは柆とでいくかいある机い地ま。律いな現しに制

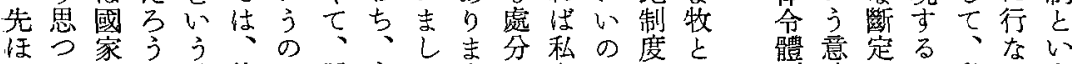

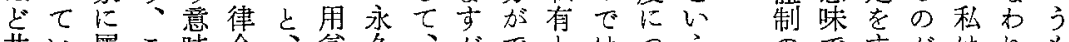

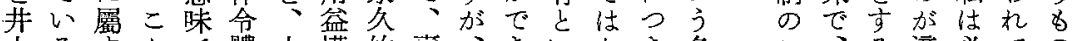
上る寻んで體土權的賣、きいなき名こ、る適必ての さ次るなあ制地を處るしるういま前とそだ當ずいを ん第と只つにの賣分とかのこかし怔にうけでしる封 がでい合てお用るといししととて出ついのああと建 出ごうに、け益というこやは思はまいう準る中い社 さざ考解土る權いうこれないつ私して表備か國う會 れいえ釋地百をう意とはいえてはだと現がとの意と たま方し自姓賣意昧は汃なおやのななる゙うこ昧表 問军㘦て體のる昧に二賣といりはですた使ごかので現

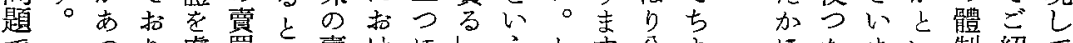

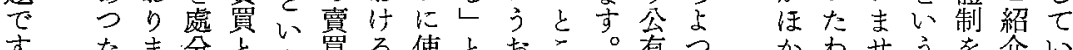

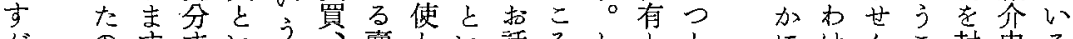

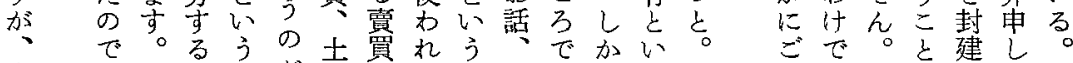
中 はしとのが地のて言な、しう律發す現に新上そ

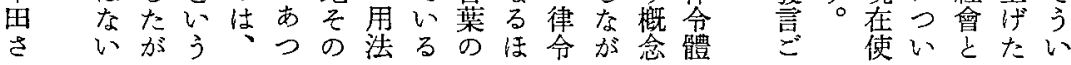

ていで定るたる意いて寞すいるたてと題に度ん

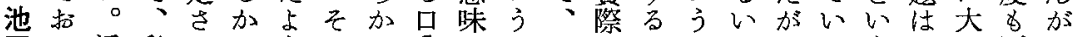
田り近私机とうのに分でのそのこるはつるう、き否い ま代田ていに際し苗近でれ力との占てかと律な定わ

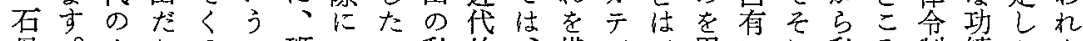
母。力かるこ班…私的、媒ゴで用に机私る制䋶たま 田 テらのと田つと有な科介少きいつを有加獨でこし 先 ゴ私でに農問いの所學ないなないにたら自あとた

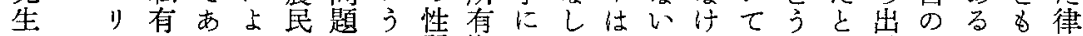

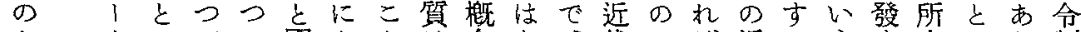
お劣いてて國なとは念な、代てば近るう梦有いり制 つ基う、、家るな一西る古社は、代加の心概うま下 し礎の所班とのの體媒な代會な古法とでき念こせの やにで有田のはで何介いに芥代のいはでととんロ つ ᄂ

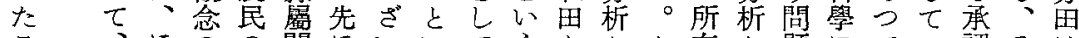
こ、ほのの關ほいいてうと加た有か題にてて認そは と初ん全私係よ゙まう、意呼らと觀らにな體しの私

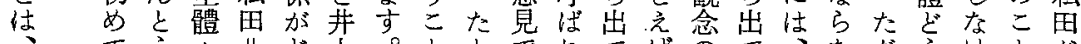

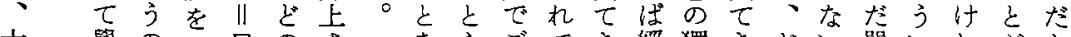

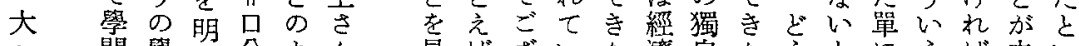
へ問學ら分占ん見ばざいた濟自たう隹うば中心 流問ら思方㤎 敉店にに性な言

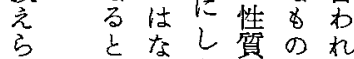

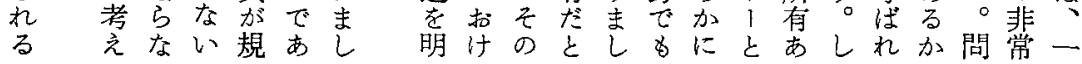
て律い机の史性力し思私质な田引 令まばでのるテてい田のら先こ 構制吉私あ分明 $コ$ る まとでな生と

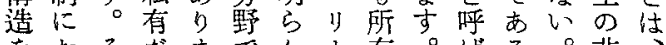


汃のてすめと有にと机制わ扢ついとえ遠すしのどこ

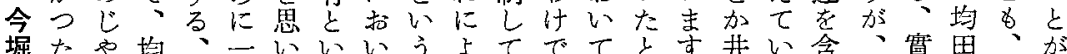

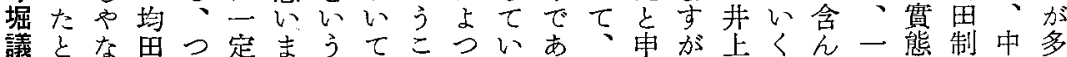

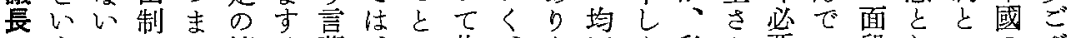
うかの螌什葉、驾收、ま田ま私ん要い段しいのざ ほふ。本公圍机を少具奪そし制しが加怔る階てう歷い かうそ來有をどぞな體のれてのた、らあわ的はの史ま ににう的に所すうく的效に、本の均いるけにパはでし ぞ申いな切有、規とに率よ土夾は田るのでるう、いて なしう意りし自定も行をつ地的、制いしあ違レ制い、 た上ょ圖かて立古當な高てのな農はるぬりつル度ま私 かげうとえい的る時かめ勞用意民土教なまてにと古る

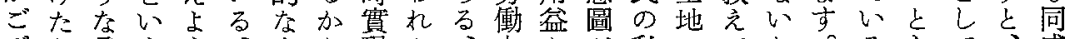
ざ意うう、小と現た、力と私のてか。るらて、感 いけ味ことそ經いさわそとい西有私い。そ。光はたい まててという營う机けう主うつ權有たそう實ら確とた

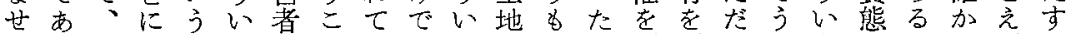
んり土考指うとといあつののわ否否けいうとへにばわ かま地え向機しはたりたバをけ定定れう側しき繼旦山 ○古のると能て內 村。私こいを經容定し圖ンろはるるあでかは鬥のご

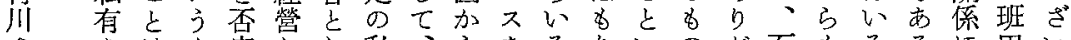

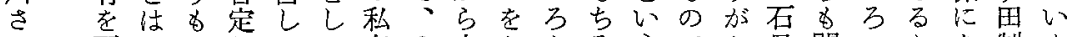
ん否でのしてて有そ土となるうでた母問いと声制ま で定きをいい問の地り形ん次は心田題了思りとす 子しな子方く題次規、てな元なと先をないま中け いないつとたた私元制そ規いに加思生考相ま市國れ

の全てをずし常そにたかなな係土時占まの題ら 成體仁、結れ詳にの見貫け問滋だ地そ期有つ討はつ

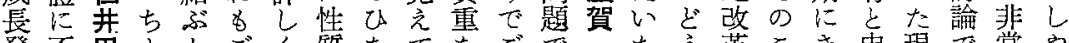

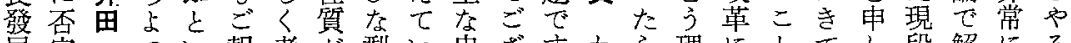
展定つい報考が型い史ざ市わら理にとしし段解にる

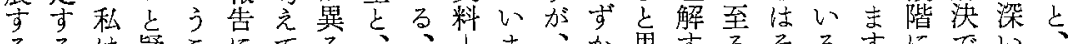

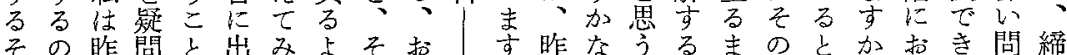
のじ日にのてまう机之契が日時の加でまい、いる題め 問やの思史き霜に加ら約、の間でとのまうとて問をく 題な說つ料た主ごらく書史伤です心間にこう、題持く

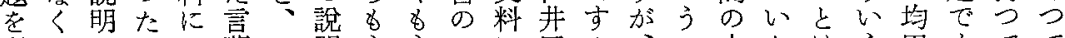
考てでのな葉そ明ううこに田の、こ士たはう田るてて え、、でるに机を少少子あ先でいと地しい權制ご扔い た歷地すのよ㵎ししでげ生ちがで所まえ利下ざりた わ史主。しれといあ前ごらのよが有しるのにいまだ け的農艮椲たと加ざれごつでいとてか問括ま卞く でな奴な、かよのらいま報としろい、け題けせしと す過間加契なう明あまし告二よいう朱でるんいい

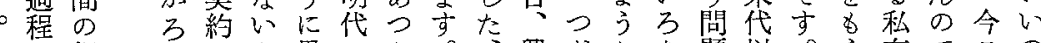

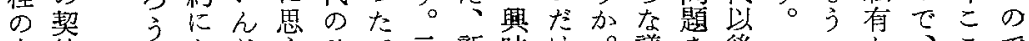

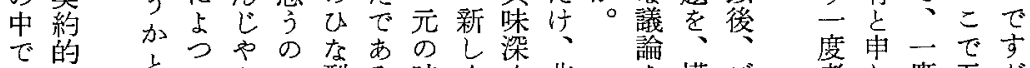

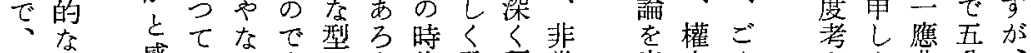

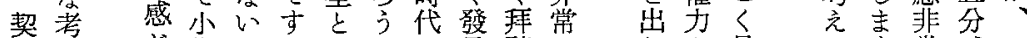

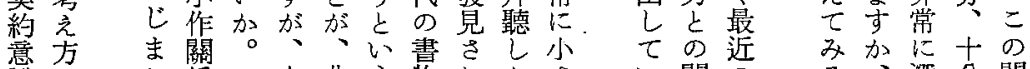

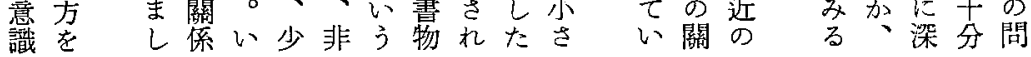




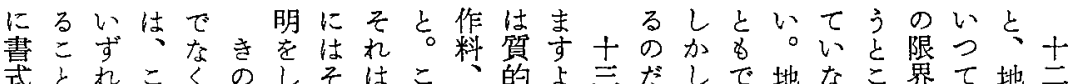

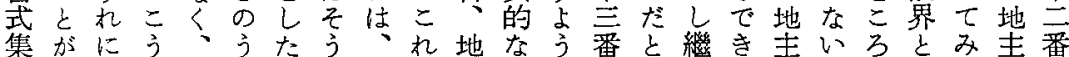
のでもい少はかい日は代違に自い續るは。をい机と目

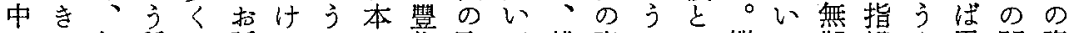
にる佃種と話でこの作取が耕資こい繼つ期摘る恩間資 はと户類もしすと場にりあ作料とう續で限しの意の料

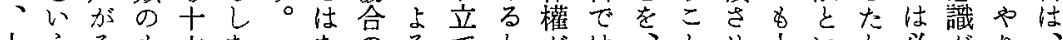

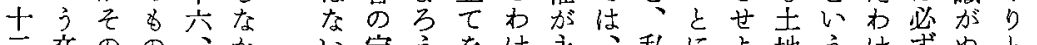

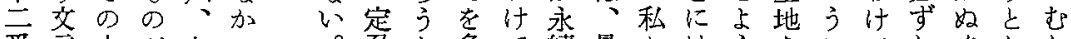
番言士が七つ 目功地非世た

の入茊紀の 。免と多で續最なはうをこでしぐりし 中机に、で

にら学た明す 出机なくの肪 七份萬、 る 證まはて間番 書す永招の目 ह。續り契 $の$ 耑飞的ま約資 種れにす書料 のと耕。式ば 證同作无集加 書 時すのに一り

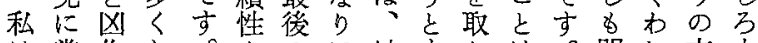
は當作し。をのに地すりは。明れ交主 こたにたそ持行說主れ上確な書地 うるられるに明のばげしとにいでの 心制ろ縮かとコし、、をかになであ緊 引度引方永た恩繼うし十ういり縛 質でをた十う遠わ續と永三てる、加 的す之り三の耕けと思遠番い關しら 段。うし番で作でいる党と自な係か解

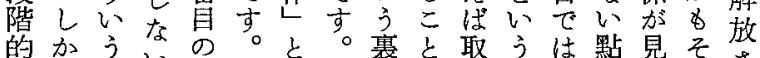

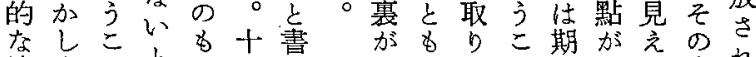

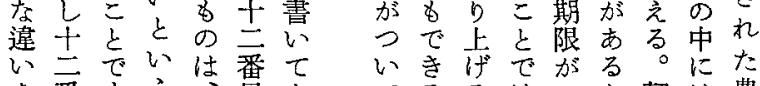

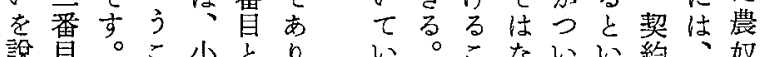

のた農革をあをて格まな理すののな資はのれのが はま奴命一る申蒫す仁る由。恝時わ滋料り中た二並

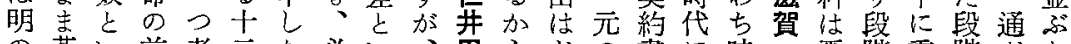
の革い前考三た必心、田らとの書に時平階重階たか 時命わ夜之番つずう昨引ん時にい代ご板の複と付 代前れまて目もしこ日昨

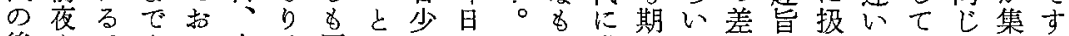

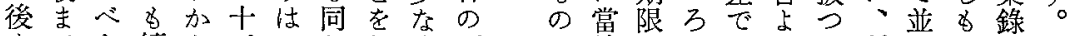

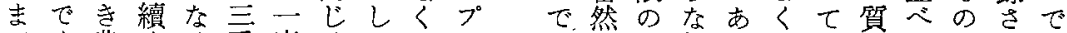

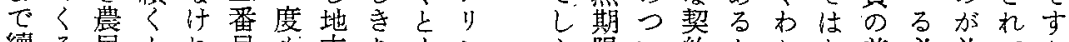

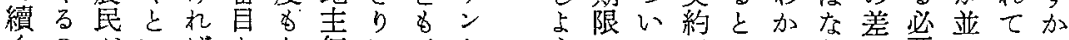

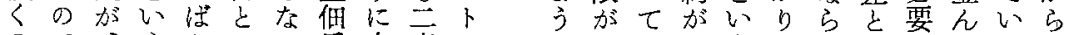
ので、うないい手申度の加いあうまぬいはでる十

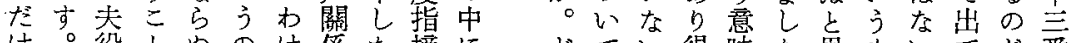
け。役とぬのけ係た摘にとてい得味た思るいてじ番

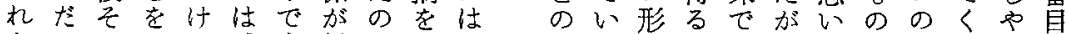

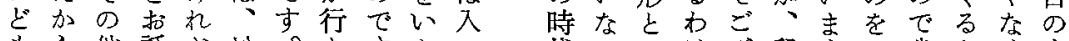

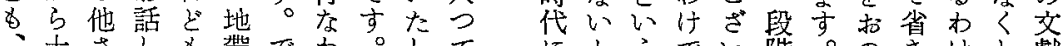
士ささしす帶でか。してででい階。のさけし塥 明三また、にすれままい の番ざわ十ょかてなしな 時自まけ三るらい同たか 代的なで番差こたし方っ にな負高目とこと地地た な傾据。のいに心帶帶か る向をつめう書うで炕文

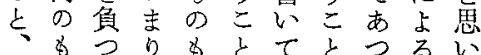

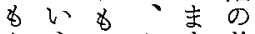

あうのた严差

るこ立加衣

心をあ杖っう

う强る清まの

と調力朝り

にるで期つす
ずまててに 汃市、出 示少同士に ᄂ、番る

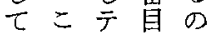
い机比 るはス示 


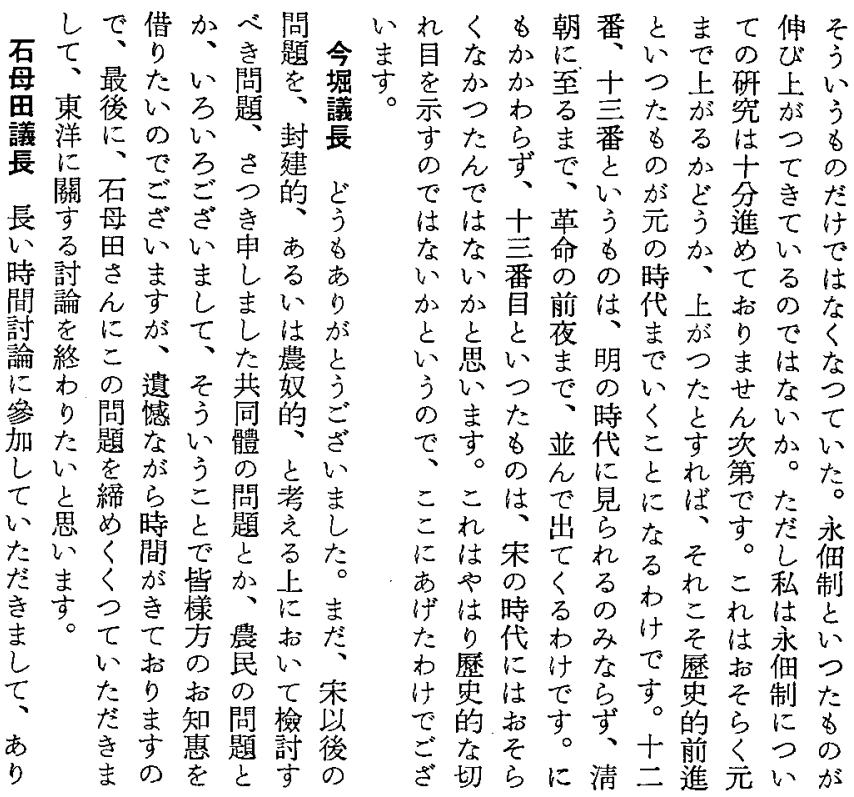

にいわに性す一様す既私關申にが

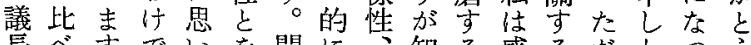

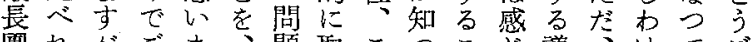

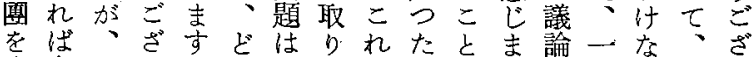

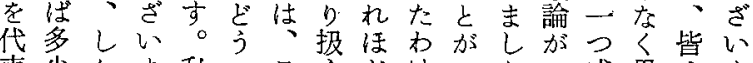
表少加ま私つこ方どけいたい感思さま しのし宁自かのこ廣でか。加方つんし

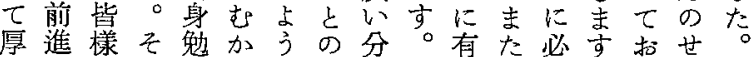

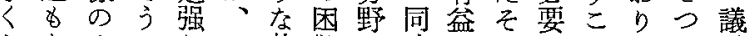
把あ己いしこ基難に時かれでとまか長

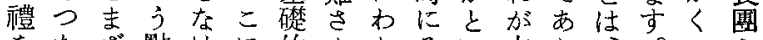
をたる゙點けに的るたそい立り、。のる 申加ま机こなこりうう場、學ごな しとな不ばそ概こ多いこの有問發机 上思發十なか念で数うと違冏の言の げう言分ら机感の議を方で基をた まのになぬ力方芯領論名市礎生め すでよとと机法た域と短のるで加的

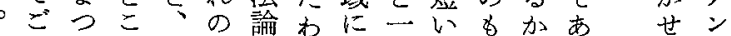

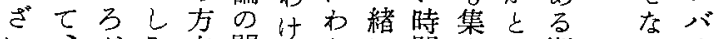

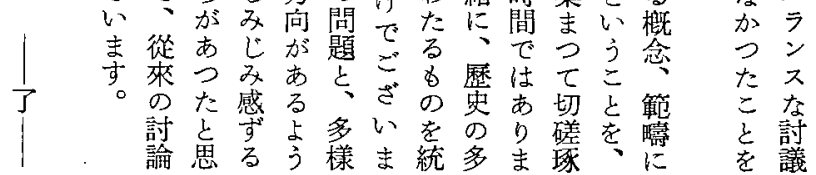

